
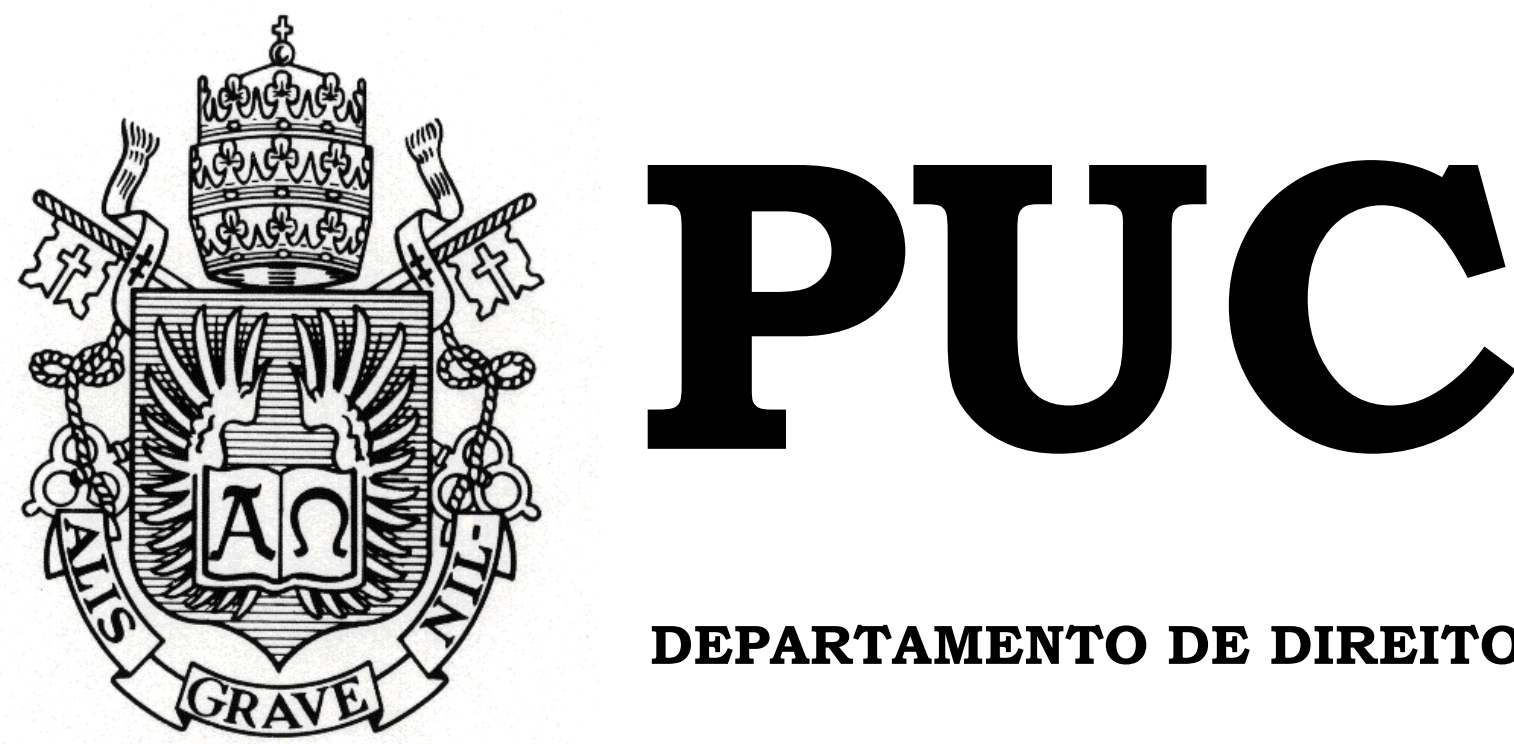

DEPARTAMENTO DE DIREITO

\title{
O ACOLHIMENTO INSTITUCIONAL NO ESTADO DO RIO DE JANEIRO NA PERSPECTIVA DO ADOLESCENTE E UM OLHAR RESTAURATIVO SOBRE AS MEDIDAS SOCIOEDUCATIVAS
}

CILAINE CRISTINA LOURENÇO DA SILVA

ORIENTADOR: CARLOS RAYMUNDO CARDOSO

\section{1}

PONTIFÍCIA UNIVERSIDADE CATÓLICA DO RIO DE JANEIRO

RUA MARQUÊS DE SÃO VICENTE, 225 - CEP 22453-900

RIO DE JANEIRO - BRASIL 


\title{
O ACOLHIMENTO INSTITUCIONAL NO ESTADO DO RIO DE JANEIRO NA PERSPECTIVA DO ADOLESCENTE E UM OLHAR RESTAURATIVO SOBRE AS MEDIDAS SOCIOEDUCATIVAS
}

\author{
por \\ CILAINE CRISTINA LOURENÇO DA SILVA
}

Monografia apresentada ao Departamento de Direito da Pontifícia Universidade Católica do Rio de Janeiro (PUC-Rio) como requisito parcial para a obtenção do título de Bacharel em Direito.

Orientador(a): CARLOS RAYMUNDO CARDOSO

2015.1 
Nunca vi cartão postal em que se destaque uma favela.

Só vejo paisagem muito linda e muito bela.

Quem vai pro exterior da favela sente saudade. O gringo vem aqui e não conhece a realidade. Vai pra Zona Sul pra conhecer água de coco. E pobre na favela, passando sufoco.

Trocaram a presidência, uma nova esperança. Sofri na tempestade, agora eu quero a bonança. O povo tem a força, só precisa descobrir.

Se eles lá não fazem nada, faremos tudo daqui. (Cidinho) 


\section{Agradecimentos}

A Deus, por todas as graças alcançadas.

A minha mãe e a minha madrinha do céu, por sempre terem iluminado meus caminhos.

A minha família, por todo o apoio e oração ao longo dessa trajetória, com carinho a minha mãe e irmã. Em especial ao meu pai, por sempre ter lutado por mim, único defeito é torcer pelo botafogo.

Ao Claudio de Azevedo Antunes Joffe, pela confiança.

Ao professor Carlos Raymundo, pelas excelentes aulas que despertaram minha paixão pelo direito penal e, como orientador, pelo suporte, paciência, disponibilidade, correções e incentivos.

Aos adolescentes das instituições e unidades visitadas, pela gentileza e confiança. Tenho certeza que um dia nos encontraremos em situações melhores.

A todos os defensores, técnicos, funcionários e estagiários da CDEDICA, pela importante contribuição nesse trabalho.

Às doutoras Márcia Fernandes e Eufrásia Souza, pela dedicação, paciência e disponibilidade.

À doutora Sylvia Ignes, pelo exemplo.

Ao futuro Juiz Federal Alexandre, pela atenção e contribuição. Ao Neylon, por possibilitar a visita a instituição de Rio Bonito.

Às pessoas que me receberam nas instituições e nas unidades, pela disponibilidade. 
As minhas irmãs de república, Gabi, Nani e kaury que sempre me incentivaram e são responsáveis por algumas das minhas melhores lembranças.

As minhas amigas de curso, Cleo Vieira e Ingrid Borges por terem tornado o caminho mais alegre.

As minhas amigas de curso, comida e fofoca, Aline Morato e Giselly Monteiro, por serem tão especiais na minha vida.

A minha amiga Ellen Mendonça, por estar ao meu lado até o último momento da realização desse trabalho. Você é uma amiga mais que especial.

Ao meu amigo Diogo, por toda ajuda.

Aos professores do departamento de direito, com carinho: Regina Coeli, Inês Rocumback, Maurício Rocha, Isabella Guerra, Rogério Nascimento e Leonardo Chaves pela confiança depositada em mim.

Aos funcionários do departamento de direito, por terem me salvado ao longo desses anos, em especial o Tião.

Ao Igor Fernandes, por sempre avisar que a aula seria no Leme.

Aos amigos do departamento de administração, pela melhor turma da faculdade.

Ao amigo Viktor Araújo, por ter me esperado. Não poderia perder essa oportunidade.

A todos os funcionários da PUC, pelo carinho, atenção e sorriso.

Ao Henry Douglas, Renato e Giuseppa Benedetti (in memoriam), vocês estarão sempre presentes no meu coração.

Aos meus professores do ensino médio, pela confiança depositada em mim. E a todos que direta e indiretamente contribuíram para a minha formação, o meu muito obrigada. 


\section{Resumo}

O presente trabalho tem o objetivo de analisar as violações de direitos das crianças e dos adolescentes nas instituições públicas de acolhimento do Rio de Janeiro demonstrando a coculpabilidade do Estado e da sociedade no ato infracional cometido pelos indivíduos que circulam entre as duas medidas, a protetiva e a socioeducativa. Para tanto, percorre o seguinte caminho: (i) aponta os principais motivos de institucionalização, em especial a violência doméstica e a negligência, e o perfil das instituições de acolhimento; (ii) apresenta os modelos das instituições no Brasil, desde o SAM às instituições de acolhimento. Aborda a importância do Movimento dos Meninos e Meninas de Rua na aprovação do Estatuto da Criança e do Adolescente; (iii) narra o estudo dos casos da Central de Triagem Taiguara e da Central de Acolhimento Ayrton Sena; (iv) procura, através dos depoimentos de adolescentes que passaram pelos modelos protetivo e socioeducativo de institucionalização, demonstrar a coculpabilidade do Estado e da sociedade no ato infracional e propor um olhar restaurativo sobre as medidas socioeducativas.

\section{Palavras-chave}

direito, criança, instituições de acolhimento, Meninos e Meninas de Rua, medida socioeducativa. 


\section{Sumário}

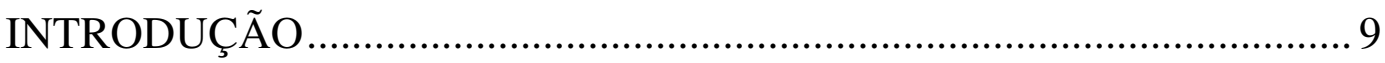

\section{AS CAUSAS DE ACOLHIMENTO INSTITUCIONAL E AS}

DENOMINADAS INSTITUIÇOES TOTAIS .......................................... 12

\subsection{A Negligência e a Violência Doméstica na Perspectiva do}

Acolhimento Institucional

1.2. Instituições de Acolhimento: Conceitos e Preconceitos sobre a

Institucionalização de Crianças e Adolescentes

2. DO SAM ÀS INSTITUIÇÕES DE ACOLHIMENTO. BREVE COMPARAÇÃO DOS MODELOS BRASILEIROS DE INSTITUCIONALIZAÇÃO E A IMPORTÂNCIA DO MOVIMENTO DOS MENINOS E MENINAS DE RUA NA APROVAÇÃO DO ESTATUTO DA CRIANÇA E DO ADOLESCENTE.

\section{ESTUDOS DOS CASOS DE TORTURA E DEMAIS}

VIOLAÇÕES DE DIREITOS NAS INSTITUIÇÕES PÚBLICAS

DE ACOLHIMENTO DE CRIANÇAS E ADOLESCENTES DO

MUNICÍPIO DO RIO DE JANEIRO.

3.1. A Tortura contra Crianças e Adolescentes no Ordenamento

Jurídico Brasileiro

3.2. Estudo de Caso da Central de Triagem Taiguara 52

3.3. Estudo de Caso do Centro de Acolhimento Ayrton Sena 55 
4. DA INSTITUIÇÃO DE ACOLHIMENTO AO

SOCIOEDUCATIVO: A APLICAÇÃO ANÁLOGA DO

PRINCÍPIO DA COCULPABILIDADE

4.1. A Culpabilidade, Inimputabilidade Biológica e a

Coculpabilidade no Ordenamento Jurídico Brasileiro 63

4.2. Aplicação Análoga do Princípio da Coculpabilidade às Medidas

Socioeducativas à Luz dos Casos Concretos e a Substituição da

Justiça Punitiva pela Justiça Restaurativa .72

5. CONSIDERAÇÕES FINAIS 84

6. BIBLIOGRAFIA 86

ANEXO 90 


\section{Lista De Siglas}

CAAC- Centro de Atendimento ao Adolescente e à Criança

CAPS - Centro de Atenção Psicossocial

CDEDICA - Coordenadoria de Defesa dos Direitos da Criança e do Adolescente

CF/88 - Constituição Federal de 1988

CONANDA - Conselho Nacional dos Direitos da Criança e do Adolescente

CREAS - Centro de Referência Especializado de Assistência Social

DCAV - Delegacia da Criança e Adolescente Vítima

DPCA - Delegacia de Proteção à Criança e ao Adolescente

DST's - Doenças Sexualmente Transmissíveis

ECA - Estatuto da Criança e do Adolescente

FEBEM - Fundação de Bem-Estar do Menor

FEEM - Fundação Estadual de Educação do Menor

FLUBEM - Fundação Fluminense de Bem-Estar do Menor

FUNABEM - Fundação Nacional do Bem-Estar do Menor

IML - Instituto Médico Legal

ONU - Organização das Nações Unidas

PNBEM - Política Nacional de Bem-Estar do Menor

PSF - Programa de Saúde Familiar

SAM - Serviço de Atendimento dos Menores

SISNAN - Sistema de Informação de Agravos de Notificação

STF - Supremo Tribunal Federal

STJ - Superior Tribunal de Justiça

SUAS - Sistema Único de Assistência Social

SUS - Sistema Único de Saúde

SINEATE - Serviço de Integração de Entidades de Acolhimento 


\section{INTRODUÇÃO}

O presente estudo tem como objeto a análise das violações de direitos das crianças e dos adolescentes nas instituições públicas de acolhimento do Rio de Janeiro e a coculpabilidade do Estado e da sociedade pelos atos infracionais cometidos pelos adolescentes que estiveram no acolhimento institucional sob essas condições. Após a análise dos casos concretos é proposto o direito restaurativo como um novo paradigma para as medidas socioeducativas.

No Brasil é cultural a institucionalização de crianças e adolescentes. Existe uma carência na implementação de políticas públicas voltadas para a família, uma vez que a extrema pobreza é um fator significativo nesse processo. A retirada de crianças da convivência familiar, muitas vezes, é realizada tendo o paradigma da classe média. Não obstante, em tantos outros casos, essa se faz necessária. Dessa forma, há um contexto complexo de questões a serem analisadas.

A situação é agravada pelo Judiciário ao criar entraves, não previstos em lei, ao processo de adoção, como a exigência de idade máxima aos adotantes ${ }^{1}$. A obediência cega às filas de adoção, tão levantada pelo Ministério Público, também é responsável por impedir o direito ao afeto de muitas crianças e adolescentes. Tais fatores contribuem para maior institucionalização. Nesse sentido, o STJ entende que o formalismo da fila de adoção não pode se sobrepor ao melhor interesse da criança. ${ }^{2}$

Observadas a existência e a necessidade da instituição de acolhimento é proposta a sua retirada do campo da marginalização. O acolhimento institucional é importante no desenvolvimento de crianças e

\footnotetext{
${ }^{1}$ Processo no 0002939-07.2012.8.19.0202-Parecer Psicológico/Requerentes: J e R.G.

2 BRASIL. STJ, Habeas Corpus no 250.203 SP. Relator. Ministro Ricardo Villas Boas Cueva. Julgado em 07 Ago.2012. Disponível em: Acesso em: 05 junho 2015.
} 
adolescentes, seja por um período curto, médio ou longo de suas vidas. Com esse propósito, é discutido o problema das instituições totais como espaços de exclusão, transformados em depósitos de crianças e adolescentes pobres.

O direito é um permanente conflito entre a letra da lei e sua eficácia. Embora a institucionalização no Brasil tenha mudado o nome, a perspectiva constitucional e as diretrizes, é possível reconhecer a continuidade de muitas falhas no sistema. As continuidades se sobressaem às rupturas, de forma que se observada uma narrativa, sem determinar a data, o leitor terá dúvidas se é referente ao SAM, em 1950, ou a alguma instituição de acolhimento, nos dias atuais.

Nesse sentido, o trabalho pretende mostrar quem são os adolescentes em medida protetiva de acolhimento institucional e como são as instituições públicas de acolhimento do Rio de Janeiro, assim como, a história dessas instituiçõos, desde o SAM. Os adolescentes, principalmente os que transitam entre a instituição de acolhimento, a rua e a unidade de cumprimento de medida socioeducativa, apontam suas perspectivas, histórias e preocupações.

Com esse escopo, foram ouvidas crianças e adolescentes em medida protetiva e, adolescentes em medida socioeducativa, assim como as equipes técnicas e demais funcionários envolvidos nesse contexto. Para esse objetivo, foram feitas visitas às instituições públicas de acolhimento: Central de Triagem Carioca (município do Rio de Janeiro); Central de Triagem Taiguara (município do Rio de Janeiro); Casa da Criança (município de Rio Bonito); Educandário Professor Almir Ribeiro Madeira (município de Niterói), além de visita domiciliar, em Madureira, a um casal candidato a adoção.

Com o propósito de desmistificar os cenários apresentados nas novelas e filmes, são apresentados estudos de casos concretos apontando a tortura e demais violações de direitos das crianças e dos adolescentes nas instituições de acolhimento do Município do Rio de Janeiro. Os casos são 
da Central de Triagem Taiguara e da Central de Acolhimento Ayrton Sena. Com esse propósito foram feitas pesquisas aos autos das ações civis públicas, entrevistas aos defensores responsáveis pelos casos, assim como, levantamento dos inquéritos policiais nas delegacias e no Ministério Público.

Buscando analisar as causas de institucionalização total foram realizadas visitas às unidades de internação: Educandário Santo Expedito (Bangu), no qual foi realizado estágio pelo período de 6 meses, Santos Dumont (Ilha do Governador), Dom Bosco (Ilha do Governador). Nessas unidades foram entrevistados adolescentes que vieram de instituições públicas de acolhimento. Aconteceu algo inesperado, nesse sentido. Os adolescentes, aleatoriamente escolhidos, tinham passado pelas instituições de acolhimento apontadas como problemáticas no trabalho.

No cenário de exclusão, o adolescente se desenvolve recebendo como estímulo apenas a violência e a invisibilidade. Descontente, evade a instituição e na rua pratica o ato infracional. Em razão disso sofre uma medida socioeducativa muito semelhante à pena estabelecida pela execução penal.

Dessa forma, é questionada a contradição do sistema que busca através do controle e da repressão, numa unidade de medida socioeducativa, a ressocialização do adolescente nunca inserido na cultura social. Para esses indivíduos as medidas socioeducativas apenas representam um processo de continuidade, pois estão adaptados a existência dentro dos muros.

Nesse sentido, é proposta a justiça restaurativa como um novo paradigma para as medidas socioeducativas, visto a ineficácia do modelo repressivo atual, responsável pela reincidência. O direito restaurativo é uma forma de conciliação da sociedade com o adolescente, além da reparação dos danos diretos e indiretos causados ao ofendido e reflexão do ofensor. Através dela, a comunidade é convidada a trabalhar a sua coculpabilidade no processo de marginalização do adolescente e contribuir para a sua restauração social. 


\section{AS CAUSAS DE ACOLHIMENTO INSTITUCIONAL E AS DENOMINADAS INSTITUIÇOES TOTAIS}

Descobrir o que liberta o sol

Que faz buraco

Furação do escuro, escuro, escura

Esquecer ao menos uma noite

O medo, o mal real

Que te segura.

(O Rappa)

\subsection{A Negligência e a Violência Doméstica na Perspectiva do Acolhimento Institucional}

Um estudo realizado pelo Conselho Nacional do Ministério Público, sobre institucionalização de crianças no Brasil apontou como os principais motivos para o acolhimento institucional, a negligência dos pais ou responsáveis (80\%), dependência química (80\%), abandono dos pais e/ou responsáveis (77\%), violência doméstica (aproximadamente 60\%); abuso sexual praticado pelos pais e/ou responsável (aproximadamente 45\%). Como muitas vezes são apontadas diversas causas combinadas para o acolhimento, o somatório ultrapassa $100 \% .^{3}$

Será abordado, neste capítulo, a negligência e a violência doméstica como questões relevantes na discussão da institucionalização de crianças e adolescentes no país. A escolha por essas duas causas se deve ao fato de serem os motivos que envolvem maior complexidade, em razão dos elevados índices, da amplitude dos conceitos e consequências.

A primeira questão a ser levantada para a interpretação dos dados é a definição de negligência. O Estatuto da Criança e do Adolescente prevê, em seu artigo $5^{\circ}$, que nenhuma criança será objeto de negligência. Não

\footnotetext{
${ }^{3}$ Disponível em: http://www.cnmp.gov.br/portal/images/stories/Destaques/Publicacoes/Res 71_VOLUME_1_WE B.PDF, p. Acesso em 20 mai 2015.
} 
obstante, o mesmo diploma legal, em seu artigo 87, III, determina que haverá serviço especial de prevenção e atendimento médico e psicossocial às crianças e adolescentes vítimas de negligência. Contudo, não há no texto legal qualquer definição nesse sentido.

O estudo adotou o conceito do Ministério da Saúde que define como negligência as omissões dos adultos (pais ou outros responsáveis pela criança ou adolescente, inclusive institucionais), ao deixarem de prover as necessidades básicas para o desenvolvimento físico, emocional e social de crianças e adolescentes ${ }^{4}$. Inclui a privação de medicamentos; a falta de atendimento à saúde e à educação; o descuido com a higiene; a falta de estímulo, de proteção de condições climáticas (frio, calor); de condições para a frequência à escola e a falta de atenção necessária para o desenvolvimento físico, moral e espiritual. ${ }^{5} \mathrm{O}$ abandono é a forma mais grave de negligência. A negligência não está vinculada às circunstâncias de pobreza, podendo ocorrer em casos em que recursos razoáveis estão disponíveis para a família ou o responsável. Segundo Guerra, a negligência se caracterizaria quando os pais ou responsáveis falham, tendo o controle da situação, em alimentar, vestir adequadamente seus filhos, etc. ${ }^{6}$

Em consulta à jurisprudência do Tribunal de Justiça do Rio de janeiro, limitada as decisões do ano de 2015, até o dia 05 de maio, foi possível verificar a utilização do termo negligência em 3 situações distintas. $\mathrm{Na}$ apelação 0010706-33.2011.8.19.0202, ${ }^{7}$ de relatoria do desembargador Eduardo Gusmão Alves de Brito Neto, o termo negligência foi utilizado

\footnotetext{
${ }^{4}$ BRASIL. Ministério da Saúde. Violência faz mal à saúde. Brasília: Ministério da Saúde, 2004. 296 p.44-46

${ }_{6}^{5}$ Ibid.

${ }^{6}$ AZEVEDO e Guerra apud AMARO, Sarita. Crianças vítimas da violência: das sombras do sofrimento à genealogia da resistência. Uma nova teoria científica. Porto Alegre: AGE/EDIPURS, 2003.p. 33.

${ }^{7}$ APELAÇÃO 0010706-33.2011.8.19.0202 Assunto: Adoção Nacional / Seção Cível / DIREITO DA CRIANÇA E DO ADOLESCENTE Origem: MADUREIRA REGIONAL 1 VARA INF JUV IDO Ação: 0010706-33.2011.8.19.0202 Protocolo: 3204/2014.00630032 - APELANTE: SIGILOSO APELANTE: SIGILOSO ADVOGADO: DEFENSOR PÚBLICO OAB/DP-000001 APELADO: SIGILOSO APELADO: SIGILOSO ADVOGADO: ROSIMAR ALVES MILANES PEREIRA OAB/RJ-144067 INTERESSADO: SIGILOSO. Relator: DES. EDUARDO GUSMAO ALVES DE BRITO NETO Funciona: Ministério Público e Defensoria Pública TEXTO: Por unanimidade de votos, manteve-se a sentença / decisão. Presente pelo Ministério Público a Dra. Maria Amelia Barreto Peixoto.
} 
como forma de submissão de criança à situação de risco. $\mathrm{Na}$ apelação 0210752-59.2011.8.19.0001 ${ }^{8}$, de relatoria do desembargador Marco Antonio Ibrahim, negligência foi definida como a ausência de imposição, por parte dos genitores, aos filhos, do dever de frequentar a escola, fato esse, que ensejou a reprovação dos menores. Na apelação 000166190.2011.8.19.0012 ${ }^{9}$, de relatoria do desembargador Carlos de Azeredo de Araújo, por sua vez, a negligência foi entendida como descumprimento dos deveres inerentes ao poder familiar, por parte da genitora, que não impediu que seu companheiro abusasse sexualmente de ambas as filhas menores.

Considerando a abstração do conceito, o termo negligência acaba sendo utilizado como motivo genérico para a retirada de crianças e adolescentes da convivência familiar e comunitária e colocação em instituições de acolhimento. Retira-se da convivência familiar, por negligência, tendo como modelo o padrão de vida da classe média. Essa questão foi frisada pelos estudiosos da psicologia e do serviço social durante a pesquisa de campo. Tal fato ocorre em razão da cultura brasileira de institucionalização. Conforme destaca Irenne Rizzini, há uma intervenção do Estado sobre as famílias pobres, acusando-as de incapazes na educação de seus filhos. ${ }^{10}$ Por outro lado, em muitos casos concretos, trata-se de uma necessidade.

\footnotetext{
8 APELAÇÃO 0210752-59.2011.8.19.0001 Assunto: Medidas Pertinentes Aos Pais Ou Responsável / Seção Cível / DIREITO DA CRIANÇA E DO ADOLESCENTE Origem: CAPITAL VARA DA INF JUV IDO Ação: 0210752-59.2011.8.19.0001 Protocolo: 3204/2014.00566294 - APELANTE: MINISTERIO PUBLICO DO ESTADO DO RIO DE JANEIRO APELADO: VANDA CONCEIÇÃO DOS SANTOS APELADO: ROQUE CARLOS DOS SANTOS ADVOGADO: DEFENSOR PÚBLICO OAB/DP-000001 Relator: DES. MARCO ANTONIO IBRAHIM Funciona: Ministério Público e Defensoria Pública.

9 APELAÇÃO 0001661-90.2011.8.19.0012 Assunto: Medidas Pertinentes Aos Pais Ou Responsável / Seção Cível / DIREITO DA CRIANÇA E DO ADOLESCENTE Origem: CACHOEIRAS DE MACACU 1 VARA Ação: 0001661-90.2011.8.19.0012 Protocolo: 3204/2014.00411315 - APELANTE: SIGILOSO ADVOGADO: DEFENSOR PÚBLICO OAB/DP-000001 APELADO: SIGILOSO INTERESSADO: SIGILOSO INTERESSADO: SIGILOSO Relator: DES. CARLOS AZEREDO DE ARAUJO Funciona: Ministério Público e Defensoria Pública TEXTO: POR UNANIMIDADE, NEGOU-SE PROVIMENTO AO RECURSO, NOS TERMOS DO VOTO DO DES. RELATOR.

${ }^{10}$ RIZZINI, Irene. A institucionalização de crianças no Brasil: percurso histórico e desafios do presente in Irene Rizzini, Irma Rizzini. - Rio de Janeiro: Ed. PUC-Rio; São Paulo : Loyola, 2004, pag. 70.
} 
Outra causa elevada, nos índices de institucionalização de crianças e adolescentes, com grandes reflexos na vida do institucionalizado, é a violência doméstica. Considera-se violência, para os fins abordados neste capítulo, a violência estrutural, conforme conceito de Boulding:

$\mathrm{O}$ conceito de violência estrutural que oferece um marco à violência do comportamento se aplica tanto às estruturas organizadas e institucionalizadas da família como aos sistemas econômicos, culturais e políticos que conduzem à opressão de determinadas pessoas a quem se negam vantagens da sociedade, tornando-as mais vulneráveis ao sofrimento e à morte. Essas estruturas determinam igualmente as práticas de socialização que levam os indivíduos a aceitarem ou a infligirem sofrimentos [a outros] de acordo com o papel que desempenham. ${ }^{11}$

A violência doméstica contra a criança e o adolescente pode ser definida como uma violência estrutural, no âmbito familiar, que nega a esses indivíduos a condição de pessoa em situação de desenvolvimento. Tal fato se deve a coisificação da infância, caracterizando violação ao princípio constitucional da dignidade humana, positivado no $\operatorname{artigo} 1^{\circ}$ da Constituição Federal, conforme ensina Ingo Sarlet na fórmula desenvolvida por Gunter During:

Para quem (na esteira da concepção Kantiana) a dignidade da pessoa humana poderia ser considerada atingida sempre que a pessoa concreta (o indivíduo) fosse rebaixada a objeto, a mero instrumento, tratada como uma coisa, em outras palavras, sempre que a pessoa venha a ser descaracterizada como sujeito de direitos. $^{12}$

O estudo da violência que afeta a população infanto-juvenil envolve uma série de fatores. Um aspecto relevante é o grau de vulnerabilidade socioeconômica das famílias excluídas da rede de consumo. A carência de recursos, a falta de espaço físico na casa, responsável por violar a privacidade, o estresse, provocado pela combinação dessas questões; são vistos como fatores de risco, principalmente, aos hipervulneráveis.

Contudo, definir o aspecto socioeconômico como único ou principal motivo dessa situação de violação de direitos, no ambiente familiar, além de

\footnotetext{
${ }^{11}$ Boulding apud CRUZ NETO, 1981, p.38.

12 SARLET, Ingo, Dimensões da Dignidade-Ensaios de Filosofia do Direito e Direito Constitucional. Ed. Livraria do Advogado. pp. 33-34.
} 
superficial é falacioso. Nesse sentido, Amaro enumera uma série de fatores que influenciam a vitimização do público infanto-juvenil, tais como: histórico de violência doméstica por parte dos adultos, problemas psicológicos, dependência química, despreparo para o exercício do poder familiar; autoritarismo como forma de educação e outros. Esses fatores podem ser apresentados de forma isolada ou combinada, num arranjo familiar. $^{13}$

Tratando do tema, após o caso Bernardo, menino de 11 anos, assassinado pela madrasta, que sofreu inúmeras violências, físicas e psicológicas, dentro do espaço familiar e foi, pessoalmente, buscar ajuda do Judiciário não obtendo êxito, foi aprovada a Lei 13.010/2014, também conhecida como Lei da Palmada ou Lei Menino Bernardo.

Essa legislação é apontada por parcela da doutrina, como o Nucci, de demagoga e midiática. Segundo o autor, seu texto vago e de impossível aplicação tem o propósito de iludir a sociedade que espera a eficácia das medidas de proteção à infância. ${ }^{14}$ Maria Berenice, por sua vez, destaca que, sem prejuízo de questões negativas, tais como a ausência de imposição coercitiva e de previsão para a violência psicológica, a lei teve o mérito de acabar com a permissão que havia no Código Civil para que os pais castigassem seus filhos moderadamente $(\mathrm{CC}, 1638, \mathrm{I}){ }^{15}$

O menino Bernardo buscou o auxílio da justiça. Entretanto, faltou alguém que agisse em prol de seus interesses, o curador especial. Nesse âmbito, destaca-se a discussão a respeito da curadoria especial. O Ministério Público e a Defensoria Pública travam uma batalha judicial acerca dessa competência. A atuação da Defensoria está pautada no princípio da proteção integral (CF. art. 227) e na lei orgânica da defensoria (LC 80/94, art. $4^{\circ}, \mathrm{XVI}$ ), sendo, portanto, sua inclusão na lide, na forma de

\footnotetext{
${ }^{13}$ AMARO, Sarita. Crianças vítimas da violência: das sombras do sofrimento à genealogia da resistência. Uma nova teoria científica. Porto Alegre: AGE/EDIPURS, 2003.

14 NUCCI, Guilherme. Lei da Palmada: Outra Demagogia. Disponível em: http://www.guilhermenucci.com.br. Acesso em 10 mai 2015.

15 DIAS, Berenice Maria. Lei da Palmada? Lei Menino Bernardo? . Disponível em: http://www.mariaberenice.com.br. Acesso em 15 mai 2015.
} 
curadora especial ou assistente inominada, necessária nas demandas em que crianças e adolescentes são partes (ECA, art. 142 c/c CPC art. 9, I e Súmula TJRJ 235).

Ressalta-se a necessidade da atuação da Defensoria na qualidade de curadora especial quando os interesses das crianças e dos adolescentes se colidem com os de seus responsáveis, buscando zelar pelos interesses dos primeiros, conforme o ocorrido no caso Bernardo. Nesse sentido entendeu a ministra do STJ Nancy Andrighi, no julgamento do AgRg no AgRg no AREsp $298526 /$ RJ. $^{16}$

Entretanto a jurisprudência não é pacífica, em recurso interposto pelo Ministério Público contra a decisão proferida pelo TJRJ, a terceira turma do STJ entendeu desnecessária a nomeação da Defensoria na qualidade de curadora especial $^{17}$. Segundo a decisão, cabia ao Ministério Público e não à

16 AgRg no AgRg no AREsp 298526 / RJ AGRAVO REGIMENTAL NO AGRAVO REGIMENTAL NO AGRAVO EM RECURSO ESPECIAL 2013/0041292-7 Relator(a)Ministra NANCY ANDRIGHI (1118) Órgão Julgador T3 - TERCEIRA TURMA Data do Julgamento 10/06/2014 Ementa RECURSO ESPECIAL. AGRAVO REGIMENTAL. PROCESSO CIVIL E DIREITOS DA CRIANÇA E DO ADOLESCENTE. AÇÃO DE DESTITUIÇÃO DO PÁTRIO PODER. NOMEAÇÃO DA DEFENSORIA PÚBLICA COMO CURADORA ESPECIAL DO INCAPAZ. POSSIBILIDADE. CONFLITO DE INTERESSES ENTRE A CRIANÇA E SUA GENITORA. ARTIGOS ANALISADOS: $9^{\circ}$, I, CPC e 142, PARÁGRAFO ÚNICO, ECA. 1.Ação de destituição do pátrio poder ajuizada pelo Ministério Público do Estado do Rio de Janeiro, da qual foi extraído o presente recurso especial, concluso ao Gabinete em 06/03/2013. 2.Discute-se a possibilidade de nomeação da Defensoria Pública como curadora especial de incapaz em ação de acolhimento institucional movida pelo Ministério Público. 3.Verificado o conflito de interesses entre a criança e sua genitora, impõe-se a nomeação da Defensoria Pública como curadora especial, nos termos do art. $9^{\circ}$, I, CPC e art. 142, parágrafo único, ECA. 4.A Defensoria Pública, no exercício da curadoria especial, desempenha apenas e tão somente uma função processual de representação do menor em juízo, sem qualquer obstrução às atividades institucionais do Ministério Público, o qual exerce seu mister de representação não apenas em caráter endoprocessual mas sim no interesse de toda sociedade. 5.A parte agravante não trouxe, nas razões do agravo regimental, argumentos aptos a modificar a decisão 6 agravada, que deve ser mantida por seus próprios e jurídicos fundamentos. 6.Agravo regimental não provido.

${ }_{17}$ Cabe ao Ministério Público, não à Defensoria Pública, atuar na defesa de crianças e adolescentes. Por isso, a Terceira Turma do Superior Tribunal de Justiça (STJ) considerou desnecessária a nomeação da Defensoria como curadora especial em ação de destituição de poder familiar.

Na hipótese de curatela de menores, o artigo 82 do Código de Processo Civil (CPC) diz que é necessária a intervenção do MP. O relator do recurso, ministro João Otávio de Noronha, acrescentou que o MP tem a função constitucional de promover os interesses do incapaz.

No caso em julgamento, o Ministério Público do Rio de Janeiro, além de figurar em um dos polos da demanda, ainda atua como fiscal da lei, o que dispensa, portanto, a nomeação de curador especial.

O MP recorreu ao STJ depois que o Tribunal de Justiça do Rio de Janeiro (TJRJ) considerou necessária a inclusão da Defensoria Pública, seja como curadora especial, seja como assistente inominado, "em razão da previsão constitucional de proteção absoluta da criança e do adolescente". 
Defensoria a atuação como curadora especial. O ministro João Otávio de Noronha fundamentou a necessidade de intervenção do Ministério Público na hipótese de curatela de menores (CPC, art. 82), pela função constitucional do Parquet de promover os interesses dos incapazes. Complementou, o ministro, ser desnecessária a atuação da Defensoria, como curadora especial, observada a atuação do Ministério Público, no referido processo, na condição de parte e de custus legis.

Respeitado o posicionamento da terceira turma do STJ, há de se destacar que o princípio da proteção integral determina uma atuação específica em prol dos interesses das crianças e dos adolescentes, não podendo ser confundida com a atuação do Ministério Público na qualidade de fiscal da lei. Se idênticas fossem as funções, o próprio STJ não teria, no julgamento do Habeas Corpus $\mathrm{n}^{\mathrm{o}}$ 250.203/SP, discordado do posicionamento do Parquet, alegando o melhor interesse da criança. ${ }^{18}$

Sem prejuízo das questões supracitadas, a cultura da violência está relacionada à questão da educação contextualizada de forma impositiva e hierárquica. A punição é socialmente aceita como modelo educativo, seja no ambiente familiar, nas escolas, nas instituições de acolhimento ou nas unidades de cumprimento de medidas socioeducativas. Acredita-se no caráter pedagógico da punição, dando legitimidade aos castigos físicos e psicológicos. Esse modelo arcaico e ultrapassado é reprodutor de violência.

\footnotetext{
Ao analisar o caso, o ministro Noronha esclareceu que a atuação da Defensoria Pública é prescindível nessa situação. "Tratando-se de ação de destituição do pátrio poder movida pelo Ministério Público, não há necessidade de nomeação de curador especial, já que a defesa do menor está sendo promovida por esse órgão, que atua na condição de parte e na função de custos legis", afirmou o magistrado.

Curatelas

Segundo Noronha, o CPC prevê que em determinadas situações o juiz nomeie curador especial para defender, no processo civil, os interesses do réu. Esse curador é chamado de curador à lide. Uma das hipóteses previstas no artigo $9^{\circ}$ do CPC é a do réu incapaz (absoluta ou relativamente) e sem representante legal. Essa curatela especial não é privativa do MP.

No entanto, sendo o caso de curatela de menor, prevista no artigo 82, inciso I, do CPC, o legislador estabeleceu que é necessária a intervenção do MP. "Nem mesmo na presença do curador à lide se exclui a intervenção do Ministério Público", observou o ministro.

O número deste processo não é divulgado em razão de segredo judicial.

18 BRASIL. STJ, Habeas Corpus no 250.203 SP. Relator. Ministro Ricardo Villas Boas Cueva. Julgado em 07 Ago.2012. Disponível em: Acesso em: 05.06.2015.
} 
Observado o acima exposto, cabe ressaltar que ainda são poucas as discussões e precários os dados acerca das violações de direitos da criança e do adolescente nas relações familiares. Tal silêncio pode ser interpretado pela falta de representatividade desses grupos e o descaso com essa parcela da população.

Não obstante a doutrina da proteção integral introduzida pelo ECA, o Estatuto ainda guarda resquícios da doutrina da situação irregular. Isso é provado nas redações dos incisos VI e VII, do artigo 88, do referido diploma legal. Observa-se a preocupação da legislação com as crianças e os adolescentes que cometeram ato infracional ou em acolhimento institucional. Em contrapartida, não há uma explícita proteção às vítimas da violência doméstica. Destacando que essa modalidade de violação de direitos atinge todas as classes sociais, sendo fundamental sua visibilidade.

Nesse contexto, um estudo realizado pelo IPEA, no ano de 2011, tendo por base de dados as informações fornecidas pelo SUS, aponta o registro de 39.281 atendimentos a indivíduos na faixa de 1 a 19 anos de idade, o equivalente a $40 \%$ do total de 98.115 casos computados pelo sistema no mesmo ano. Os maiores índices de atendimento foram às crianças menores de 1 ano de idade, com 118,9 atendimentos em 100.000 crianças. Em segundo lugar, encontravam-se os indivíduos com faixa etária de 15 a 19 anos de idade, com 84,6 atendimentos para cada 100.000 adolescentes. $^{19}$

Os dados apontaram a preponderância das violências, em sentido amplo, em face do sexo feminino. Nos anos iniciais, era pequena a diferença percentual entre os sexos. Com o aumento da idade, principalmente na adolescência e na maturidade, elevou-se a diferença das violências sofridas pelo sexo feminino. Dessa forma, do total de 39.222 atendimentos, 60,3\% eram crianças e adolescentes do sexo feminino, enquanto $39,7 \%$ eram do sexo masculino, sendo que a diferença percentual, entre os sexos feminino e masculino era, respectivamente, de 51,8\% a

\footnotetext{
${ }^{19}$ WAISELFISZ, Julio Jacobo. Mapa da Violência 2012 Crianças e Adolescentes do Brasil. p. 62
} 
48,2\%, em relação aos menores de 1 ano de idade, enquanto, elevou-se a taxa de 61,5 a $38,5 \%$, entre a faixa etária de 15 a 19 anos. $^{20}$

Os estudos apontaram que preponderam as violências, em sentido amplo, nas residências das vítimas, sendo essa incidência ainda maior contra os menores de 10 anos. Na faixa entre 10 a 19 anos de idade houve uma diminuição das violências ocorridas dentro do ambiente doméstico, mas, ainda assim, eram 2/3 dos casos. A partir dos 15 anos de idade ocorreu um aumento fora do espaço domiciliar. ${ }^{21}$

Outra questão importante foi a especificação das ocorrências de acordo com cada tipo de violência. A violência física concentrou 40,5\% dos casos de atendimento, sendo o índice de 59,6\%, na faixa entre 15 a 19 anos de idade. Em segundo lugar ficou a violência sexual com $20 \%$ dos atendimentos, especialmente na faixa entre 5 a 14 anos de idade. Em terceiro lugar estava a violência psicológica ou moral com $17 \%$ dos atendimentos. A negligência ou abandono, por sua vez, foi responsável por 16\% dos casos registrados. Essa modalidade de violência incide, principalmente, entre os menores de 1 ano a 4 anos de idade. ${ }^{22}$

Os pais foram responsáveis por 39,1\% das violências notificadas pelo SUS, no ano de 2011. Esse índice é inversamente proporcional a idade da criança. Na faixa entre 15 a 19 anos só acontece em 15,8\% dos casos. Outro dado preocupante é que entre as crianças de 5 a 14 anos há uma elevada taxa de reincidência nos atendimentos, aproximadamente $40 \%{ }^{23}$

Em relação a violência física, entre os menores de 1 ano de idade, 67, 8\% dos atendimentos foram feitos às meninas, essa proporção caiu gradualmente até os 10 anos de idade, quando as proporções ficaram praticamente iguais, com leve diferença para o sexo masculino. Esse tipo de violência demonstrou a dramática vitimização dos menores de 1 ano, que correspondia a 95,3\% dos casos. Tais dados apontaram a relação entre a

\footnotetext{
${ }^{20}$ Ibid. p. 68

${ }^{21}$ Ibid. p. 69

22 Ibid.

${ }^{23}$ WAISELFISZ, Julio Jacobo. Mapa da Violência 2012 Crianças e Adolescentes do Brasil. p. 69
} 
violência física e a vulnerabilidade. O Rio de Janeiro foi um dos líderes no número de atendimentos aos menores de 1 ano de idade. ${ }^{24}$

Não obstante, os dados revelaram que no Rio de Janeiro, dos 5.959 atendimentos 3.331 são em decorrência da violência infanto-juvenil, em sentido amplo, o que representa o percentual $55,6 \%$ do total de atendimentos. $^{25}$

Um estudo realizado pelo IPEA sobre o estupro no Brasil, tendo como base de dados os registros do SINAN, no ano de 2011, apontou que $70 \%$ das vítimas de estupro do sexo feminino são crianças e adolescentes. De acordo com os dados, 24,1\% dos agressores são os próprios pais ou padrastos, e $32 \%$ são amigos ou conhecidos da vítima. A situação é ainda mais complexa porque parcela da violência sexual contra crianças e adolescentes, principalmente, as ocorridas em ambiente doméstico, não chega aos dados oficiais. ${ }^{26}$

A violência sexual, segundo Guerra de Azevedo, é definida como:

todo o ato ou jogo sexual entre um ou mais adulto e uma criança e adolescente, tendo por finalidade estimular sexualmente esta criança/adolescente, ou utilizá-lo para obter satisfação sexual. É importante considerar que no caso de violência, a criança e adolescente são sempre vítimas e jamais culpados e que essa é uma das violências mais graves pela forma como afeta o físico e o emocional da vítima. ${ }^{27}$

As consequências da violência sexual podem ser manifestadas, tanto em aspectos físicos como psicológicos, tais como dificuldades para urinar e caminhar, dor ou coceira na genitália, DST's, edemas, masturbação constante, alternância de humor, fadiga, tendências suicidas, habito de desenhar órgão genitais, dentre outros. ${ }^{28}$

\footnotetext{
${ }^{24}$ Ibid. p. 70

${ }^{25}$ Ibid. p.

26

Disponível

em:

http://www.ipea.gov.br/portal/index.php?option=com_content\&view=article \&id=21848. Acesso em 10 mai 2015.

${ }^{27}$ Azevedo e Guerra apud AMARO, Sarita. Crianças vítmas da violência: das sombras do sofrimento à genealogia da resistência. Uma nova teoria científica. Porto Alegre: AGE/EDIPURS, 2003.p. 42.

${ }^{28}$ BRASIL. Ministério da Saúde. Violência faz mal à saúde. Brasília: Ministério da Saúde, 2004. 296 p.43.
} 
A violência doméstica, quando resulta na aplicação de medida protetiva de acolhimento institucional, assume um papel particularmente complexo na rede de significados desses indivíduos. Como bem destaca o assistente social Gilberto Lima, da Casa da Criança, em Rio Bonito, que trabalha há mais de 10 anos em instituições de acolhimento, durante a entrevista:

\begin{abstract}
A importância do advogado dentro a instituição de acolhimento. A gente trata com a adolescente vítima do abuso, mas o abusador a gente não trata(...) aí a gente encaminha para o Judiciário solicitando providências para esse abusador e a gente não tem retorno disso (...) o que se ocorre é a culpabilização da adolescente por conta de um ato que ela sofreu. $\mathrm{O}$ processo é invertido(...). Então, é muito ruim para a gente que trabalha com a adolescente porque ela é privada, como o estatuto diz, ela tem direito à convivência familiar e comunitária, ela é culpabilizada por um ato que ela sofreu e o abusador está lá dentro da casa que é um direito dele e é um direito dela também ter sua moradia e ela está institucionalizada. Então a gente quer que o direito dessa adolescente seja validado para que quando ela volte para casa não veja mais aquela figura que foi o monstro da vida dela. ${ }^{29}$
\end{abstract}

Nessa perspectiva, cabe narrar a história da menina "Joana" (nome fictício), conforme relatório psicossocial arrolado aos autos do processo que tramita em segredo de justiça. Joana foi entrevistada durante visita à Central de Triagem Taiguara. Ela demonstrava angústia em relação à medida e ao futuro. Com o propósito de resguardar a identidade da adolescente e da criança serão utilizados nomes fictícios.

(...) Joana relata que na data de 19/02/2015 sua sogra não podia tomar conta de Maria e ela solicitou que Fernando, pai de Maria, ficasse com a bebê, Fernando concordou e ela deixou a bebê na casa da sogra, sob os cuidados do genitor e foi trabalhar(...). Segundo relato, quando ela buscou Maria, percebeu que a bebê estava com ferimento na vagina. Foi ao encontro do ex-companheiro e perguntou ao mesmo o que havia ocorrido. Segundo ela, Fernando se sentiu constrangido e iniciou uma discussão com ela (...). Fernando pegou a bebê e saiu pelas ruas do bairro. A adolescente foi atrás da filha e novamente eles discutiram, porém dessa vez, Fernando agrediu fisicamente a adolescente com chutes, pontapés, puxões de cabelo e enforcamento (...) Joana relatou que buscou ajuda do tráfico local, porém não foi atendida, buscou, então, ajuda junto a UPP da área, e foi levada para a $17^{\mathrm{a}}$ DP. A adolescente relata que a delegacia estava muito cheia e não foi realizado o registro de ocorrência, ela apenas foi encaminhada para a CRCA Taiguara (...). Durante atendimento, segundo médica, a região da vagina da bebê estava com lesões, por este motivo a médica orientou que Joana buscasse a delegacia do bairro para realizar o Registro de Ocorrência. (...) Desde então, a adolescente permanece acolhida nesta Central sempre muito apreensiva e angustiada,

${ }^{29}$ Entrevista realizada com o assistente social Gilberto Lima, no dia 23 de abril de 2015. 
demonstra zelo e cuidado pela filha que demonstra bem cuidada e com desenvolvimento compatível com a faixa etária. ${ }^{30}$

Conforme observado, a institucionalização como medida protetiva, em função da violência doméstica, suscita a problemática da inversão de papéis entre vítima e autor do crime ou ato infracional, a primeira institucionalizada, privada de seu direito ao afeto, à convivência familiar e comunitária, o último, em liberdade.

Cumpre destacar a possibilidade de aplicação das medidas de urgência em relação ao agressor, tais como: afastamento do lar, domicílio ou local de convivência com a ofendida e proibição de se aproximar da mesma (Lei 11340, art. 22, II e III, a). No mesmo sentido, o Estatuto prevê o afastamento do agressor da moradia comum, verificada a hipótese acima narrada (ECA, art. 130).

A violência doméstica quando praticada contra criança e adolescente do sexo feminino enseja o debate acerca do conflito de competência. Importante destacar que a violência, em razão de gênero, determina a aplicação da Lei Maria da Penha, conforme entendimento dos tribunais superiores $^{31}$, sendo o Juizado de Violência Doméstica e Familiar contra a Mulher competente para processar e julgar os referidos crimes. Contudo, conforme disposto no artigo 13, do referido diploma legal, esse fato não afasta a aplicação subsidiária do ECA.

\footnotetext{
${ }^{30}$ Relatório social arrolado aos autos do processo 0059985-67.2015.8.19.000.

31 CONFLITO NEGATIVO DE JURISDIÇÃO - LESÕES CORPORAIS CONTRA ADOLESCENTE MULHER NO ÂMBITO DE VIOLÊNCIA DOMÉSTICA E FAMILIAR APLICABILIDADE DA LEI MARIA DA PENHA - CONDIÇÃO QUE SE SOBREPÕE AO SIMPLES FATO DE SER CRIANÇA PARA FINS DE FIXAÇÃO DE COMPETÊNCIA CARÁTER DE PROTEÇÃO CONSTITUCIONAL NÃO SÓ DAS CRIANÇAS E ADOLESCENTES, MAS TAMBÉM DA MULHER - LEI MARIA DA PENHA POSSUI UM CARÁTER MAIS ENÉRGICO DE PROTEÇÃO TOTAL - OBJETIVO PROGRAMÁTICO CONSTITUCIONAL QUE MAIS SE ALCANÇA NESTA LEI DO QUE PELO ECA DECLARAÇÃO DE COMPETÊNCIA DO JUIZADO DE VIOLÊNCIA DOMÉSTICA E FAMILIAR CONTRA A MULHER. Não se visualiza um conflito tamanho que determine que o Juizado de Proteção à Criança e ao adolescente seja preponderante. Isso porque a condição da mulher ainda adolescente tem, na Lei "Maria da Penha", um diferencial maior, cujas sanções e proteção mostram que o objetivo axiológico da norma encontra um amparo de ponderação, seja porque a própria Carta Magna observa sobre a proteção, também, da família, além, claro, das crianças e adolescentes, seja porque a Lei n. ${ }^{\circ} 11.340 / 2006$ encontrou um comando de sanção mais severo em nome daquela proteção.
} 
Nesse sentido, merece destaque a iniciativa da juíza Adriana Mello, com a criação do Projeto Violeta, responsável por maior celeridade na proteção das mulheres vítimas de violência doméstica. Tal prática consiste no encaminhamento imediato da mulher ao I Juizado da Violência Doméstica e Familiar da Capital do Rio de Janeiro, logo após o registro de ocorrência da violência, para que o juiz aprecie, na mesma hora o pedido, sem prejuízo da participação da equipe técnica. Chama-se Violeta, porque os processos que recebem essa tarja são apreciados e tem as medidas cabíveis determinas, em questão de horas. ${ }^{32}$

Não obstante, no dia 17 de junho de 2015, foi inaugurado no Rio de Janeiro o primeiro Centro de Atendimento ao Adolescente e à Criança (Caac) do Estado, com a finalidade de prestar serviço integrado e exclusivo às vítimas de violência sexual. O Caac funciona no hospital Municipal Souza Aguiar, localizado no Centro do Rio de Janeiro. O mesmo é equipado com salas especiais para a gravação de depoimentos e de realização de corpo de delito, assim como, cartório para o registro de ocorrência. Atuarão na emergência pediátrica do hospital dois policiais da DCAV e um perito do IML. ${ }^{33}$

\subsection{Instituições de Acolhimento: Conceitos e Preconceitos sobre a Institucionalização de Crianças e Adolescentes}

No Brasil, a política de assistência social é estruturada nos moldes de um Sistema Único de Assistência Social (SUAS) tendo dois segmentos de atuação: a básica e a especial. A primeira atua na prevenção de violações de direitos, seu equipamento de referência é o CRAS (Centro de Referência de Assistência Social). A segunda, por sua vez, atua nas situações em que ocorrem violações de direitos. Sua operação é realizada através dos CREAS - Centro de Referência Especializado de Assistência Social - e de

\footnotetext{
32 Disponível em: http://www.premioinnovare.com.br/praticas/projeto-violeta20140527232412433005 . Acesso em 20 mai 2015.

33 http://institutoabihpec.org.br/pedofilia/rio-abre-primeiro-centro-exclusivo-para-menoresvitimas-de-violencia sexual/?utm_campaign=shareaholic\&utm_medium=facebook\&utm_source=socialnetwork. Acesso em 30 de junho de 2015.
} 
programas e serviços especializados. No Rio de Janeiro existem 44 CRAS e 14 CREAS. $^{34}$

O CREAS, conforme Resolução CNAS n 109 de novembro de 2009, tem o Serviço Especializado de Abordagem Social e os Serviços de Acolhimento Institucional. O Serviço de Abordagem Social tem por objetivo defender direitos, prestar informações e orientações e proceder encaminhamentos aos serviços de proteção e aos serviços das políticas setoriais. A Abordagem Social é um serviço de proteção social que prevê o estabelecimento de relações de confiança e acolhida, realizada por equipe técnica composta por pedagogos, psicólogos, assistentes sociais. ${ }^{35}$

O acolhimento institucional, conforme prevê o artigo 101, VII, da Lei 8069/90 constitui medida de proteção, excepcional, sendo juridicamente inadmissível que seja violadora de direitos, uma vez que as crianças afastadas do convívio familiar já sofrem a privação dos direitos ao afeto, à convivência familiar e comunitária, consagrados na Constituição Federal. Destaca-se que a medida é excepcional, pois a Constituição ao consagrar a doutrina da proteção integral, assegurou o direito à convivência familiar como um direito fundamental ( $\mathrm{CF}$, art. 227), sendo inviável a manutenção na família natural ou extensa, deve ser promovida a integração em família substituta (ECA, art. 100, caput). O acolhimento institucional ou familiar deverá ocorrer no local mais próximo à residência dos pais ou responsáveis $\left(\mathrm{ECA}\right.$, art. $\left.101 \S 7^{\circ}\right)$

Verificada a necessidade de afastamento da criança ou do adolescente da convivência familiar, ainda que transitoriamente, o Conselho Tutelar deverá acionar o Ministério Público para a instauração do procedimento judicial (ECA, art. 136, XI). Não obstante, isso não significa que o Conselho Tutelar deva ficar inerte. Uma vez verificada essas hipóteses, imediatamente a criança ou o adolescente deverá ser encaminhado para local seguro (ECA, art. 236, parágrafo único).

\footnotetext{
${ }^{34}$ Política Nacional de Assistência Social PNAS/ 2004, Brasília, Novembro 2005 e Relatório de visitas aos “ABRIGOS ESPECIALIZADOS” para crianças e adolescentes, junho de 2012,p. 11.

35 Resolução CNAS n 109 de novembro de 2009.
} 
$\mathrm{O}$ acolhimento institucional ocorre nas hipóteses em que as crianças ou os adolescentes apresentam um quadro de fragilidade física e/ou emocional, ou seja, encontram-se desprotegidos, em situação de risco ou vulnerabilidade que impossibilitem a permanência na família natural. Ocorrida qualquer dessas hipóteses, deverá ser privilegiada a convivência familiar, seja através da família extensa, colocação em acolhimento familiar ou, ainda, família substituta, respeitado o devido processo legal.

Nesse sentido, a psicologia, através de estudos, aponta consequências negativas resultantes da política de acolhimento institucional. Conforme estudo realizado por Joana Bick, do Boston Children's Hospital (EUA):

\begin{abstract}
"nos últimos cinquenta anos, o modelo de acolhimento institucional tipo abrigo vem sendo gradativamente abandonado na Europa Ocidental, movimento impulsionado, de um lado, pelo maior custo de manutenção de acolhidos em instituições, de outro por estudos apontando os males da institucionalização de crianças e adolescentes retirados do convívio familiar. Estudos realizados nas décadas de 50 e 60 na Inglaterra e na então recente Checoslováquia, apontaram a dificuldade de crianças institucionalizadas em criar vínculos emocionais com seus cuidadores, o que se devia à troca de turnos de trabalho nas instituições e à disciplina regimental que não atendia às necessidades individuais das crianças. A carência de contato físico e afetivo, aliada à falta de adequado estímulo e interação, resultou em atrasos no desenvolvimento e distúrbios de comportamento tanto nas crianças inglesas quanto tchecas" 36
\end{abstract}

Essas consequências podem ser explicadas pelo fato das instituições de acolhimento serem espécies de instituições totais. As instituições totais, como denomina Goffman, criam para seus participantes uma espécie de mundo. Todas as atividades são realizadas com o mesmo grupo, numa relação de vigilância, perde-se a individualidade em prol de um padrão coletivo de ordem.

O aspecto central das instituições totais pode ser descrito coro a ruptura das barreiras que comumente separam essas três esferas da vida. Em primeiro lugar, todos os aspectos da vida são realizados no mesmo local e sob urna única autoridade. Em segundo lugar, cada fase da atividade diária do participante é

\footnotetext{
${ }^{36}$ BICK, Johanna. The Equal Rights Review (2012) Tradução "In the 1950s and 1960s, studies in Britain and the former Czechoslovakia noted that children in institutions struggled to form healthy emotional attachments to their carers. This was due to the number of carers working shifts in the institutions, and the regimented regime that could not respond to the individual needs and demands of children. The lack of emotional and physical contact, together with a lack of regular stimulation and interaction, resulted in specific developmental delays and challenging behaviours common to both British and Czechoslovakian children".
} 
realizada na companhia imediata de um grupo relativamente grande de outras pessoas, todas elas tratadas da mesma forma e abrigadas a fazer as mesmas coisas em conjunto. Ero terceiro lugar, todas as atividades diárias são rigorosas, mente estabelecidas em horários, pois urna atividade leva, em tempo predeterminado, a seguinte, e toda a sequência de atividades é imposta de cima, por um sistema de regras formais explícitas e um grupo de funcionários. Finalmente, as várias atividades obrigatórias são reunidas num plano racional único, supostamente planejado para atender aos objetivos oficiais da instituição. ${ }^{37}$

Dessa forma, a instituição de acolhimento cria para a criança e o adolescente uma espécie de universo com características e rede de significados próprios limitados àquele espaço. Os indivíduos estão sempre sob vigilância, não tem participação no processo de escolhas, as regras são impostas de forma a criarem uma realidade própria. Nesse sentido, cabe destacar as palavras de Focault :

A minúcia dos regulamentos, o olhar esmiuçante das inspeções, o controle das mínimas parcelas da vida e do corpo darão, em breve, no quadro da escola, do quartel, do hospital ou da oficina, um conteúdo laicizado, uma racionalidade econômica ou técnica a esse cálculo místico do ínfimo e do infinito. ${ }^{38}$

Não obstante, o dirigente da entidade que desenvolve programa de acolhimento institucional é equiparado a guardião e detentor dos deveres de guarda e cuidado, não de representação legal (artigo 92, § $1^{\circ}$ c/c 142 da Lei 8.060/90).

Tratando de instituições é importante trabalhar o papel da escola na formação do indivíduo em acolhimento institucional. Essa exerce um importante papel na rede de significados da criança e do adolescente institucionalizados, pois constrói uma nova rede de convivência. Essa troca de experiências, com diferentes sujeitos e histórias, contribui para a ampliação do universo desses indivíduos.

Dessa forma, o ambiente escolar pode significar espaço de inclusão ou exclusão. Os pedagogos apontam para o problema da padronização educacional. A escola não está preparada para a heterogeneidade de alunos,

\footnotetext{
${ }^{37}$ GOFFMAN, E. (1987). Manicômios, prisões e conventos. $2^{\mathrm{a}}$ ed. São Paulo: Perspectiva. p. 17 e 18.

${ }^{38}$ FOUCAULT, Michel. Vigiar e Punir: O nascimento da Prisão.37.Ed. Rio de Janeiro: Editora Vozes,2009.p. 121.
} 
uma vez que idealiza um perfil e responsabiliza o indivíduo que não corresponde a tal expectativa. ${ }^{39}$

Não obstante, a criança e o adolescente institucionalizados, muitas vezes, sofrem o estigma de "menor infrator", conforme relatou o psicólogo Alexandro Nascimento Vieira, da Casa da Criança. Visto como fracassado, limitado e incompetente, cria-se uma dificuldade de interação entre a criança institucionalmente acolhida e a escola.

Tal perspectiva deve ser alterada por uma pedagogia participativa, cujos indivíduos encontrem no ambiente escolar um espaço de crítica e mudança da sua própria realidade e, consequentemente, a do mundo. Existe, no atual modelo, uma limitação à criatividade, ao pensamento e ao protagonismo. ${ }^{41}$ Chamar o aluno por número, denominá-lo de fracassado por uma nota é, no mínimo, contraditório com os objetivos de uma pedagogia progressista, conforme leciona Milton Santos:

\begin{abstract}
"A educação corrente e formal, simplificadora das realidades do mundo, subordinada à lógica dos negócios, subserviente às noções de sucesso, ensina um humanismo sem coragem, mais destinado a ser um corpo de doutrina independente do mundo real que nos cerca, condenado a ser um humanismo silente, ultrapassado, incapaz de atingir uma visão sintética das coisas que existem, quando o humanismo verdadeiro tem de ser constantemente renovado, para não ser conformista e poder dar resposta às aspirações efetivas da sociedade, necessárias ao trabalho permanente de recomposição do homem livre, para que ele se ponha à altura do seu tempo histórico."42
\end{abstract}

Quanto aos seus aspectos estruturais, a instituição de acolhimento em nada lembra a cultura familiar e tal traço é característico desde a questão arquitetônica à forma de imposição da disciplina. Em duas das visitas realizadas, a da Central Carioca e a do Educandário Professor Almir Ribeiro Madeira, mesmo sem saber exatamente a localização, foi possível reconhecê-las. Muros altos, predominância das cores azul e branco, características muito próximas às unidades de cumprimento de medida

\footnotetext{
${ }^{39}$ ALMEIDA, Ivy Gonçalves de; Rossetti-ferreira, Maria Clotilde; Serrano, Solange Aparecida. $O$ Acolhimento Institucional na Perspectiva da Criança. Editora: HUCITEC pp. 175-198.

${ }^{40}$ Essa questão foi levantada pela equipe técnica da instituição de acolhimentp Casa da Criança. O termo correto para adolescentes que cometem ato infracional é adolescente em conflito com a lei. No entanto, o termo menor infrator é utilizado exatamente com o intuito pejorativo.

${ }^{41}$ Alves R. Conversas com quem gosta de ensinar. São Paulo:Ars Poética;1995.

${ }^{42}$ SANTOS, Milton. Espaço e método. São Paulo: Nobel, 1985, p.42.
} 
socioeducativa. Nesse sentido, cumpre destacar os ensinamentos de Milton Santos a respeito dos objetos no espaço geográfico e suas adequações, definindo como forma, função, estrutura e processo, quando analisados em conjunto, ensejam a discussão dos fenômenos espaciais em sua totalidade.

(...) forma, função, estrutura e processo são quatro termos disjuntivos, mas associados, a empregar segundo um contexto do mundo de todo dia. Tomados individualmente, representam apenas realidades parciais, limitadas, do mundo. Considerando em conjunto, porém, e relacionados entre si, eles constroem uma base teórica e metodológica a partir da qual podemos discutir os fenômenos espaciais em totalidade. ${ }^{43}$

$\mathrm{Na}$ instituição Casa da Criança, por exemplo, há uma preocupação nesse sentido. A arquitetura é similar às das casas locais, sendo impossível sua imediata associação a qualquer finalidade (foto 1 do anexo 4). A equipe técnica também demonstrou preocupação quanto ao carro utilizado não gerar identificação institucional. Disseram ainda que, durante realização de eventos externos, evitam qualquer forma de exposição das crianças e dos adolescentes. Embora possa parecer uma questão superficial, cada escolha no campo da infância assume um relevante significado. Comparando os modelos protetivo e socioeducativo é possível perceber as semelhanças.

Na unidade de cumprimento de medida socioeducativa Educandário Santo Expedito, no Rio de Janeiro, é possível observar os traços singelos que unem ambos os sistemas. A unidade de internação tem ação civil pública, movida pelo Ministério Público, com o objetivo de desativá-la ${ }^{44}$. A Defensoria também ingressou com uma ação civil pública pedindo a interdição da unidade. Segundo a doutora Eufrásia, atual coordenadora da Cdedica, a unidade que fica no sistema penitenciário, em Bangu, não atende aos parâmetros da lei. ${ }^{45}$ Condições insalubres (fotos 2-5 do anexo 4), superlotação, dentre outros, são alguns dos problemas apontados pela

\footnotetext{
${ }^{43}$ SANTOS, Milton. Espaço e método. São Paulo: Nobel, 1985, p.71

${ }^{44}$ http://odia.ig.com.br/noticia/rio-de-janeiro/2014-06-06/degase-vai-fechar-unidade-em-bangupor-denuncias-de-maus-tratos.html.

45 http://odia.ig.com.br/noticia/rio-de-janeiro/2015-03-24/rebeliao-e-tragedia-anunciada-dizpresidente-do-sind-degase.html.
} 
unidade que, por suas rebeliões, sempre é destaque na mídia. ${ }^{46}$ Em visita à Central de Triagem Carioca, foi possível perceber os mesmos problemas apresentados na unidade de internação. A diretora informou, ainda, que muitos adolescentes chegam algemados do DEGASE, após circularem durante horas na van, sendo flagrante a ilegalidade da conduta. ${ }^{47}$ Durante a realização da visita, junto com a CDEDICA, não foi possível tirar fotos da instituição, pois um representante do município foi comunicado sobre a presença da Defensoria e impediu a realização do feito, alegando ser competência do Ministério Público.

Sem prejuízo dos pontos acima sustentados, o Estatuto da Criança e do Adolescente é considerado uma das legislações mais avançadas do mundo no que se refere à proteção da infância e da adolescência. Entretanto, seus dispositivos ainda não se mostram eficazes.

Nesse sentido, a lei prevê que toda criança em programa de acolhimento institucional deverá ter sua condição reavaliada, no máximo a cada seis meses (ECA art. 19, $\S 1^{\circ}$ ), sendo o tempo de permanência institucional limitado a, no máximo, dois anos (ECA art. $19, \S 2^{\circ}$ ). Conduto, tal objetivo de limitação temporal não é alcançado em razão de entraves sociais e jurídicos.

Nesse contexto, existe uma realidade de crianças inadotáveis, por conta das restrições impostas pelos pretendentes a adoção e pelo Judiciário e, as invisíveis, que nunca estiveram cadastradas, conforme casos que

\footnotetext{
${ }^{46}$ A defensora pública Eufrásia Maria Souza das Virgens, que atua na Coordenadoria de Defesa dos Direitos da Criança e Adolescente, no Rio, disse que, em 2005, o órgão entrou com uma Ação Civil Pública pedindo que o estado interditasse o Santo Expedito, por ser inapropriado para abrigar menores em conflito com a lei.

"Já teve sentença, mas o estado recorreu. Há um agravo com recurso extraordinário que está sendo apreciado pelo ministro Luiz Fux, do STF. Essa unidade fica no sistema penitenciário, em Bangu. Não atende os parâmetros da lei”, explicou ela.

A Defensoria vai reiterar junto à Vara da Infância e Juventude que os adolescentes do Santo Expedito que não tenham cometido ato infracional com violência sejam transferidos para programa de meio aberto. O objetivo é diminuir pelo menos o quadro de superlotação. Com isso, eles seriam colocados em liberdade assistida. Disponível no site http://odia.ig.com.br/

47 Trabalho de campo realizado em novembro de 2013. Não foi proibido tirar fotos, segundo um representante do município precisaria de autorização do Ministério Público.
} 
ensejaram ações de indenização ${ }^{48}$. Outras estão em instituições de acolhimento, mas não estão disponíveis para a adoção. Independente dos motivos, que são diversos, o fato relevante para o presente trabalho é que muitas dessas crianças e adolescentes passarão um período, curto ou longo, nessas instituições.

Tendo por pressuposto essa realidade é preciso trabalhar para que a passagem pelo sistema institucional não seja traumática. O primeiro passo para esse objetivo é desmistificar a ideia de que toda criança que passou pelo acolhimento institucional, necessariamente, terá consequências negativas no futuro. Os resultados são provenientes de atos. Se as instituições de acolhimento produzem consequências negativas, tal fato decorre em razão de seu mau funcionamento.

Dessa forma, uma série de medidas devem ser tomadas, desde questões de espaço estrutural a outras relacionadas ao afeto. Torna-se fundamental evitar a separação de grupos de irmãos. Sem a presença de um adulto, provavelmente os vínculos afetivos serão transmitidos aos mais próximos. Isso se deve também ao fato de que, alguns desses grupos de irmãos, vivenciaram situações complexas juntos, antes mesmo do acolhimento, sem a presença dos pais, visto que a negligência é a maior causa de institucionalização. ${ }^{49}$

Todavia, muitas vezes, é suprimida em razão de exigências técnicas, como divisão das instituições por sexo ou idade. Outro impedimento é, conforme relatado pelo psicólogo Alexandro Nascimento Vieira, da Casa da Criança, a preocupação com a questão sexual na divisão de quartos. Dessa forma, irmãos ficam separados, ainda que na mesma instituição, quando há uma diferença de idade ou sexo.

Questão também relevante a ser trabalhada é a preservação do direito à identidade dentro do espaço institucional. O indivíduo deve ter o direito,

\footnotetext{
48 Por erro da Justiça crianças crescem fora da fila de adoção, Disponível em http://oabrj.jusbrasil.com.br. Acesso em 15 mai 2015.

ALMEIDA, Ivy Gonçalves de; ROSSETTI-FERREIRA, Maria Clotilde; SERRANO, Solange Aparecida. O acolhimento Institucional na Perspectiva da Criança, p. 125.
} 
dentro do universo de possibilidades, a fazer escolhas quanto às roupas, corte de cabelo, maquiagem e demais matérias cotidianas que interferem na construção da sua imagem. Embora possa parecer uma questão periférica, num espaço de padronização, como a instituição de acolhimento, é necessário trabalhar a representatividade no meio social. Vale lembrar a forma brilhante como Machado de Assis trabalhou essa questão no conto $\mathrm{O}$ Espelho. O narrador aborda o fato de cada indivíduo ter duas almas, a externa e a interna. Trabalha, a narrativa, com o fato de questões exteriores estarem tão intrínsecas, ao indivíduo, de forma que representam sua própria existência. Nesse passo, ele cita o exemplo do personagem Shylock, cuja alma exterior eram seus ducados e perdê-los significou a morte. De mais a mais, a história principal era do Jacobina, que todos os dias, ao longo de seis meses, vestia-se de alferes e se olhava no espelho. Ao vestir-se de alferes e observar sua imagem, transforma-se, de indivíduo apático, em pessoa forte, capaz de vencer seis meses de solidão sem os sentir. ${ }^{50}$

Consoante o exposto, a criança e o adolescente em situação de acolhimento institucional devem ser ouvidos como sujeitos de direitos e autores das suas próprias histórias. Não obstante a mudança de paradigma, quase sempre esses indivíduos são tratados como objetos de direito a sofrerem intervenção. Os envolvidos na rede de significados desses sujeitos devem atentar às suas demandas, pois a construção e a formação da individualidade se tornam ainda mais complexas num espaço de discurso de ordem em massa.

Os profissionais assumem, portanto, papel fundamental na rede de significados desses sujeitos em formação. A atuação desse grupo será um dos principais aspectos para o desenvolvimento, superação de traumas e construção de novos objetivos. Portanto, educadores sociais despreparados representam a violação de uma etapa importante no desenvolvimento de crianças e adolescentes. Nesse sentido, existe o Projeto de Lei 5346/2009,

\footnotetext{
${ }^{50}$ ASSIS, Machado de. Obra Completa. Rio de Janeiro: Nova Aguilar 1994. v. II. Disponível em: http://www.bibvirt.futuro.usp.br>. Acesso em 10 mai 2015.
} 
aguardando Parecer do Relator na Comissão de Constituição e Justiça e de Cidadania, que dispõe sobre a criação da profissão de educador e educadora social e dá outras providências. Segundo a proposta, será de responsabilidade do Ministério da Educação a elaboração e regulamentação da Política Nacional de Formação em Educação Social, desses profissionais.

Observados os pontos acima expostos, há de se discutir a legitimidade das instituiçõos de acolhimento. Elas parecem configurar uma exceção à Constituição Federal e ao Estatuto da Criança e do Adolescente no tocante ao dever da comunidade de assegurar os direitos das crianças e dos adolescentes. Isso se apresenta na forma com a sociedade negligencia esses espaços, intensificando o processo de exclusão desses ambientes e dos indivíduos que neles habitam.

Dessa forma, é preciso uma conscientização a respeito da existência e da necessidade das instituições de acolhimento. Partindo desse pressuposto, devem ser trabalhados meios para eficácia da medida protetiva na superação de traumas e descobertas de novas possiblidades de vida. Quanto maior a participação da sociedade, a superação de preconceitos e estigmas, a ampliação das redes de significados desses indivíduos, melhores serão os resultados. No mais, a infância e a adolescência constituem um período curto, entretanto, essencial na formação do indivíduo, não podendo ficar refém do discurso de marginalização.

Não obstante, há de se enfatizar que o cuidado e a melhoria das instituições de acolhimento não excluem os investimentos na manutenção da convivência familiar, como políticas públicas voltadas para a família natural e extensa, incentivos à família acolhedora ou substituta, sequer é uma concorrência com os mesmos. Inclusive, nesse sentido, segundo a doutora Márcia Fernandes, ex-coordenadora da CDEDICA, a Defensoria está conversando com a prefeitura do Município do Rio de Janeiro para que a verba disponibilizada para a família acolhedora também possa abranger a família extensa. Contudo, é necessário um olhar crítico para um problema 
existente. Conforme acima mencionado, crianças e adolescentes passam pelo acolhimento institucional, pelos mais variados motivos e por distintos períodos de tempo. Assim, é preciso escolher entre manter esses ambientes na exclusão ou transformá-los em espaços capazes de contribuir na superação de traumas. Certamente, o princípio da proteção integral é pertinente com a segunda opção. 


\section{DO SAM ÀS INSTITUIÇÕES DE ACOLHIMENTO. BREVE COMPARAÇÃO DOS MODELOS BRASILEIROS DE INSTITUCIONALIZAÇÃO E A IMPORTÂNCIA DO MOVIMENTO DOS MENINOS E MENINAS DE RUA NA APROVAÇÃO DO ESTATUTO DA CRIANÇA E DO ADOLESCENTE}

Determinado estabelecimento do Serviço, asseveraramme, chegara a se transformar em centro aberto de lenocínio. $O$ encarregado, ele em pessoa, escolhia as mocinhas, enfeitava-as, levando-as, em seguida, à casa da senhora Maria da Conceição, onde não raro pernoitavam, servindo de pasto à luxuria de moços e velhos devassos, quando não, tarados, endinheirados. Jamais se soube ao certo do destino de muitas dessas vítimas.

(NOGUEIRA FILHO, 1956, p. 59).

O Estado, ineficiente em políticas públicas, encontra na institucionalização a solução para esconder uma massa de indesejáveis. Conforme abordado no primeiro capítulo, há hipóteses em que o acolhimento institucional se faz necessário. Contudo, essas instituições se transformaram em depósitos de crianças reforçando o modelo de exclusão social.

O presente capítulo abordará os modelos brasileiros de institucionalização, desde a promulgação do Código de Menores até os dias atuais. Serão discutidos os processos de continuidades e rupturas, assim como o perfil da criança e do adolescente institucionalizados e das instituições no decorrer dos anos.

Em 1927, entrou em vigor o Código Mello Mattos, a primeira legislação de proteção à infância e juventude. Contudo, seu conteúdo não consagrava os direitos fundamentais das crianças e dos adolescentes, sendo 
uma legislação de forte cunho discriminatório. Pelo seu conteúdo higienista tinha como público indivíduos com "patologia social". O atendimento na área da infância era baseado na tríade pobreza, delinquência e perigo. ${ }^{51}$

Em 1941, durante o Estado Novo, foi criado o Serviço de Assistência do Menor (SAM). O órgão era vinculado ao Ministério da Justiça e tinha o objetivo de atender à infância desvalida, através da correção e da repressão. Não havia autonomia administrativa ou financeira. ${ }^{52}$

O SAM tinha o propósito de se expandir pelo país na assistência aos desvalidos. Entretanto, desviou-se de suas finalidades e ficou famoso pelas péssimas condições de funcionamento responsáveis, inclusive, pelo falecimento de menores. Outra realidade institucional era o esquema de favorecimentos para empregos e corrupção. ${ }^{53}$

A instituição adotou o modelo de educação através do medo. Não havia qualquer respeito a identidade individual dos sujeitos internados, sendo o uso de uniforme obrigatório e as rotinas das atividades inflexíveis. $^{54}$

A respeito do caos existente na instituição, Paulo Nogueira, exdiretor, denunciou o sistema de corrupção e as péssimas condições das instalações no seu livro "SAM, Sangue, Corrupção e Vergonha”, in verbis:

\footnotetext{
Espantou-me a promiscuidade em que viviam aqueles seres de todos os tamanhos, de todas as idades e procedência, vivendo numa ociosidade deprimente. Comiam e dormiam; uns entregavam-se à pederastia e outros fumavam maconha; os que podiam incorporavam-se a "gang" para as excursões externas de rapina ou para a promoção de rebeliões internas. Nem livro, nem uma aula, nem um esporte. O projetor cinematográfico estava quebrado; não havia bola, nem peteca, nem ginástica e muito menos rádio ou vitrola. Para distração, os menores ouviam, de quando em quando, gritos dos enclausurados e viam, diante de si, permanentemente, os muros alvos e altos, que, encimados por uma rede de arame farpado, circulavam a casa e o pátio. ${ }^{55}$
}

\footnotetext{
${ }^{51}$ Curso sobre a Infância Introdução ao Direito da Infância e Juventude - Turma 12, realizado de 19 de janeiro a 25 de fevereiro de 2015 .

${ }^{52}$ Curso sobre a Infância Introdução ao Direito da Infância e Juventude - Turma 12, realizado de 19 de janeiro a 25 de fevereiro de 2015.

${ }^{53}$ RIZZINI. Irene. Op.cit, p. 33.

${ }^{54}$ Ibid. p. 34.

${ }^{55}$ NOGUEIRA FILHO,Paulo. Sangue, corrupção e vergonha S.A.M.: sangue da mocidade, lama da corrupção e vergonha da incúria recaem sobre a sociedade brasileira, enquanto perdura a tragédia dos menores abandonados São Paulo: Revista dos Tribunais, 1956. p. 37.
} 
O diretor relatou, ainda, a exploração sexual de meninas. Demonstrando a problemática da questão de gênero dentro das instituições. Segundo o ex-diretor, não se soube o destino de muitas dessas vítimas. ${ }^{56}$

As instituições eram divididas de acordo com dois perfis, o das crianças abandonadas e o dos adolescentes delinquentes. As crianças abandonadas eram encaminhadas para escolas agrícolas ou de aprendizagem. Os “infratores” eram internados em reformatórios e casas de correção. $^{57}$

A mídia exerceu um importante papel na construção negativa da imagem do adolescente que passava pelo SAM. Apontava, nas manchetes, tanto as péssimas condições das instalações, como estigmatizava o adolescente acolhido de "menor infrator".

Após inúmeras críticas, papel ativo da imprensa e denúncias, formou-se na sociedade a opinião de que o SAM não correspondia aos propósitos para os quais havia sido criado. A instituição era vista como fábrica de criminosos.

Em 1964, com o golpe militar, o SAM foi substituído pela FUNABEM. A proposta do novo modelo de institucionalização era se opor ao paradigma de depósito de menores. Ao contrário da instituição anterior, a FUNABEM tinha autonomia financeira e administrativa.

A Política Nacional de Bem-Estar do Menor (PNBEM) foi implementada pela lei 4.513/1964, no governo de Castelo Branco. No Rio de Janeiro, a lei estadual 1.334/1967, autorizou o Poder Executivo a criar a Fundação do Bem-Estar do Menor- FEBEM. A FEBEM era vinculada à Secretaria de Estado e Serviço Social, seu objetivo era atender o menor entre 0 a 18 anos de idade do Estado da Guanabara. No mesmo período foi criada a Fundação Fluminense do Bem-Estar do Menor- FLUBEM, sendo responsável pela área do antigo Estado do Rio de Janeiro. ${ }^{58}$

\footnotetext{
${ }^{56}$ Ibid. p. 55.

${ }^{57}$ Curso sobre a Infância Introdução ao Direito da Infância e Juventude - Turma 12, realizado de 19 de janeiro a 25 de fevereiro de 2015.

${ }^{58}$ Disponível em: http://www.fia.rj.gov.br/historia.htm. Acesso em 10 mai 2015.
} 
Como o próprio regime vigente na época, a FEBEM tinha sua política pública pautada na repressão e na restrição dos direitos fundamentais. Implementada num cenário de segurança nacional, foi responsável por afastar da sociedade qualquer entrave a esse paradigma idealizado. Nesse sentido, a instituição nivelou todas as crianças e jovens que precisavam de atendimento, sem separar as crianças em situação de abandono daquelas que cometiam atos infracionais. ${ }^{59}$

Buscando não repetir os erros do antigo modelo, as escolas da Ilha do Governador e de Quintino foram recuperadas. Com a justificativa de estudar novos modelos a serem implementados através de uma rede nacional de entidades públicas-fundações ou secretarias pertinentes e entidades privadas, foram mantidos os atendimentos, pelo órgão normativo, nos treze estabelecimentos oficiais do Rio de Janeiro. ${ }^{60}$

A proposta da FUNABEM era acabar com a fama de excessiva internação do modelo anterior e buscar a reintegração da criança e do adolescente à convivência familiar e comunitária. Isso seria realizado através do estudo sobre o menor e a assistência social a família. A internação seria medida excepcional, apenas em última hipótese. Defendia a busca pela prevenção da delinquência, com a participação da própria juventude e descentralização das atividades. ${ }^{61}$

Entretanto, os objetivos não foram alcançados. Em 1969, o jornal Diário de Brasília noticiou a retirada de crianças das ruas e de suas famílias pobres como política de segurança pública. Nesse sentido, o juiz de menores, o doutor Alírio Cavalleri, ao falar sobre as expectativas para o ano de 1970 e realizações dos anos 60, expôs como positiva a retirada de 10 mil menores da rua. Revelou como problemático o fato do povo carioca ter que conviver com menores mendigando, vendendo drogas, limpando para-brisas e cometendo desordens. Dentre as expectativas para a década de 70 , o juiz

\footnotetext{
${ }^{59}$ RIZZINI, Irene; RIZZINI, Irma. A institucionalização de crianças no Brasil: percurso histórico e desafios do presente. Rio de Janeiro : Ed. PUC-Rio; São Paulo : Loyola, 2004.p. 34.

${ }^{60}$ RIZZINI, Irene; RIZZINI, Irma. A institucionalização de crianças no Brasil: percurso histórico e desafios do presente. Rio de Janeiro : Ed. PUC-Rio; São Paulo : Loyola, 2004.pp 36-39.

${ }^{61}$ RIZZINI, Irene; RIZZINI, Irma. Op.cit. pp 36-39.
} 
enfatizou a esperança na revogação do artigo 33 do Código Penal, a ampliação da assistência social para diversos atendimentos fora da internação, a intensificação do trabalho de reeducação dos menores infratores e a reestruturação do Judiciário com a criação de novos cargos. ${ }^{62}$

A imprensa alarmou a sociedade sobre os problemas dos adolescentes institucionalizados na FEBEM. Um jornal de grande circulação, o Diário de Brasília, uma semana após o dia das crianças, em 1974, trouxe como manchete "menores sem solução?". A matéria criticava a falta de planos reais na solução da infância e da adolescência marginalizadas. Segundo o conteúdo, as críticas ao SAM ficaram exclusivamente no campo teórico, pois as questões levantadas pela nova proposta careciam de efetividade. Nesse sentido, cabe destacar a entrevista dada pelo ministro Justiça da época, Alfredo Buzaid, acerca do problema levantado:

\begin{abstract}
O aumento do número de menores marginalizados pode afetar o desenvolvimento brasileiro e a segurança nacional, porque os menores comprometidos, física, moral ou intelectualmente, embaraçam o desenvolvimento e se tornam presas fáceis de agentes internacionais, que atuam no plano da destruição dos valores tradicionais da família brasileira. ${ }^{63}$
\end{abstract}

Em 1975, em razão de denúncias de maus tratos e corrupção, foi instalada uma Comissão Parlamentar de Inquérito. A política continuou sendo de recolhimento em massa, assim como a do SAM. Sendo dessa vez, importante aos ideais da ditadura que crianças não estivessem nas ruas. ${ }^{64}$

No mesmo ano, com a fusão dos estados da Guanabara e do Rio de Janeiro, tornando-se o Estado do Rio de Janeiro, através do Decreto lei 42/1975, a FEBEM assumiu a nomenclatura de Fundação Estadual de Educação do Menor- FEEM e da FLUBEM. A FEEM era vinculada à Secretaria de Estado e de Educação. Passou a ser responsável também pelo atendimento executado pela FLUBEM. ${ }^{65}$

\footnotetext{
${ }^{62}$ Diário de Brasília, 1969. P. 14, 1a seção. Material disponível no acervo da Biblioteca Nacional.

${ }^{63}$ Correio da Manhã, 19 de outro de 1974. Material disponível no acervo da Biblioteca Nacional.

${ }^{64}$ RIZZINI, Irene; RIZZINI, Irma. Op.cit. p 41.

${ }^{65}$ Disponível em: www.fia.rj.gov.br. Acesso em 20 mai 2015.
} 
Em 1979, foi promulgado o Código de Menores. Em relação ao Código Melo de Matos a mudança foi singela, apenas contemplando a Doutrina Jurídica do Menor em Situação Irregular, descrevendo quando e em quais hipóteses as crianças estariam em situação irregular e necessitariam da intervenção do Estado. O grande avanço foi na adoção, antes apenas disciplinada pelo Código Civil. ${ }^{66}$

Em 1987, a FEEM passou a ser vinculada à Secretaria de Estado de Trabalho e Ação Social. Seus princípios e diretrizes foram estabelecidas na Política Nacional do Bem-Estar do Menor, formulada e implantada pela FUNABEM. $^{67}$

Em 1982, no embalo de vários movimentos sociais, surgiu o Movimento de Meninos e Meninas de Rua. Em 1985, esse movimento alcançou o status de entidade civil organizada. O objetivo do movimento era a capacitação das crianças e dos adolescentes no exercício da reivindicação dos próprios direitos. A atuação foi em conjunto com diversos segmentos envolvidos diretamente nas discussões sobre a infância e a adolescência marginalizadas. O propósito era superar a política implementada pela FUNABEM, responsável por inúmeras violações de direitos, dentre as quais, as péssimas condições das instalações e os casos de tortura. O movimento tinha uma identidade própria, sem vínculo partidário ou institucional. $^{68}$

Esse movimento se destacou, principalmente, pela participação das crianças como protagonistas das suas histórias e capazes de reivindicar seus direitos. Tal fato representou a efetividade da criança como sujeito direito, aspecto relevante na implementação da doutrina da proteção integral na Constituição Federal de 1988 e no Estatuto da Criança e do Adolescente.

\footnotetext{
${ }^{66}$ O conteúdo deste tópico foi retirado do artigo "O sistema de garantia dos direitos de crianças e adolescentes" de Graça Gadelha, Eliane Bispo e Fernando Luz. O texto possui adaptações realizadas por Daniela de Macedo B.R.T. de Sousa, para a adequação do material à temática proposta. In Curso sobre a Infância Introdução ao Direito da Infância e Juventude - Turma 12, realizado de 19 de janeiro a 25 de fevereiro de 2015.

${ }^{67}$ Disponível em: www.fia.rj.gov.br. Acesso em 20 mai 2015.

${ }^{68}$ VOLPI, M. Sem Liberdade, Sem Direitos: a privação da liberdade na percepção do adolescente. SP: Cortez, 2001, pág. 30.
} 
A atuação principal do movimento foi na conscientização da parcela vulnerável da população acerca dos seus direitos, da importância da organização conjunta na luta pela implementação dos mesmos e na discussão sobre as políticas públicas disponíveis e necessárias. Com esse objetivo, os educadores romperam com o modelo tradicional atuando nos moldes da educação popular, conforme os princípios progressistas da pedagogia do oprimido de Paulo Freire. Em 1980, surgiu o Projeto Alternativas de Atendimento aos Meninos e Meninas de Rua, tendo por finalidade o intercâmbio de experiências e ideias no atendimento a esse grupo. ${ }^{69}$

O movimento participou ativamente da constituinte de 1988. O grupo enfatizou a importância dos direitos das crianças e dos adolescentes estarem expressos na lei, pois apenas assim poderiam exigi-los. Com esse propósito organizaram duas campanhas, a primeira intitulada "Criança e Constituinte", tendo por público alvo crianças até 6 anos de idade. A segunda denominada "Criança e Prioridade Nacional”, tendo por público alvo adolescentes. Essas campanhas foram fundamentais para a aprovação dos artigos 227 e 228 da Constituição Federal. ${ }^{70}$

Após a aprovação dos direitos fundamentais da infância e da adolescência no texto constitucional era necessária uma legislação que os regulamentasse. Nesse sentido, em 1989, foi apresentado, na Câmara dos Deputados, projeto de lei denominado "Normas gerais de Proteção à Infância e à Juventude", com apoio de juristas consultores do Fundo das Nações Unidas para a Infância e de outros movimentos engajados na causa dos direitos de crianças e adolescentes. ${ }^{71}$

Após seis versões, o projeto foi apresentado ao Senado Federal. Em setembro 1989, houve o II Encontro Nacional de Meninos e Meninas de Rua, onde ocorreu votação simbólica da lei pelas crianças que participavam

\footnotetext{
${ }^{69}$ VOLPI, M. Sem Liberdade, Sem Direitos: a privação da liberdade na percepção do adolescente. SP: Cortez, 2001, pág. 30.

${ }^{70} \mathrm{Ibid}$.

${ }^{71}$ Ibid.
} 
do evento. Em 29/06/1990 foi sancionado pelo presidente da república e, em 14/10/1990, o Estatuto da Criança e do Adolescente entrou em vigor. ${ }^{72}$

Com a nova ordem constitucional e a implementação dos direitos, garantidos nos artigos 227 e 228 da Constituição Federal e expressos na Convenção Internacional dos Direitos da Criança e no Estatuto da Criança e do Adolescente, abandonou-se a perspectiva do Bem-Estar do Menor e foi implementada a Doutrina da Proteção Integral. Esse novo paradigma é pautado na responsabilidade pelas violações praticadas em face de crianças e adolescentes. Essa responsabilidade tem por base $\mathrm{o}$ direito à sobrevivência, ao desenvolvimento e à integridade. ${ }^{73}$

O modelo de institucionalização vigente na época não condizia com as novas determinações legislativas. Nesse sentido, não cabia mais o encaminhamento de crianças em situação de vulnerabilidade para as mesmas instituições de adolescentes que cometeram atos infracionais. Dessa forma, foram separadas as instituições de acordo com a natureza da medida, ambas, teoricamente, respeitando a criança e o adolescente na condição peculiar de desenvolvimento. ${ }^{74}$

Com o novo modelo, as crianças e adolescentes em situação de vulnerabilidade deveriam ser encaminhados aos abrigos. A medida de natureza protetiva deveria respeitar o caráter excepcional e provisório, não comportando, em regra, privação de liberdade. Os adolescentes que cometeram ato infracional, por sua vez, deveriam ser encaminhados às unidades de cumprimento medida socioeducativa. ${ }^{75}$

Em 2009, foi aprovada a lei 12.010, que passou a adotar a expressão acolhimento institucional. A mudança na nomenclatura traduziu o desejo de romper com as antigas práticas de institucionalização visando priorizar o atendimento a crianças e adolescentes, em caráter excepcional e provisório. Para tanto, a lei limitou a permanência institucional em dois anos (ECA,

\footnotetext{
${ }^{72} \mathrm{Ibid}$.

${ }^{73} \mathrm{Ibid}$

${ }^{74}$ Ibid.

${ }^{75} \mathrm{Ibid}$.
} 
art.19, $\S 2^{\circ}$ ), salvo em casos cuja manutenção represente o melhor interesse da criança, sendo necessário, para tanto, a fundamentação pelo juiz. Garantiu, também, a tramitação prioritária do processo (ECA, art. 152, parágrafo único) e determinou o prazo máximo de 120 dias para a conclusão das ações de suspensão e perda do poder familiar (ECA, art. 163).

Em 2010, a Corregedoria Nacional de Justiça, através da Instrução Normativa $n^{\circ} 02$ de 30 de junho de 2010, previu a realização de audiências concentradas, nas quais o magistrado, junto com a equipe técnica, realizaria o levantamento da situação das crianças e adolescentes em medida protetiva de acolhimento institucional.

Em visita à Casa da Criança, semana anterior à realização da audiência concentrada, no Município de Rio Bonito, foi possível verificar, na narrativa da equipe técnica, os benefícios decorrentes das audiências concentradas. A diretora da instituição falou que o número de crianças e adolescentes se reduziria após a mesma, muitas voltando à convivência familiar e comunitária.

Contudo, segundo a doutora Márcia Fernandes, ex-coordenadora da CDEDICA, a eficácia das audiências ainda é limitada, pois, muitas vezes, quando é realizada a audiência posterior, ainda não foram sanadas as pendências da primeira.

Cabe destacar que o ECA efetivou um Sistema de Garantias de Direitos. Esse sistema é responsável pela definição de responsabilidades no âmbito de atuação na proteção dos direitos e garantias de crianças e adolescentes (ECA. Art. 86 e ss.). Essa política de atendimento é realizada através de um conjunto articulado de ações governamentais e nãogovernamentais, da União, dos Estados, do Distrito Federal e dos Municípios. Esse sistema visa a definição de competência e atuação conjunta entre os diferentes atores. O Estatuto integrou três pilares no 
atendimento às crianças e aos adolescentes: A promoção, a defesa e o controle. $^{76}$

O pilar da promoção oferece serviços em 3 áreas: assistência social, saúde e educação. A assistência social, a partir do Sistema Único de Assistência Social (Suas), principalmente através do Centro de Referência de Assistência Social (Cras), presta serviços nas áreas de vulnerabilidade e risco social. O principal serviço ofertado pelo Cras é o Serviço de Proteção e Atendimento Integral à Família (Paif). ${ }^{77} \mathrm{O}$ Centro de Referência Especializado de Assistência Social (Creas), por sua vez, trabalha com as famílias e indivíduos em situação de ameaça ou violação de direitos. ${ }^{78}$

Na área da saúde, o Sistema Único de Saúde (SUS) objetiva garantir o acesso integral aos cuidados com a saúde, desde de prevenção a tratamentos mais complexos. O SUS apresenta diferentes estruturas, destacando-se: Programa Saúde da Família (PSF); Postos de Saúde; Unidades de Pronto Atendimento ou Pronto-Socorro; Hospitais; Centros de Atenção Psicossocial (Caps). ${ }^{79}$

No segmento da educação é responsabilidade da União, dos Estados, do Distrito Federal e dos Municípios a organização, em cooperação, dos sistemas de ensino. A educação escolar integra a educação básica (formada pela educação infantil, ensino fundamental e ensino médio) e a educação superior. Há, ainda, a educação profissional técnica de nível médio, a educação de jovens e adultos, a educação profissional e tecnológica e a educação superior. ${ }^{80}$

No eixo da proteção é importante destacar a atuação dos serviços de atendimentos socioeducativos, verificada a prática de um ato infracional, tendo a autoridade judiciária aplicado ao adolescente alguma medida socioeducativa (ECA, art. 112). As medidas socioeducativas em meio aberto (III e IV) são executadas em âmbito municipal, enquanto as medidas

\footnotetext{
${ }^{76}$ Ibid.

${ }^{77}$ Ibid.

${ }^{78}$ Ibid.

${ }^{79}$ Disponível em: http://portalsaude.saude.gov.br. Acesso em 11 mai 2015.

${ }^{80}$ Ibid.
} 
de inserção em regime de semiliberdade e internação em estabelecimento educacional (V e VI) são executadas em âmbito estadual. ${ }^{81}$

Atua, ainda, nos serviços de acolhimento institucional sendo essa uma medida provisória e excepcional, objetivando a reintegração familiar ou colocação em família substituta, não se confundindo com medida socioeducativa, pois não comporta, teoricamente, privação de liberdade.

O pilar da defesa, por sua vez, está relacionado a garantia de acesso à Justiça. O eixo é composto pelo Conselho Tutelar (ECA, art. 132), competência de acolher, denunciar, averiguar, encaminhar e orientar todos os casos de violação dos direitos da criança e do adolescente e requisitar serviços públicos nas áreas de saúde, educação, assistência social, previdência, trabalho e segurança (ECA, art. 136); segurança pública, responsável pela atuação na prevenção e no combate a violência, assim como, pela investigação e encaminhamento dos adolescentes em conflito com a lei; a defensoria pública, responsável pela assistência judiciária gratuita, por meio de defensor público ou advogado nomeado, assegurando o acesso à Justiça e garantindo a proteção dos direitos fundamentais das crianças e dos adolescentes e, mais especificamente, dos adolescentes em conflito com a lei. Nesse sentido, o adolescente em conflito com a lei, privado de liberdade, tem direito ao atendimento com periodicidade mínima mensal para fins de ser comunicado sobre sua situação processual e dizer se seus direitos estão sendo respeitados (ECA, art. 124, III e IV), de preferência sem aviso prévio à direção da unidade. A Justiça, correspondendo, principalmente às Varas da Infância e da Juventude e suas equipes multidisciplinares, às Varas Criminais Especializadas, os Tribunais de Justiça, às Comissões Judiciais de Adoção e às Corregedorias Gerais de Justiça; o Ministério Público, ressaltando seu importante papel no exercício da fiscalização das instituições de acolhimento e das unidades de medidas socioeducativas; ouvidoria, espaço reservado às críticas dos cidadãos; centros de defesa responsáveis pela promoção e defesa de direitos de 
crianças e adolescentes através da intervenção jurídico-social, como garantia à proteção integral. Essa proteção é garantida através de intervenções jurídicas, administrativas ou legislativas. ${ }^{82}$

O pilar controle é responsável pela promoção e defesa dos direitos da criança e do adolescente através de discussões realizadas com diferentes integrantes das organizações civis e órgãos governamentais. Dentre os quais destacam-se a atuação dos Conselhos de Direitos, o Conselho Municipal dos Direitos da Criança e do Adolescente e o Conselho Estadual dos Direitos da Criança e do Adolescente. ${ }^{83}$

O objetivo dos Conselhos de Direitos é o acompanhamento, avaliação e monitoramento das ações públicas de promoção e defesa dos direitos das crianças e dos adolescentes. Sua atuação também ocorre através da deliberação prévia de recomendações. Em nível federal, também há o Conselho Nacional dos Direitos da Criança e do Adolescente (Conanda). Essas deliberações devem ser observadas pelos órgãos governamentais e pela sociedade civil organizada. ${ }^{84}$

Nesse eixo estão os Conselhos Setoriais, compostos por representantes do governo e da sociedade civil, com responsabilidade pelo controle de políticas públicas, estabelecendo normas e fiscalizando a prestação de serviços, tanto públicos como privados, dos Municípios. Dentre eles, destacam-se: Conselho Municipal de Assistência Social, Conselho Municipal de Saúde, Conselho Municipal de Educação, Conselho Municipal de Juventude.

\footnotetext{
${ }^{82}$ Ibid.

${ }^{83}$ Ibid.

84 Ibid.
} 


\section{ESTUDOS DOS CASOS DE TORTURA E DEMAIS VIOLAÇÕES DE DIREITOS NAS INSTITUIÇÕES PÚBLICAS DE ACOLHIMENTO DE CRIANÇAS E ADOLESCENTES DO MUNICÍPIO DO RIO DE JANEIRO.}

Andam dizendo que o bem vence o mal Por aqui vou torcendo pra chegar no final É, quanto mais fé, mais religião. A mão que mata, reza, reza ou mata em vão Me contam coisas como se fossem corpos Ou realmente são corpos, todas aquelas coisas

Deixa pra lá, eu devo tá viajando Enquanto eu falo besteira, nego vai se matando.

(Marcelo D2)

\subsection{A Tortura contra Crianças e Adolescentes no Ordenamento Jurídico Brasileiro}

As instituições de acolhimento fazem parte de um cenário de invisibilidade. Quanto menor o grau de visibilidade de um grupo, maiores são as possibilidades de seus direitos serem violados. Dessa forma, conforme relatório da ALERJ e o trabalho de campo realizado com a Defensoria Pública do Rio de Janeiro, constatou-se inúmeras violações aos direitos das crianças e dos adolescentes nesses locais.

O Brasil assinou diversos compromissos internacionais de combate a Tortura, tais como: a Declaração Universal dos Direitos Humanos (1948), o Pacto Internacional dos Direitos Civis e Políticos (1966), a Convenção das Nações Unidas Contra a Tortura e outros Tratamentos ou Penas Cruéis, Desumanos ou Degradantes (1984), a Convenção Interamericana para Prevenir e Punir a Tortura (1985), a Convenção Sobre os Direitos da Criança (1990), Regras Mínimas das Nações Unidas para a Proteção dos Jovens Privados de Liberdade, Regras Mínimas das Nações Unidas para a Administração da Justiça, da Infância e da Juventude (Regras de Beijing);

Diretrizes das Nações Unidas para a Prevenção da Delinquência Juvenil (Diretrizes de RIAD). Além disso, o país foi signatário do Protocolo 
Facultativo à Convenção contra Tortura e Outros Tratamentos ou Penais Cruéis, Desumanos ou Degradantes da Organização das Nações Unidas, ratificado através do Decreto 6.085 de 19 de abril de $2007 .^{85}$

A Declaração Universal dos Direitos Humanos definiu a tortura como crime contra a humanidade. ${ }^{86}$ A Assembleia Geral das Nações Unidas adotou a Convenção contra a Tortura e outros Tratamentos ou Penas Cruéis, Desumanos ou Degradantes, em 1984 e, no ano de 2002, aprovou o Protocolo Facultativo à Convenção contra a Tortura e outros Tratamentos ou Penas Cruéis, Desumanos ou Degradantes, ratificado no Brasil no ano de $2007 .^{87}$

O objetivo do protocolo era implementar a política de visitas regulares por órgãos nacionais e internacionais a locais de privação da liberdade, com o propósito de evitar a tortura e outros tratamentos ou penas cruéis. A instituição de acolhimento é definida no protocolo como espaço de privação de liberdade, conforme definição do inciso 2 do $\operatorname{artigo} 4^{\circ}$ do protocolo. $^{88}$

Para atender a essa finalidade, em 2011, foi criado o Mecanismo Estadual de Prevenção à Tortura, através da Lei 5.778 de 30 de junho de 2010, vinculado à Assembleia Legislativa do Estado do Rio de Janeiro. O Mecanismo tem o objetivo de verificar as condições desses locais e tornálos adequados aos parâmetros nacionais e internacionais. Importante ressaltar a função preventiva do órgão, sendo um de seus objetivos identificar situações de risco capazes violar direitos humanos. ${ }^{89}$

Mediante o exposto, torna-se imperativa a análise do tipo penal da tortura. Em âmbito internacional, a tortura está definida no artigo 1 da

\footnotetext{
${ }^{85}$ RELATÓRIO ANUAL DO MECANISMO ESTADUAL DE PREVENÇÃO E COMBATE À TORTURA DO RIO DE JANEIRO 2012

${ }^{86}$ Declaração Universal dos Direitos Humanos artigo V.

${ }^{87}$ RELATÓRIO ANUAL DO MECANISMO ESTADUAL DE PREVENÇÃO E COMBATE À TORTURA DO RIO DE JANEIRO 2012

${ }^{88}$ qualquer forma de detenção ou aprisionamento ou colocação de uma pessoa em estabelecimento público ou privado de vigilância, de onde, por força de ordem judicial, administrativa ou outra autoridade, ela não tem permissão para ausentar-se por sua própria vontade".

${ }^{89}$ RELATÓRIO ANUAL DO MECANISMO ESTADUAL DE PREVENÇÃO E COMBATE À TORTURA DO RIO DE JANEIRO 2012
} 
Convenção Contra a Tortura e outros Tratamentos ou Penas Cruéis, Desumanos ou Degradantes, como:

\begin{abstract}
Para fins da presente Convenção, o termo "tortura" designa qualquer ato pelo qual dores ou sofrimentos agudos, físicos ou mentais, são infligidos intencionalmente a uma pessoa a fim de obter, dela ou de terceira pessoa, informações ou confissões; de castigá-la por ato que ela ou terceira pessoa tenha cometido ou seja suspeita de ter cometido; de intimidar ou coagir esta pessoa ou outras pessoas; ou por qualquer motivo baseado em discriminação de qualquer natureza; quando tais dores ou sofrimentos são infligidos por um funcionário público ou outra pessoa no exercício de funções públicas, ou por sua instigação, ou com o seu consentimento ou aquiescência. Não se considerará como tortura as dores ou sofrimentos que sejam consequência unicamente de sanções legítimas, ou que sejam inerentes a tais sanções ou delas decorram.
\end{abstract}

No Brasil, a Constituição Federal em seu artigo, 5, III, proíbe a submissão da pessoa à tortura ou a tratamento desumano ou degradante". O inciso XLIII, do mesmo dispositivo constitucional, determina a tortura como crime hediondo, inafiançável, insuscetível de graça ou anistia, por ela respondendo os mandantes, os executores e os que podendo evitá-la se omitirem.

A tortura anula a própria condição de dignidade da existência humana, tornando o indivíduo objeto nas mãos do torturador. Por essa razão, esse crime demonstra uma forma drástica de barbárie, sendo inadmissível sua existência num Estado democrático de direito.

O crime de tortura está tipificado na Lei 9.455/1997, art. $1^{\circ}$. Em relação ao sujeito ativo, a legislação brasileira se difere da internacional ao permitir o particular, sem prejuízo do representante do Estado, enquanto a internacional prevê, exclusivamente, o agente estatal. Contudo, é prevista a causa de aumento de pena pela especial circunstância de ser agente público (Lei $9455 / 97 \operatorname{art.1}^{\circ}, \S 4^{\circ}, \mathrm{I}$ ). Isso ocorre, pois o bem jurídico do regular funcionamento da administração pública é lesado, além da integridade física e da dignidade humana. No entanto, é necessário que o sujeito tenha se valido da condição de agente público, no exercício ou não da função. ${ }^{90}$

Essa opção legislativa tem a crítica de parcela da doutrinária por considerá-la incompatível com os objetivos da Convenção. O entendimento

\footnotetext{
${ }^{90}$ CAPEZ, Curso de Direito Penal-Legislação Penal Especial, p. 673.
} 
é de que o tipo penal visa proteger os indivíduos contra a arbitrariedade do Estado, nesse sentido leciona Flávia Piovesan:

\begin{abstract}
Parece mais adequada a definição da Convenção, ainda que mais ampla se mostre a definição nacional. Isto porque a gravidade da tortura e o fato de ser ela considerada crime contra a ordem internacional justifica-se na medida em que sua prática revela a perversidade do Estado que, de garante de direitos, passa a ter em seus agentes brutais violadores de direitos. (Flávia Piovesan. Direitos Humanos e o Direito Constitucional Internacional, cit. p. 204.)
\end{abstract}

O penalista Silva Franco defende a inconstitucionalidade do alargamento do sujeito ativo, uma vez que a Convenção contra a Tortura é tratado internacional de direitos humanos, ingressando no ordenamento jurídico com status de norma constitucional $\left(\mathrm{CF}\right.$, art. $\left.5^{\circ}, \S 3^{\circ}\right)$. Dessa forma, não poderia a lei ordinária alargar a abrangência do tipo. ${ }^{91}$ Em sentido contrário, outros doutrinadores como Nucci e Junqueira, defendem a maior abrangência, sem a necessidade do sujeito ativo ser um agente do Estado, pois assim haveria uma maior proteção da dignidade humana. ${ }^{92}$

Para caracterizar a tortura é necessário que o sofrimento seja ilegítimo. A medida protetiva de acolhimento institucional, por exemplo, pode gerar sofrimento em razão da falta de convivência familiar, mesmo assim não será considerada tortura, pois tem previsão legal. Entretanto, da análise do caso concreto, podem ser observados se fatores como a superlotação, condições insalubres, violência física e psicológica, configurariam grave suplício ilegítimo.

$\mathrm{O}$ art. 233 do Estatuto da Criança e do Adolescente previa o crime de tortura contra a criança e o adolescente, mas não o definia. O Estatuto ao fazer essa previsão deu efetividade aos tratados internacionais e ao princípio da proteção integral (CF, art. 227). Todavia, parcela da doutrina, como Alberto Silva Franco, dizia inconstitucional tal dispositivo por ferir o

\footnotetext{
${ }^{91}$ FRANCO, Alberto Silva. Leis Penais Especiais e sua Interpretação Jurisprudencial. São Paulo: RT, 2002, v.II., p. 172.

${ }^{92}$ NUCCI, Guilherme de Souza. Leis Penais e Processuais Penais Comentadas, volume 2, p. 684. Total de páginas 748. Junqueira, Gustavo Octaviano. Legislação Penal Especial volume 2, 3. Ed.São Paulo: Saraiva 2010. pp. 593-619.
} 
princípio da legalidade, uma vez que não trazia o conceito de tortura, sendo uma norma penal aberta. ${ }^{93}$

Não obstante o entendimento supracitado, o STF no julgamento do HC 70389 / SP - SÃO PAULO, 23/06/1994, entendeu, em votação apertada $(6 \times 5)^{94}$, pela constitucionalidade. Contudo, a Lei 9955/97, artigo $1^{\circ}, \S 4^{\circ}$, II revogou o artigo 233 do ECA colocando fim a discussão.

\footnotetext{
${ }^{93}$ FERNANDES, Antonio Scarance, Aspectos da Lei dos Crimes Hediondos, Justiça Penal, p. 82.

${ }^{94}$ E M E N T A: TORTURA CONTRA CRIANÇA OU ADOLESCENTE - EXISTÊNCIA JURÍDICA DESSE CRIME NO DIREITO PENAL POSITIVO BRASILEIRO - NECESSIDADE DE SUA REPRESSÃO - CONVENÇÕES INTERNACIONAIS SUBSCRITAS PELO BRASIL PREVISÃO TÍPICA CONSTANTE DO ESTATUTO DA CRIANÇA E DO ADOLESCENTE (LEI N ${ }^{\circ}$ 8.069/90, ART. 233) - CONFIRMAÇ̃̃O DA CONSTITUCIONALIDADE DESSA NORMA DE TIPIFICAÇÃO PENAL - DELITO IMPUTADO A POLICIAIS MILITARES INFRAÇÃO PENAL QUE NÃO SE QUALIFICA COMO CRIME MILITAR - COMPETÊNCIA DA JUSTIÇA COMUM DO ESTADO-MEMBRO - PEDIDO DEFERIDO EM PARTE. PREVISÃO LEGAL DO CRIME DE TORTURA CONTRA CRIANÇA OU ADOLESCENTE OBSERVÂNCIA DO POSTULADO CONSTITUCIONAL DA TIPICIDADE. - O crime de tortura, desde que praticado contra criança ou adolescente, constitui entidade delituosa autônoma cuja previsão típica encontra fundamento jurídico no art. 233 da Lei $n^{\circ} 8.069 / 90$. Trata-se de preceito normativo que encerra tipo penal aberto suscetível de integração pelo magistrado, eis que o delito de tortura - por comportar formas múltiplas de execução - caracteriza- se pela inflição de tormentos e suplícios que exasperam, na dimensão física, moral ou psíquica em que se projetam os seus efeitos, o sofrimento da vítima por atos de desnecessária, abusiva e inaceitável crueldade. - A norma inscrita no art. 233 da Lei $\mathrm{n}^{\circ} 8.069 / 90$, ao definir o crime de tortura contra a criança e o adolescente, ajusta-se, com extrema fidelidade, ao princípio constitucional da tipicidade dos delitos (CF, art. $5^{\circ}$, XXXIX). A TORTURA COMO PRÁTICA INACEITÁVEL DE OFENSA À DIGNIDADE DA PESSOA. A simples referência normativa à tortura, constante da descrição típica consubstanciada no art. 233 do Estatuto da Criança e do Adolescente, exterioriza um universo conceitual impregnado de noções com que o senso comum e o sentimento de decência das pessoas identificam as condutas aviltantes que traduzem, na concreção de sua prática, o gesto ominoso de ofensa à dignidade da pessoa humana. A tortura constitui a negação arbitrária dos direitos humanos, pois reflete - enquanto prática ilegítima, imoral e abusiva - um inaceitável ensaio de atuação estatal tendente a asfixiar e, até mesmo, a suprimir a dignidade, a autonomia e a liberdade com que o indivíduo foi dotado, de maneira indisponível, pelo ordenamento positivo. NECESSIDADE DE REPRESSÃO À TORTURA - CONVENÇÕES INTERNACIONAIS. - O Brasil, ao tipificar o crime de tortura contra crianças ou adolescentes, revelou-se fiel aos compromissos que assumiu na ordem internacional, especialmente àqueles decorrentes da Convenção de Nova York sobre os Direitos da Criança (1990), da Convenção contra a Tortura adotada pela Assembléia Geral da ONU (1984), da Convenção Interamericana contra a Tortura concluída em Cartagena (1985) e da Convenção Americana sobre Direitos Humanos (Pacto de São José da Costa Rica), formulada no âmbito da OEA (1969). Mais do que isso, o legislador brasileiro, ao conferir expressão típica a essa modalidade de infração delituosa, deu aplicação efetiva ao texto da Constituição Federal que impõe ao Poder Público a obrigação de proteger os menores contra toda a forma de violência, crueldade e opressão (art. 227, caput, in fine). TORTURA CONTRA MENOR PRATICADA POR POLICIAL MILITAR - COMPETÊNCIA DA JUSTIÇA COMUM DO ESTADO-MEMBRO. - O policial militar que, a pretexto de exercer atividade de repressão criminal em nome do Estado, inflige, mediante desempenho funcional abusivo, danos físicos a menor eventualmente sujeito ao seu poder de coerção, valendo-se desse meio executivo para intimidá-lo e coagi-lo à confissão de determinado delito, pratica, inequivocamente, o crime de tortura, tal como tipificado pelo art. 233 do Estatuto da Criança e do Adolescente, expondo-se, em função desse comportamento arbitrário, a todas as consequiências jurídicas que decorrem da Lei $\mathrm{n}^{\circ} 8.072 / 90$ (art. $2^{\circ}$ ), editada com fundamento no art. $5^{\circ}$, XLIII, da Constituição. - O crime de tortura contra criança ou adolescente, cuja prática absorve o delito de lesões corporais leves, submete-se à competência da Justiça comum do Estado-membro, eis que
} 
Em razão da especial vulnerabilidade, quando praticada contra crianças e adolescentes, a Lei de Tortura prevê a causa de aumento de pena (Lei $9455 / 97 \operatorname{art}^{\circ} 1^{\circ} \S 4^{\circ}, \mathrm{II}$ ). Dessa forma, afasta a agravante do Código Penal (CP. art. 61, h), sob pena de bis in idem.

Os tipos penais de tortura e maus-tratos apresentam diferenças nos aspectos objetivos e subjetivos, ou seja, no resultado provocado na vítima e no dolo do agente. Na tortura há grave sofrimento e o dolo é de dano; nos maus tratos não há imposição de grave sofrimento e o dolo é de perigo. ${ }^{95}$

\subsection{Estudo de Caso da Central de Triagem Taiguara}

A lei 8.099/90 determina, conforme artigo 88, I, a municipalização como diretriz da política de atendimento de crianças e adolescentes.

A Central Taiguara é uma unidade de triagem de crianças e adolescentes do sexo feminino e de crianças do sexo masculino. No ano de 2012, a unidade tinha capacidade máxima de 15 e 25 crianças e adolescentes, tendo média flutuante entre 15 a $25 .{ }^{96}$

No dia 08 de maio de 2013, a Coordenadoria de Defesa dos Direitos da Criança e do Adolescente da Defensoria Pública (CDEDICA) compareceu na Central de Recepção Taiguara, acompanhada da Coordenadoria Geral de Serviço Social e Psicologia da Defensoria Pública do Estado do Rio de Janeiro, para atender uma adolescente, na qualidade de curadora especial, nomeada pelo Juízo da Infância Regional de Madureira. ${ }^{97}$

No final da visita diversas crianças relataram a violência física sofrida por parte de alguns "educadores sociais", dentre os nomes citados estavam o da educadora conhecida como Xuxa, além de Jorge e Jeferson.

esse ilícito penal, por não guardar correspondência típica com qualquer dos comportamentos previstos pelo Código Penal Militar, refoge à esfera de atribuições da Justiça Militar estadual.(HC 70389, Relator(a): Min. SYDNEY SANCHES, Relator(a) p/ Acórdão: Min. CELSO DE MELLO, Tribunal Pleno, julgado em 23/06/1994, DJ 10-08-2001 PP-00003 EMENT VOL-0203802 PP-00186)

${ }_{95}$ JUNQUEIRA, Gustavo Octaviano Diniz. Legislação penal especial, volume 2, 2008, p.422.

${ }^{96}$ Relatório da Coordenadoria de defesa dos direitos da criança e do adolescente sobre a Central de Recepção de Crianças e Adolescentes Taiguara.

${ }^{97}$ Relatório da Coordenadoria de defesa dos direitos da criança e do adolescente sobre a Central de Recepção de Crianças e Adolescentes Taiguara. 
Uma das adolescentes, quando a defensora prometeu que tomaria providencias, descrente, perguntou para quantas era falada a mesma história. $^{98}$

A CDEDICA entrou em contato com o delegado da Delegacia de Proteção à Criança e ao Adolescente (DPCA), Marcelo Braga Maia e, encaminhou ofício relatando o atendimento e solicitando que as crianças fossem ouvidas, tendo sido registrada ocorrência sob o número 94700294/2013. ${ }^{99}$

No mesmo dia, por volta das 18:00h, a Defensoria Pública, através da CDEDICA, retornou à Central Taiguara, quando já estavam no local o conselheiro tutelar do Centro, que havia sido comunicado dos relatos sobre violência contra as crianças, conforme prevê o artigo 13 do Estatuto da Criança e do Adolescente, bem como os policiais e delegado da DCAV. ${ }^{100}$

Compareceram, também ao local, o Subsecretário de Proteção Social Especial Rodrigo Abel, a assessora da Subsecretaria Municipal de Assistência, Maria Domingas, a coordenadora da $1^{\text {a }}$ CAS, Maria de Fátima, também se encontrando presentes a coordenadora da Central Taiguara e uma psicóloga da entidade. No mesmo dia foram colhidos, pela DCAV, declarações de sete crianças e adolescentes acolhidos. ${ }^{101}$

No dia 10 de maio de 2013, foi encaminhado, pelo Conselho Tutelar do Centro, relatório sobre a visita realizada pelo Órgão de Proteção ao Juízo da Infância, da Juventude e do Idoso da Capital. ${ }^{102}$

No dia 13 de maio de 2013, a Coordenadoria de Defesa dos Direitos da Criança e do Adolescente, da Defensoria Pública, protocolou na Vara da Infância, da Juventude e do Idoso da Capital medida cautelar inominada, distribuída sob o número 0159367-04.2013.8.19.0001, em que foram

\footnotetext{
${ }^{98}$ Nota Pública da Coordenadoria de defesa dos direitos da criança e do adolescente sobre a Central de Recepção de Crianças e Adolescentes Taiguara.

${ }^{99}$ Ibid.

${ }^{100}$ Ibid.

${ }^{101}$ Ibid.

${ }^{102}$ Relatório da Coordenadoria de defesa dos direitos da criança e do adolescente sobre a Central de Recepção de Crianças e Adolescentes Taiguara.
} 
solicitadas várias medidas, inclusive, o afastamento dos funcionários apontados como agressores. ${ }^{103}$

Não obstante, a Defensoria Pública expediu ofícios a diversos órgãos do Sistema de Garantia de Direitos, tais como Conselho Nacional, Estadual e Municipal de Direitos da Criança, Secretaria Nacional de Promoção dos Direitos da Criança e do Adolescente, UNICEF e Ministério do Desenvolvimento Social, comunicando o ocorrido e as medidas tomadas. ${ }^{104}$

Posteriormente, foi proposta pelo Ministério Público, ação civil pública pedindo afastamento da direção da Central de Recepção Taiguara e dos funcionários da TESLOO. ${ }^{105}$

No dia 21 de maio do mesmo ano, a Coordenadoria de Defesa dos Direitos da Criança e do Adolescente realizou nova visita à Central de Recepção Taiguara, verificando que o número de crianças e adolescentes acolhidos na Central havia reduzido, tendo assumido nova direção no dia anterior (Maria Célia Vasconcellos); pequenas mudanças na estrutura física haviam sido feitas, tendo sido informada transferência dos educadores apontados como autores dos crimes contra os acolhidos e novos educadores assumiram em razão do Convênio com a ONG Tesloo. ${ }^{106}$

No dia 31 de julho de 2013, foi distribuída ação civil pública pleiteando o fechamento da Central de Recepção Taiguara tendo em vista as péssimas condições de funcionamento, sob $\mathrm{o} \quad \mathrm{n}^{\circ}$ 026141978.2013.8.19.0001. ${ }^{107}$

Ainda em 2013, a CDEDICA recebeu a notícia de que uma adolescente teria sido vítima de estupro, no interior da Central de Recepção Taiguara, entre o dia 21 e 22 de junho. Tal fato ensejou a abertura do inquérito RO 903-00484/2013. O inquérito tramitou na DPCA tendo sido

\footnotetext{
${ }^{103}$ Relatório da Coordenadoria de defesa dos direitos da criança e do adolescente sobre a Central de Recepção de Crianças e Adolescentes Taiguara.

104 Ibid.

${ }^{105}$ http://noticias.terra.com.br/brasil/cidades/mp-rj-pede-afastamento-de-diretora-de-abrigoda-prefeitura,234805ebad4be310VgnVCM4000009bcceb0aRCRD.html

${ }^{106}$ Processo nº261419-78.2013.8.19.0001

107 Nota Pública da Coordenadoria de defesa dos direitos da criança e do adolescente sobre a Central de Recepção de Crianças e Adolescentes Taiguara.
} 
encaminhado Nota Pública da Coordenadoria de Defesa dos Direitos da Criança e do Adolescente sobre a Central de Recepção de Crianças e Adolescentes Taiguara.

Em visita, realizada no dia 25 de fevereiro de 2015, conforme fotos em anexo (foto 6 , anexo 5), foi possível verificar que a estrutura física da Instituição se encontra em boas condições. No andar superior tinham os quartos coletivos separados por sexo e faixa etária. Os banheiros apresentavam condições adequadas para higiene pessoal. Os banheiros para banho tinham chuveiros quentes e eram separados por sexo. Tanto os quartos, como a sala de televisão tinham ventiladores. ${ }^{108}$

Atualmente o estabelecimento tem a capacidade para atender, no máximo, 20 crianças e adolescentes. Sua finalidade é a triagem de crianças e adolescentes do sexo feminino e de crianças de ambos os sexos. No momento da visita a casa tinha o total de 15 crianças e adolescentes, 13 estavam num passeio, pois uma adolescente, com sua filha de 2 meses, ficou na casa. ${ }^{109}$

Importante destacar que, embora a atual Central de Recepção Taiguara se encontre em condições adequadas de funcionamento, as vítimas da antiga Taiguara, que tiveram seus direitos violados, continuam sem qualquer resposta do Estado. Os educadores sociais envolvidos na situação foram apenas transferidos para outras instituições. ${ }^{110}$

Em relação ao estupro de vulnerável, apenas no 20/02/2015, o Ministério Público ofereceu denúncia em face do educador social A. L. B. da C. O processo de número 00511274720158190001 , tramita na $29^{a}$ Vara Criminal, tendo a denúncia sido recebida, no dia 02/03/2015. ${ }^{111}$

\subsection{Estudo de Caso do Centro de Acolhimento Ayrton Sena}

\footnotetext{
${ }^{108}$ Visita realizada no dia 25.02.2015.

${ }^{109}$ Visita realizada no dia 25.02.2015.

${ }^{110}$ Visita realizada no dia 25.02.2015.

${ }^{111}$ RO 903-00484/2013 que originou o processo de número 00511274720158190001.
} 
O Centro de Acolhimento Ayrton Senna é uma instituição de responsabilidade do Município do Rio de Janeiro, tendo por objetivo a assistência material e psicológica de crianças e adolescentes afastadas da convivência familiar. ${ }^{112}$

Segundo a Secretaria Municipal de Assistência Social é a maior unidade de atendimento do Município do Rio de Janeiro. Sua capacidade é de 122 (cento e vinte e duas) crianças e adolescentes, sendo que atende aproximadamente 100, em total dissonância com os princípios do Estatuto da Criança e Adolescente. ${ }^{113}$

Nesse sentido, há um grande problema, pois, a Resolução $n^{\circ} 01$ do CNAS/CONANDA afirma expressamente que o número máximo de crianças e adolescentes por instituição é o de 20 (vinte).

Outra questão relevante é que a mesma Resolução determina que as instituições de acolhimento mantenham os aspectos arquitetônicos semelhantes às das residências da comunidade em que estão inseridas. A referida instituição, no entanto, destoa das demais casas da localidade.

Vários são os motivos para os problemas da Ayrton Sena, dentre os quais, conforme informado pela própria Secretaria Municipal de Assistência Social, no ofício 180/2010, enviado à Defensoria Pública, a instituição foi originalmente concebida para o atendimento a adolescentes em conflito com a lei, na época do denominado CERIM. ${ }^{114}$ Em razão do novo paradigma constitucional da proteção integral, tal estrutura é inadmissível, inclusive, para as unidades de internação. ${ }^{115}$

A supracitada instituição, após vistorias, foi objeto de medidas administrativas e advertências por parte do Judiciário. Todavia, contrariando o princípio da prioridade absoluta, consagrado no artigo 227 da Constituição Federal, a instituição continuou acolhendo crianças e adolescente mesmo sem as condições adequadas de funcionamento.

\footnotetext{
112 Relatório da Coordenadoria de defesa dos direitos da criança e do adolescente sobre a Instituição de Acolhimento Ayrton Sena.

${ }_{113}^{13}$ Ibid.

${ }^{114}$ Fls. 62/72 do processo cautelar 0151341-85.2011.8.19.0001.

${ }^{115}$ Ibid.
} 
Nessa seara, foi instaurada a Portaria Verificatória de Irregularidade de Atendimento (0233998-21.2010.8.19.0001) para investigar as graves irregularidades apontadas pelo Serviço de Integração de Entidades de Acolhimento - SINEATE. ${ }^{116}$

Ao longo do procedimento foram realizadas inúmeras vistorias que demonstraram a insuficiência do número de educadores sociais, inadequação das formas de atendimento às crianças, graves problemas nas instalações elétricas, com perigo iminente de incêndio generalizado nas instalações, sofás com pregos aparentes, alimentos vencidos, entre outras questões que mostram as péssimas condições que estavam vivendo esses indivíduos (anexo 4, fotos 7-9). ${ }^{117}$

Após a realização dessas vistorias, o comissariado concluiu, expressamente, que a instituição precisaria de uma reforma geral, principalmente nas casas onde ficam as crianças e adolescentes. Contudo, o município se manteve inerte não cumprindo a determinação judicial estabelecida, limitando-se a alegar a reserva do possível em razão da insuficiência orçamentária. Alegou, ainda, que o problema era em razão da administração anterior. ${ }^{118}$

Após nova inspeção do comissariado foi verificada a manutenção das irregularidades na instituição de acolhimento. Entretanto, com o argumento superficial acerca do aumento na quantidade de vans e de educadores sociais, o Ministério Público peticionou, ao Juízo, o cancelamento da audiência especial, bem como, o envio, pela Secretaria Municipal de Assistência Social, do cronograma das obras. ${ }^{119}$

Nos relatórios das vistorias foram apontadas violações ao direito constitucional à identidade. Os comissários relataram que as crianças e adolescentes acolhidos não possuíam seus próprios objetos, pois havia um

\footnotetext{
${ }^{116}$ Portaria Verificatória de Irregularidade de Atendimento número 0233998-21.2010.8.19.0001. Fl. 23.

${ }^{117}$ Ibid.

118 Ação Civil Pública com Pedido Liminar de Efeitos da Tutela, processo 023052204.2012.8.19.0001.

119 Relatório da Coordenadoria de defesa dos direitos da criança e do adolescente sobre a Instituição de Acolhimento Ayrton Sena.
} 
compartilhamento generalizado de roupas, sapatos, materiais de higiene e demais itens pessoais. Conforme relatado no capítulo primeiro, a construção da individualidade é essencial num espaço de acolhimento. ${ }^{120}$

Nesse sentido, a CDEDICA propôs em maio de 2011, simultaneamente ao curso da Portaria, ação cautelar de produção antecipada de provas (0151341-85.2011.8.19.0001), com o objetivo de reunir elementos de convicção para comprovar a situação degradante do Centro de Acolhimento Ayrton Senna. Na ocasião foi deferida a inspeção judicial na unidade. $^{121}$

No curso do processo cautelar várias provas foram colhidas, mas uma em especial merece destaque. Segundo relatou o oficial de justiça avaliador, as crianças do dormitório da casa 05 , de 4 a 6 anos, no total de 10, apresentaram um comportamento bastante incomum, estavam todas dormindo em sono profundo. A inspeção durou até às $14 \mathrm{~h}$, e nenhuma criança havia acordado, algumas nem mudado de posição, apesar da tentativa do oficial de justiça e da analista judiciária de tentarem acordálas. $^{122}$

Em razão da situação apresentada, a CDEDICA ingressou, em junho de 2012, com a Ação Civil Pública com Pedido Liminar de Efeitos da Tutela (Processo 0230522-04.2012.8.19.0001), em face do Município, pleiteando a extinção da instituição, assegurando aos adolescentes e crianças transferência para instituições de acolhimento que tivessem as condições dignas de atendimento. Entende-se por condições dignas o respeito às diretrizes estabelecidas pelo CONANDA. ${ }^{123}$

No dia 28 de junho de 2012, o Judiciário determinou a remessa dos autos à Secretaria Municipal de Assistência Social, aos cuidados da subsecretária Mônica Blum, para que sanasse todas as questões apontadas, no prazo de 30 dias. Após esse prazo, deveria ser comunicado ao Juízo as

\footnotetext{
${ }^{120}$ Portaria Verificatória de Irregularidade de Atendimento número 0233998-21.2010.8.19.0001.

${ }^{121}$ Ibid.

${ }^{122}$ Processo: 0151341-85.2011.8.19.0001.Fl. 58.

${ }^{123}$ Ibid.
} 
reformas realizadas. Caso não cumpridas as determinações, deveria ser encaminhado ofício justificando a impossibilidade. ${ }^{124}$

No dia 18 de dezembro de 2012, foi verificado que o Centro de Acolhimento Ayrton Sena estava com sérios problemas de fornecimento de água, em razão dos defeitos na bomba, submetendo as crianças e adolescentes acolhidos a dificuldades de satisfação de necessidades básicas de higiene. Em razão da elevada temperatura dessa época do ano, as crianças e adolescentes foram levadas a tomar banho no zoológico do Grajaú. ${ }^{125}$

No dia 04 de novembro de 2013, foi necessário a Defensoria reiterar o pedido de antecipação de tutela, pois o mesmo, protocolado em julho de 2012, ainda não havia sido apreciado. Percebe-se, portanto, a total indiferença do Judiciário com as questões suscitadas. ${ }^{126}$

Atualmente, 3 anos após as vistorias e abordagens apresentadas, o Centro de Acolhimento Ayrton Sena continua com os mesmos problemas. A ação civil pública ainda tramita. O Judiciário, mais uma vez, demonstra sua total incapacidade para aplicar o princípio da proteção integral, consagrado no artigo 227 da Constituição Federal. Não obstante, as políticas públicas municipais voltadas a infância se socorrem da reserva do possível com o objetivo de descumprirem a determinação legal, disposta no ECA e na Resolução ${ }^{\circ} 01$ do CONANDA. ${ }^{127}$

$\mathrm{Na}$ contramão das alegações do Município, cumpre analisar que a Teoria da Reserva do Possível surgiu na Alemanha, país cujos direitos fundamentais foram efetivados. No Brasil, a teoria é frequentemente utilizada como escusa à implementação desses direitos. Não há dúvidas de que o orçamento tem limites, contudo, questiona-se a prioridade na sua

\footnotetext{
${ }^{124}$ Relatório da Coordenadoria de defesa dos direitos da criança e do adolescente sobre a Instituição de Acolhimento Ayrton Sena.

${ }^{125}$ Portaria Verificatória do Juízo da Vara da Infância, da Juventude e do Idoso da Capital, conforme petição protocolada em dezembro de 2012, referente à visita realizada em 18 de dezembro de 2012.

${ }^{126}$ Relatório da Coordenadoria de Defesa dos Direitos da Criança e do Adolescente sobre a Instituição de Acolhimento Ayrton Sena.

${ }^{127}$ Entrevista realizada com a coordenadora Eufrásia Souza das Virgens, no dia 25/02/2015. No mesmo sentido respondeu o desembargador Siro Darlan no dia 26/05/215.
} 
utilização. Vislumbra-se, assim, que a questão se apresenta no campo das escolhas e, não, necessariamente, nos limites do orçamento. Nesse sentido, leciona Canotilho:

$\mathrm{O}$ entendimento dos direitos sociais econômicos e culturais como direitos originários implica, como já foi salientado, uma mudança na função dos direitos fundamentais e põe como acuidade o problema de sua efectivação. Não obstante se falar aqui da efectivação dentro de uma 'reserva possível', para significar a dependência dos direitos económicos, sociais e culturais dos 'recursos econômicos' a efetivação dos direitos econômicos sociais e culturais não se reduz a um simples 'apelo' ao legislador. Existe uma verdadeira imposição constitucional, legitimadora, entre outras coisas, de transformações econômicas e sociais na medida em que estas forem necessárias para efetivação desses direitos. ${ }^{128}$

As decisões do STF são no sentido do dever do Poder Judiciário, excepcionalmente, determinar que as políticas públicas estabelecidas na Constituição Federal sejam implementadas sempre que os órgãos responsáveis pelas mesmas fiquem inertes. Cabe destacar as palavras do ilustre ministro Celso de Mello:

Cumpre advertir, desse modo, que a cláusula da "reserva do possível" ressalvada a ocorrência de justo motivo objetivamente aferível - não pode ser invocada, pelo Estado, com a finalidade de exonerar-se, dolosamente, do cumprimento de suas obrigações constitucionais, notadamente quando, dessa conduta governamental negativa, puder resultar nulificação ou, até mesmo, aniquilação de direitos constitucionais impregnados de um sentido de essencial fundamentalidade. ${ }^{129}$

Distorcer o significado da reserva do possível para fins de negar os direitos fundamentais da infância e da adolescência se mostra ainda mais cruel em razão da condição peculiar de pessoa em desenvolvimento dos sujeitos atingidos. Cabendo, portanto, ao Judiciário determinar a implementação

$\operatorname{dos}$

mesmos.

\footnotetext{
${ }^{128}$ CANOTILHO, José Joaquim Gomes. Direito constitucional e teoria da constituição. 3. ed. Coimbra: Almedina, 1999.p. 448.

129 ADPF 45/DF, Rel. Min. CELSO DE MELLO, proferi decisão assim ementada (Informativo/STF n ${ }^{\circ} 345 / 2004$ ).
} 


\section{DA INSTITUIÇÃO DE ACOLHIMENTO AO SOCIOEDUCATIVO: A APLICAÇÃO ANÁLOGA DO PRINCÍPIO DA COCULPABILIDADE}

"O menino acabara de chegar na Febem, dentro de um camburão. Depois de um susto, uma senhora se aproximou dele. Pela primeira vez na vida um adulto colocava a mão no joelho daquela criança e pedia licença pra falar com ela. Na Febem, isso não acontecia. Logo, o menino pensou: ih, essa mulher quer me bater. Mas ela disse, com sotaque carregado: eu gostarrrria de falarrrr com você.

Ele ficou paralisado e disse que morria de pena, pois ela falava tudo errado, certamente tinha língua presa. Ela riu e disse que onde morava todos falavam assim. Imediatamente o menino retrucou: ah, sei, como os leprosos! E ela disse que não, que morava do outro lado do planeta, que a terra era redonda, que enquanto aqui era de dia, lá na França era noite.

O menino pensou que ela era doida mesmo e fugiu. Três dias depois se reencontraram em uma rua em Belo Horizonte. Ela gritava: Robertô, Robertô! E ele pensou: meu Deus, lá vem a doida francesa. Mas viu que ela tinha um relógio de ouro e decidiu assaltá-la. Mas ela pediu que ele ficasse em uma semana em sua casa, pois ela precisava gravar uma entrevista.

Imediatamente o menino pensou que poderia roubar outras coisas: videocassete, televisão e dinheiro. E começou a aprender francês, enquanto ensinava para ela a língua dos meninos de rua, algo assim como a língua do pê. Pela primeira vez, alguém pedia que o menino, que tinha treze anos, ensinasse algo. As conversas eram mais ou menos assim: ela dizia vopêcêpê espêtápê bempê? e ele respondia: Oui, madamme!

Os dias foram passando e ele decidiu que só roubaria a televisão e o dinheiro. Depois, só o dinheiro. E ela, que era casada e voltaria à França em uma semana, ia se esquecendo da viagem de volta. Marguerite - esse era seu nome - renovou o visto de permanência no Brasil por duas vezes e, um ano depois de encontrar o menino, ela conseguiu sua guarda oficialmente. E alguns anos depois, o menino irrecuperável que chegava à Febem se transformou em um professor. Este menino sou eu"

Roberto Carlos Ramos

Existem muitos Robertos no sistema socioeducativo. Entretanto, poucas Marguerites. Invisíveis no acolhimento institucional, dados como 
irrecuperáveis e altamente perigosos, crianças e adolescentes são jogados pelo Estado, com a permissão da sociedade, na marginalidade. Com passagens por instituições de acolhimento e unidades de medidas socioeducativas, cada vez são maiores os muros que separam esses "menores" dos "adolescentes".

Nesse sentido, o presente capítulo abordará o estudo dos casos concretos de três adolescentes. A Fernanda (nome fictício) com passagem pelo acolhimento institucional no Centro de Acolhimento Ayrton Sena e, atualmente, cumprindo medida socioeducativa na Santos Dumont e, os adolescentes Bruno e Mateus (nomes fictícios), com passagens por algumas instituições de acolhimento, com destaque para a Central de Triagem Carioca. Os meninos estão cumprindo internação provisória, no Dom Bosco, mais conhecido como Padre Severino, aguardando a audiência.

Analisando a transição entre as duas medidas, protetiva e socioeducativa, será trabalhada a aplicação análoga do conceito de coculpabilidade às medidas socioeducativas. Nesses casos as medidas socioeducativas de internação e semiliberdade não exercem suas funções. Os adolescentes oriundos do acolhimento institucional reconhecem no sistema socioeducativo apenas uma continuação do processo anteriormente iniciado, ou seja, de exclusão da sociedade.

A escolha pela adolescente do sexo feminino, revela-se de grande importância, uma vez que nesse ano de 2015 está sendo discutida a diminuição da maioridade penal. Contudo, em todas as discussões, o cenário é composto por adolescentes do sexo masculino. Os sofrimentos das meninas são sufocados pelo discurso de histeria. Não obstante, são elas as que mais sofrem as consequências da medida de internação, decorrentes do abandono afetivo, da maternidade e das condições precárias.

Dessa forma, será trabalhada a institucionalização sob a perspectiva da adolescente e dos adolescentes que circulam entre os dois sistemas, sem prejuízo da oitiva da equipe técnica responsável. Cumpre salientar que os casos analisados são apenas representações de um universo de significados. 
Importante destacar que a adolescente e os adolescentes foram apontadas, pelas equipes técnicas, como exemplos de completa institucionalização. Sem qualquer triagem a respeito das instituições de acolhimento, foram selecionados a menina e os meninos, respectivamente, com passagem pelo Ayrton Sena e pela Carioca. Ambas instituições apontadas no presente trabalho como violadoras dos direitos fundamentais.

Não obstante a relevância dessa questão, não existem dados oficiais sobre o assunto. $\mathrm{O}$ silêncio não é uma simples ausência, mas um descaso. Esses sujeitos estão envolvidos em toda uma rede de invisibilidade. Suas vidas pouco ou nada valem para o Estado e para a sociedade. No mais, a apresentação dessa problemática, em estatísticas, pode revelar a total falência do Estado brasileiro em relação a infância.

\subsection{A Culpabilidade, a Inimputabilidade Biológica e a Coculpabilidade no Ordenamento Jurídico Brasileiro}

A Culpabilidade é o terceiro elemento do conceito analítico de crime. Ao analisar a culpabilidade, a atenção se volta para o agente e não mais para o fato. Isso porque a tipicidade e a ilicitude pertencem ao fato. A culpabilidade, por sua vez, ao agente.

Segundo o estudioso do assunto Santiago Mir Puig, a culpabilidade tem três funções. A primeira de ser elemento integrante do conceito analítico de crime: reprovabilidade ou reprochabilidade (censura), pois é um juízo de reprovação pessoal que recai sobre o agente que tenha praticado fato típico e ilícito. Essa reprovabilidade é jurídica e não social. A segunda de influenciar na dosimetria da pena (CP. art. 59). A terceira de afastar a responsabilidade objetiva, conforme o princípio da responsabilidade penal subjetiva. Dessa forma, um indivíduo não poderá ser responsabilizado sem que tenha agido com dolo ou culpa. ${ }^{130}$

\footnotetext{
${ }^{130}$ MIR PUIG, Santiago. Función de la pena y teoría del delito en el estado social y democrático de derecho. 2. ed. Barcelona: Bosch, 1982, p. 102-103.
} 
A culpabilidade, portanto, como conceito analítico de crime é um juízo de reprovação pessoal que recai sobre o agente imputável, que tinha potencial consciência da ilicitude quando praticou a conduta criminosa, sendo exigível dele uma conduta diversa da praticada ou uma conduta conforme o direito. Segundo Zafaronni, a culpabilidade pode ser resumida ao elemento da exigibilidade de conduta de diversa. Para o autor, a possibilidade de compreensão do injusto está na culpabilidade, não havendo relação com o dolo, quer este se localize no tipo ou na culpabilidade. O autor adota a teoria estrita da culpa. ${ }^{131}$

A teoria da culpabilidade teve três importantes fases na evolução histórica. A primeira foi a teoria psicológica da culpabilidade. A segunda, a teoria psicológica-normativa da culpabilidade e, a terceira, a teoria normativa.

Para a teoria psicológica, a culpabilidade se resumia a dados puramente psicológicos do agente. Consistia no vínculo psicológico estabelecido entre o agente e o delito por ele praticado, chamado de dolo e culpa. A culpabilidade ainda não tinha elementos, mas apenas dados psicológicos que consistiam na própria culpabilidade. $\mathrm{O}$ dolo e a culpa não estavam na conduta, mas sim na culpabilidade. Ao mesmo tempo vigorava na conduta a teoria causalista da ação.

Com a da teoria psicológico- normativa, a culpabilidade ganhou os elementos normativos da imputabilidade, potencial consciência da ilicitude e a exigibilidade de conduta conforme o direito; mas manteve os dados psicológicos (dolo e culpa) que estavam juntos da potencial consciência da ilicitude. A conduta não era dolosa e nem culposa, uma vez que o dolo e a culpa estavam dentro da culpabilidade. Ao mesmo tempo vigorava, na conduta, a teoria causalista.

\footnotetext{
${ }^{131}$ ZAFFARONI, Eugenio Raul. Manual de Direito Penal Brasileiro: volume 1 : parte geral In Eugenio Raul Zaffaroni, José Henrique Pierangeli- 9. Ed. Ver. e atual. - São Paulo : Editora Revista dos Tribunais 2011. p.535.
} 
Atualmente vigora em nosso ordenamento jurídico a teoria normativa pura de Hans Welzel. ${ }^{132} \mathrm{O}$ dolo e a culpa estão presentes na conduta. Quando deslocados da culpabilidade, o dolo levou consigo os dois elementos (vontade e consciência). A culpabilidade permaneceu com os elementos puramente normativos e os elementos psicológicos passaram a compor a conduta. Simultaneamente, passou a vigorar a teoria finalista da conduta.

A consciência do dolo é total, real, plena e efetiva sobre a conduta que se está praticando. A outra é a consciência da ilicitude, relação de contrariedade à norma penal, de que a conduta praticada é ilícita.

A imputabilidade, assim como a potencial consciência da ilicitude e a exigibilidade de conduta diversa são elementos da culpabilidade. No Brasil, são inimputáveis, pelo critério biológico, os menores de 18 anos (CF, art. 228). Considerando o fato da inimputabilidade biológica de 18 anos ser um direito individual do adolescente; o rol do artigo $5^{\circ}$ da Constituição Federal (CF art. $\left.5^{\circ} 2^{\circ}\right)$ não ser exaustivo e os direitos e garantias fundamentais não serem passíveis de emenda $\left(\mathrm{CF}\right.$, art. $60 \S^{\circ}$, IV, $\mathrm{CF})$; trata-se de cláusula pétrea. Dessa forma, é inconstitucional qualquer emenda que busque abolir o referido direito. Respeitado posicionamento contrário, conforme o do ilustre doutrinador Guilherme Nucci, que não considera o dispositivo cláusula pétrea, mesmo se posicionando contrário a diminuição da maioridade penal.

O procedimento adotado ao inimputável biológico se difere daquele dispensado ao imputável. O adolescente, quando suspeito da autoria de um ato infracional, é apreendido e encaminhado à delegacia especializada, chamada DPCA, caso não exista delegacia especializada será encaminhado a comum. Lavra-se o AIAI (auto de infração por ato infracional). Imediatamente o adolescente é apresentado ao membro do Ministério Público. O Ministério Público realiza a oitiva do adolescente e dos

${ }^{132}$ ZAFFARONI, Eugenio Raul. Manual de Direito Penal Brasileiro. Op.cit. p..524 
responsáveis e reduz a termo. Terminada essa fase, o Ministério Público poderá oferecer a representação contra o adolescente e, ao final da representação, pedir a aplicação de uma medida socioeducativa. O juiz recebendo a representação inicia a fase judicial e o adolescente será ouvido sobre o crivo do contraditório. Não sendo esse o caso, o Parquet poderá entregar o adolescente aos responsáveis, com o crivo do juiz. Poderá, também, requerer o arquivamento e decidir não representar em face do adolescente. Poderá, ainda, propor, ao juiz, a remissão do adolescente. Caso o juiz discorde do pedido do Ministério Público, remeterá os autos ao Procurador Geral (ECA, art. $\left.180 \S 2^{\circ}\right)$.

Quando o agente é imputável, tem potencial consciência da ilicitude e lhe é exigível a realização de conduta diversa da praticada, surge o conflito entre dois fundamentos da culpabilidade, o livre arbítrio e o determinismo. Segundo o livre arbítrio, o agente ao cometer um crime merece ser reprovado, pois agiu de forma livre. Não foi influenciado por qualquer fator exógeno ao praticar ato contrário ao direito. Por outro lado, segundo o determinismo, o agente ao cometer um crime sofre influências de fatores externos (cultura, princípios, modo de vida, exemplos). No Brasil é adotada a teoria do livre arbítrio.

Essa amplitude do âmbito de autodeterminação é essencial para o estudo da coculpabilidade, pois o Estado e a sociedade não podem se eximir de suas responsabilidades e sobrecarregar o indivíduo na aplicação da pena. ${ }^{133}$ Importante salientar que a coculpabilidade deve ser aplicada na segunda fase da dosimetria da pena, como atenuante genérica (CP art. 66).

A coculpabilidade, conforme defendido por Zaffaroni, Alejandro Alagia e Alejandro Slokar é o reconhecimento de que a sociedade não garante a todos os indivíduos as mesmas oportunidades, devendo o direito

${ }^{133}$ ZAFFARONI, Eugenio Raul. Manual de Direito Penal Brasileiro. Op.cit. p. 521. 
penal, na sua reprovação, adequar-se, em cada caso, ao espaço social conferido ao sujeito. ${ }^{134}$ Nesse sentido, leciona Miguel Reale:

O grupo social em que se encontra a criança e o jovem, os seus companheiros de brincadeira e de divertimento, os moradores da rua e do bairro em que reside, com todas as suas circunstâncias, pode constituir um ambiente que facilite ou dificulte o processo de socialização, conduzindo à conformidade ou à não conformidade com os valores morais consagrados pela sociedade. ${ }^{135}$

Isso é pertinente em razão do crime ser um fato social, antes de assumir efeitos jurídicos. O ser humano não é completamente livre para fazer suas escolhas, pois está inserido numa rede de significados. Numa sociedade desigual, cujas as oportunidades não são acessíveis a todos, torna-se necessário o reconhecimento dessas variáveis.

Dessa forma, não pode a sociedade e o Estado se esquivarem da parcela de culpa resultante do seu inadimplemento. A postura comissiva ou omissiva do Estado e da sociedade influenciam na posição de determinados indivíduos em situação diversa, sem oportunidades, por vezes, desconhecedores de outras expectativas. Nesse sentido, cumpre destacar os ensinamentos de Zaffaroni e Pirangeli:

Todo sujeito age numa circunstância determinada e com um âmbito de autodeterminação também determinado. Em sua própria personalidade há uma contribuição para esse âmbito de autodeterminação, posto que a sociedade - por melhor organizada que seja - nunca tem a possibilidade de brindar a todos os homens com as mesmas oportunidades. ${ }^{136}$

No Brasil, um caso emblemático de aplicação do princípio foi o do Marcos Paulo. O magistrado responsável pelo caso era Geraldo Mascarenhas do Prado. Tratava-se de crime de roubo, mediante violência ou grave ameaça, com uso de arma e em concurso de pessoas. O réu Marcos Paulo foi condenado. Entretanto, o Juiz ao verificar o seu passado de muita dificuldade econômica e seu contínuo envolvimento em pequenos

\footnotetext{
134 ZAFFARONI, Eugenio Raúl; ALAGIA, Alejandro; SLOKAR, Alejandro. Derecho penal: parte general, 2. ed. Buenos Aires: Ediar, 2002, p. 656.

${ }^{135}$ REALE JÚNIOR, Miguel, 1944- Instituições de direito penal-Rio de Janeiro: Forense, 2004. P.7

${ }^{136}$ ZAFFARONi, Eugenio Raul. Manual de Direito Penal Brasileiro: volume 1 : parte geral In Eugenio Raul Zaffaroni, José Henrique Pierangeli- 9. Ed. Ver. E atual. - São Paulo : Editora Revista dos Tribunais 2011. p.526.
} 
crimes, sem que o Estado tivesse tomado a medida socioeducativa cabível, quando adolescente, reconheceu a coculpabilidade. ${ }^{137}$

Entretanto, a jurisprudência ainda é tímida na aplicação do princípio, alegando a falta de previsão legal e a impossibilidade de culpar a sociedade e o Estado pelas escolhas individuais. ${ }^{138}$ O STJ não vem admitindo a tese

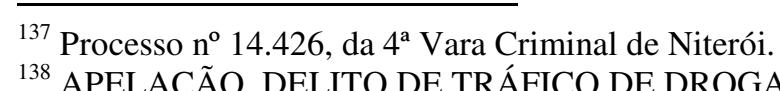
${ }^{138}$ APELAÇÃO. DELITO DE TRÁFICO DE DROGAS. DEFESA QUE SE INSURGE CONTRA A CONDENAÇÃO DO ACUSADO E REQUER, SUBSIDIARIAMENTE, A DESCLASSIFICAÇÃO DA CONDUTA IMPUTADA PARA A QUE TIPIFICA O DELITO DE CONSUMO PESSOAL DE ENTORPECENTES, A FIXAÇÃO DA PENA-BASE NO MÍNIMO LEGAL, A APLICAÇÃO DA ATENUANTE GENÉRICA PREVISTA NO ARTIGO 66 DO CÓDIGO PENAL, O RECONHECIMENTO DA CAUSA DE DIMINUIÇÃO INSERTA NO ARTIGO 33, § $4^{\circ}$, DA LEI N ${ }^{\circ} 11.343 / 06$, A SUBSTITUIÇÃO DA PENA PRIVATIVA DE LIBERDADE PELA RESTRITIVA DE DIRETOS E O ABRANDAMENTO DO REGIME PRISIONAL. PREQUESTIONAMENTO DE TODA A MATÉRIA IMPUGNADA. Dos pedidos de absolvição e desclassificação: a materialidade e a autoria delitivas foram absolutamente comprovadas na hipótese dos autos, notadamente pelos depoimentos prestados em Juízo, aos quais corroboram as demais provas do processo $i$ auto de prisão em flagrante e apreensão de adolescente, termos de declaração, laudo prévio de exame de entorpecente, auto de apreensão, autos de encaminhamento e laudo definitivo de exame de entorpecente, que não deixam a menor dúvida acerca da procedência da acusação. Com o fim da instrução criminal, restou incontroverso que o apelante trazia consigo e guardava, numa localidade onde se constitui um notório ponto de venda de drogas, $10,5 \mathrm{~g}$ de crack, sob a forma de 33 pedras, bem como 3,9g de maconha, além de 06 celulares, $\mathrm{R} \$ 357,00$ em espécie e diversos petrechos ligados ao tráfico de entorpecentes, o que evidencia a destinação das drogas apreendidas à mercancia ilícita. Da atenuante genérica: incabível o reconhecimento da atenuante prevista no artigo 66 do Código Penal, sob o flagrante disfarce da teoria da coculpabilidade, defendida pelo professor Eugenio Raúl Zaffaroni. Na hipótese vertente, não há uma prova concreta de que o acusado tenha uma baixa capacidade de autodeterminação, seja por influência de sua condição social ou não. Ao alegar a aludida tese, a defesa chamou para si o interesse de produzir a prova, mas assim não o fez, pois a versão apresentada carece, em regra, de exame pericial. Não obstante a responsabilidade parcial do Estado na formação do cidadão, as desigualdades sociais, próprias dos sistemas capitalistas, não podem servir como estímulo, tampouco como prémio, aos indivíduos que preferem se enveredar para a vida criminosa a buscar um trabalho lícito na sociedade. Da causa de diminuição: as circunstâncias da prisão em flagrante do réu, aliadas à forma de acondicionamento e à natureza devastadora do crack apreendido, evidenciam a dedicação à atividade criminosa. O local onde se deram os fatos constitui-se um notório ponto de vendas de drogas, razão pela qual a Polícia Militar fazia uma incursão na localidade quando da prisão do acusado, cuja dedicação ao tráfico é corroborada, inclusive, pelos petrechos destinados à mercancia ilícita de entorpecentes, apreendidos na residência do próprio apelante. Como se não bastasse, levando-se em conta a própria condenação do réu nos autos do processo $n^{\circ}$ 0002825-73.2007.8.19.0063, cuja sentença transitou em julgado em data anterior à prática do delito ora imputado, a concessão da minorante se mostra impossível. Da dosimetria da pena: a sanção penal se mostrou necessária à reprovação e prevenção do fato delituoso, mas mereceu alguns reparos, em observância aos princípios da razoabilidade e da proporcionalidade. Da substituição da pena privativa de liberdade: diante do quantum de pena a que restou condenado o acusado, a substituição pretendida pela defesa torna-se inexequível. Do regime prisional: a pena deverá ser cumprida em regime inicial fechado, a teor do artigo $33, \S \S 2^{\circ}$, b, e $3^{\circ}$, do Código Penal. Do prequestionamento: as questões expendidas para efeito do prequestionamento devem ser efetivamente discutidas, cabendo à defesa, além de indicar os dispositivos apontados para tal fim, motivar sua irresignação, não bastando a simples alusão a toda a matéria impugnada. Dessarte, ante o descumprimento do requisito da impugnação específica, rejeita-se o prequestionamento. RECURSO A QUE SE DÁ PARCIAL PROVIMENTO, a fim de reduzir-se a sanção penal definitiva para 06 anos de reclusão e pagamento de 600 dias-multa, à razão mínima legal, na forma inframencionada. Mantidos os demais termos da sentença. 
suscitada ${ }^{139}$. Contudo, o conceito encontra total respaldo nos princípios do Estado democrático de direito. Ao contrário do entendimento de alguns desembargadores do Tribunal de Justiça do Estado do Rio de Janeiro, tratase de medida de justiça e não de premiação pelo ato contrário ao direito. Nesse sentido, leciona o professor Rogério Grecco:

A teoria da coculpabilidade ingressa no mundo do Direito Penal para apontar e evidenciar a parcela de responsabilidade que deve ser atribuída à sociedade quando da prática de determinadas infrações penais pelos seus supostos cidadãos. Contamos com uma legião de miseráveis que não possuem teto para abrigar-se, morando embaixo de viadutos ou dormindo em praças ou calçadas, que não conseguem emprego, pois o Estado não os preparou e os qualificou para que pudessem trabalhar, que vivem a mendigar por um prato de comida, que fazem uso da bebida alcoólica para fugir à realidade que lhes é impingida, quando tais pessoas praticam crimes, devemos apurar e dividir essa responsabilidade com a sociedade. $^{140}$

Observado o ponto acima exposto, cumpre analisar a aplicação análoga do conceito de coculpabilidade às medidas socioeducativas. Em primeira análise, a aplicação do princípio apresenta uma questão técnica relevante, pois o adolescente em conflito com a lei não é culpável. Assim sendo, de acordo com a teoria analítica do crime, não comete crime. Por não existir culpabilidade, tampouco crime, não haveria de se falar em coculpabilidade.

Todavia, presentes os fundamentos materiais, não há qualquer impedimento para aplicação análoga do conceito. Nilo Batista defende que através da coculpabilidade, ao lado dos réus senta a sociedade que os

139 HABEAS CORPUS. TRÁFICO DE DROGAS. CONDENAÇÃO. APELAÇÃO JULGADA.PRETENSÕES DE ABSOLVIÇÃO E DESCLASSIFICAÇÃO. VIA INADEQUADA. EXAMEAPROFUNDADO DAS PROVAS. TEORIA DA COCULPABILIDADE DO ESTADO. NÃOCONFIGURAÇÃO. ORDEM DENEGADA. 1. Hipótese em que as instâncias originárias examinaram, comprofundidade, os elementos de convicção produzidos nos autos da açãopenal, concluindo pela condenação do paciente. Inviável atender apretensão defensiva, de absolvição ou desclassificação da conduta,nesta via estreita do mandamus, em que vedado o revolvimentofático-probatório. 2. O Superior Tribunal de Justiça não tem admitido a aplicação dateoria da co-culpabilidade do Estado como justificativa para aprática de delitos. Ademais, conforme ressaltou a Corte estadual,sequer restou demonstrado ter sido o paciente prejudicado por suascondições sociais. 3. Habeas corpus denegado.

(STJ - HC: 187132 MG 2010/0185087-8, Relator: Ministra MARIA THEREZA DE ASSIS MOURA, Data de Julgamento: 05/02/2013, T6 - SEXTA TURMA, Data de Publicação: DJe $18 / 02 / 2013)$

${ }^{140}$ GRECO, Rogério. Curso de Direito Penal: parte geral. 2. ed. Rio de Janeiro: Impetus, 2002. p. 469. 
produziu. ${ }^{141}$ Mais razão assiste, sentar a comunidade com o adolescente, na aplicação da medida socioeducativa, pois expressamente a Constituição Federal determinou o dever do Estado e da sociedade no zelo pelos direitos da infância, observado que um adolescente em conflito com a lei, quase sempre, é um indivíduo que anteriormente foi privado de seus direitos, a sociedade é coculpada pelo seu ato infracional . Dessa forma, não cabe o mesmo grau de reprovabilidade aos adolescentes com histórico de violações de direitos, daqueles que mesmo gozando de todo um aparato social escolhem praticar conduta diversa do direito. Nesse sentido, leciona Zaffaroni:

Reprovar com a mesma intensidade as pessoas que ocupam situações de privilégio e a outras que se acham em situação de extrema pecúnia é uma clara violação ao princípio da igualdade corretamente entendido. ${ }^{142}$

Uma das maiores justificativas para a aplicação análoga do princípio da coculpabilidade é a natureza jurídica da medida socioeducativa. Conforme entendimento do $\operatorname{STJ}^{143}$ e da doutrina moderna, além de pedagógica, é repressiva e retributiva, sendo as últimas características similares as da pena. Nessa seara leciona Marina de Aguiar Michelman:

Já se demonstrou ao longo deste artigo ser errônea a concepção de medida socioeducativa como resposta estatal pedagógica e não punitiva. De acordo com a mais moderna doutrina, as medidas socioeducativas são, tanto quanto as sanções penais, mecanismos de defesa social. Embora distingam-se da penas pela preponderância do caráter pedagógico sobre o punitivo, não deixam de lado o propósito intimidativo e expiatório próprio da pena, eis que autorizam a

${ }^{141}$ BATISTA, Nilo. Introdução crítica ao direito penal brasileiro. 8. ed. Rio de Janeiro: Revan, p. 105. Op. cit., p. 219

${ }^{142}$ ZAFFARONI, Eugenio Raul. Sistemas penales...-informe final, cit.,p. 58; cf. também política criminal latino-americana, cit.,p. 161 ss.

143 AGRAVO REGIMENTAL NO AGRAVO DE INSTRUMENTO. PENAL. ESTATUTO DACRIANÇA E DO ADOLESCENTE. PRESCRIÇÃO. PROVIMENTO. 1. "1. As medidas sócio-educativas, induvidosamente protetivas, sãotambém de natureza retributiva e repressiva, como na boa doutrina, não havendo razão para excluí-las do campo da prescrição, atéporque, em sede de reeducação, a imersão do fato infracional notempo reduz a um nada a tardia resposta estatal. 2. O instituto da prescrição responde aos anseios de segurança,sendo induvidosamente cabível relativamente a medidas impostascoercitivamente pelo Estado, enquanto importam em restrições à liberdade. 3. Tendo caráter também retributivo e repressivo, não há porque aviventar a resposta do Estado que ficou defasada no tempo. Tem-se,pois, que o instituto da prescrição penal é perfeitamente aplicávelaos atos infracionais praticados por menores." (REsp 171.080/MS, daminha Relatoria, in DJ 15/4/2002).2. Agravo regimental provido.

(STJ, Relator: Ministro HAMILTON CARVALHIDO, Data de Julgamento: 26/05/2004, T6 SEXTA TURMA) 
ingerência do Estado na liberdade individual do adolescente para lhe impor, coercitivamente, em programa pedagógico, seja em mediante privação de liberdade, seja pela iminência de reversão da medida em meio plena ou parcialmente aberto para internação-sanção, na forma do artigo 122, inciso III do ECA. ${ }^{144}$

Dessa forma, qualquer esforço em sentido contrário é conceder tratamento mais benéfico ao adulto. $\mathrm{O}$ adolescente não poder sofrer medida mais severa que o imputável, tal preceito é decorrente dos princípios da proteção integral (CF, art. 227) e da legalidade (CF, art. 50, inciso XXXIX). Essa previsão está expressa na Lei do SINASE ( Lei n. ${ }^{\circ}$ 12.594/12, art. 35, I) e no item 54 das Regras Mínimas das Nações Unidas para Prevenção da Delinquência Juvenil (RIAD). Nesse sentido, em 2014, decidiu o STF no habeas corpus a favor do adolescente que cumpria medida socioeducativa de internação por ato infracional análogo ao previsto no art. 28 da Lei 11.343/06. Segundo a decisão, o adolescente não poderia sofrer a medida de internação, pois nem mesmo a pessoa maior de 18 anos, imputável, poderia sofrer a privação de liberdade pela posse de drogas para consumo próprio. ${ }^{145}$

Não obstante, o Estatuto da Criança e do Adolescente prevê que o adolescente em conflito com a lei poderá sofrer as medidas socioeducativas de internação, semiliberdade, liberdade assistida, prestação de serviços à comunidade, obrigação de reparar danos ou advertência (ECA, art. 112), sem prejuízo de outras medidas (ECA, art. 101, I a VI).

Ao estabelecer essas medidas, a legislação perdeu uma grande oportunidade de se desvincular das penas previstas na execução penal, observado que a internação, a semiliberdade e a liberdade assistida guardam profundas semelhanças com as previstas no sistema penal. Não obstante, muros altos, uniformes, o reconhecimento dos adolescentes por número, são algumas questões que contradizem com a natureza pedagógica da medida mostrando muito mais proximidade com a legislação punitiva dos adultos que com a protetiva da infância.

\footnotetext{
${ }^{144}$ MICHELMAN, Marina de Aguiar,. em artigo publicado na "Revista Brasileira de Ciências Criminais" n. 27, de julho-setembro de 1999, p. 212-213.

${ }^{145}$ Relator: Ministro Celso de Mello, HABEAS CORPUS 124.682 SÃO PAULO.
} 


\subsection{Aplicação Análoga do Princípio da Coculpabilidade às Medidas Socioeducativas à Luz dos Casos Concretos e a Substituição da Justiça Punitiva pela Justiça Restaurativa}

A instituição de acolhimento e a unidade de cumprimento de medida socioeducativa são espécies de instituições totais. No Rio de Janeiro, os aspectos que unem ambas as instituições são maiores que os traços que as distinguem. Desde o perfil arquitetônico, aos padrões de comportamento, é possível observar a linha tênue que separa as duas medidas, a protetiva da socioeducativa.

Apontando as semelhanças entre as medidas supracitadas e as violações de direitos presentes nas instituições de acolhimento, esse subcapítulo se inicia com o depoimento de Mateus. Mateus entrou na sala um pouco assustado. Provavelmente porque não costuma ser chamado, tampouco, para boas notícias ou uma simples conversa. O histórico de sofrimento refletia em seus olhos assustados, cicatrizes e corpo franzino. Após explicar a finalidade do trabalho e pedir permissão para gravar, Mateus começa a contar sua história explicando o motivo pelo qual está na internação provisória no Dom Bosco.

“ M: tenho 4 passagens, a primeira vez que eu vim pra cá eu rodei com um canivete grandão lá no ônibus. Não era roubando não. Era para se defender na rua. Já me ajuntaram 3 vezes ali na Central. Maluco de outra facção. Aí vou lá almoçar no garotinho todo dia. Aí fui lá almoçar, aí levei meu canivete dessa vez. Aí fui sair entrando correndo ônibus aí o canivete acabou caindo do meu bolso. Aí tinha algumas pessoas que se assustou chamando a polícia e aquilo que eu queria roubar e não sei o que...Mas aí a mulher que foi até a delegacia disse que eu não cheguei a encostar em ninguém que ela só viu o canivete caindo no chão. Uma passagem foi no canivete, a outra foi no 155 , lá no posto 8 , a outra foi no 157, ali no posto 5, aí a outra foi no 155 de novo ali na Americana, em Copacabana mesmo. Minha família é da rua. Minha mãe e minha irmã é da rua. A gente fica em Copacabana "PPG", Pavão Pavãozinho."146

Em primeira análise, Mateus está aguardando audiência por um furto. No Estado do Rio de Janeiro é comum a violação ao devido processo legal. O furto não envolve violência ou grave ameaça, sendo inaplicável a

\footnotetext{
${ }^{146}$ Entrevista realizada no Dom Bosco no dia 03/05/2015.
} 
medida socioeducativa de internação. Dessa forma, fazer o adolescente aguardar provisoriamente internado por uma sentença que não comporta medida de internação revela uma forma de castigo. Nesse sentido, uma adolescente da unidade Santos Dumont, que também aguardava a audiência internada, por primeira passagem em ato infracional análogo ao tráfico, revelou que estava ali, segundo o promotor, só de "castigo", pois não seria aplicada a internação.

Retornando a entrevista, quando interrogado se havia passado pelas instituições de acolhimento, Mateus perde parte da tranquilidade, começa a gesticular mais e seu tom de voz aumenta consideravelmente. $\mathrm{O}$ adolescente revela a forma violenta como são transportadas as pessoas para essas instituiçõos. Transparece, ainda, a sua revolta pelo choque de ordem ter lhe tirado todos os documentos. Isso é muito problemático, pois vários adolescentes, em situação de rua, estão sem documentos, facilitando a arbitrariedade do Estado.

E: Passou por instituições de acolhimento?

M: Muito, muito, muito...milhão de vez. Tem uns cara que vinham de van e sai enfiando a porrada em nós, batendo, chutando a cara, dando muito soco na cara. Jogaram a gente para dentro da van obrigando a gente a ir."

E: Quantos anos você tinha quando passou pelo abrigo pela primeira vez?

M: Tinha uns 5 ano. Tiraram meus documentos todos. Com esse negócio de choque de ordem sumiram com nossos documentos todo. Agora minha mãe não tem documento nenhum nem da minha irmã. Não tenho nenhum documento nem eu nem minha irmã. Levaram nossas coisa. Sumiram com nossos documento todo.

E: A sua irmã tem quantos anos?

M: “Tem 14."147

Quando interrogado sobre as instituições pelas quais passou, o adolescente conta toda sua história de alternância entre a rua e o abrigo.

E: Quais foram os abrigos que você passou?

M: Passei pela Carioca, Amar...

E: Qual lembrança você tem desses abrigos?

M: Último foi de lá de Nova Iguaçu.

E: Como foi parar em Nova Iguaçu se sua família é daqui?

M: Porque nasci na Central, aí fiquei uns tempo aqui, aí pouquinho maiorzinho minha mãe foi para Nova Iguaçu.

E: Mas tinha parente, alguém lá?

${ }^{147}$ Entrevista realizada no Dom Bosco no dia 03/05/2015. 
M: “Não...Sempre moramo na rua."

M: Já morei no Morro Agudo, Nova Iguaçu, já ficamo em Marechal, que já estudei em Marechal, atrás da Gruta, CIEP Augusto Pereira de Carvalho, o nome do colégio. Aí minha mãe já foi para Madureira. Depois para Cascadura. Campo Grande, essas coisa. Aí agora veio para cá para o Rio, para Copa. Ah! Falar a verdade, a gente já teve uma casa sim no menino de Deus em São Gonçalo. Aí a gente viemo para cá de novo.

E: Porque saíram de lá?

M: " Não era uma casa. Era tipo um salão de festa, grandão assim. Era esse cômodo aqui com outro igual esse assim, grandão. A gente tava morando lá. Era de uma mulher. Tipo lá no topo . Lá no escadão. A gente morava ali assim. Aí a mulher falou para a gente ficar uns tempo lá até a gente conseguir uma moradia por lá. Aí a gente não conseguiu. Aí minha mãe foi, saiu no carnaval. Aí nem tinha percebido que minha mãe tinha saído aí fiquei dormindo na rua sozinho para não dormir em casa sozinho. Aí quando subimo p lá já tinham roubado várias coisa lá dentro. Que aí minha mãe ensinou o número do cadeado dela $\mathrm{p}$ gente estranho. Aí mexeram nas coisa dela. Um monte de coisa ela perdeu. Lá no morro mesmo venderam as coisa dela. ${ }^{148}$

Mateus revela uma questão interessante no depoimento acima, o medo de ficar na "casa" sozinho. O adolescente se sentiu mais seguro dormindo na rua. Ao longo do depoimento ele retorna com a questão de sentir maior segurança na rua. A seguir, o menino comenta o baixo grau de escolaridade.

E: Está com quantos anos?

M: 17 anos.

E: Série?

M: Parei na primeira. Não sei ler não. Só sei escrever meu primeiro nome. ${ }^{149}$

Nesse momento, o adolescente começa a falar sobre as questões internas das instituições de acolhimento, descrevendo a Central Carioca. Ele reforça a questão da violência no transporte para esses lugares.
E: Como você era tratado no abrigo?
M: Nova Iguaçu só fui uma vez só. Tudo p2. Fui pego em Nova Iguaçu. Estava sentado na pastelaria. Era tudo p2. O cara me segurou e ainda deu um lanche. Aí chegou a kombi, nessa época eles trabalhava de kombi, agora é essas van aí que esses cara usam.
E: Como é o contato?
M: Eles bate. Se eu tiver andando e eles reconhecer. Aí eles vem. Tem uns que corre atrás pra caramba. Aí você corre parece que está devendo e tudo. Aí antes de jogar na van tem que passar pela delegacia para ver se o menor está devendo.
E: A diferença do abrigo para o Padre?
M: Aqui é um pouco pior.
E: Qual a diferença? O que te incomodava no abrigo?

\footnotetext{
${ }^{148}$ Entrevista realizada no Dom Bosco no dia 03/05/2015.

${ }^{149}$ Entrevista realizada no Dom Bosco no dia 03/05/2015.
} 
M: Os educador deixava os outro brigar lá, fazer mano a mano com o outro, um fica betendo no outro toda hora. Escondeu a chinela e os educador não fala nada. Aí só porque um menino brigou com o outro, os educador pega leva para uma salinha tem uns cara que bate para caramba.

E: Isso em qual?

M: Na Central Carioca.

E: Quem bate "pra caramba" os adolescentes ou os educadores?

M: Os educador e os adolescente também. Aí tem os adolescentes que fecha com os educador. Apanha e bate também. ${ }^{150}$

O adolescente mostrando grande preocupação com sua irmã se esquiva da pergunta sobre a mãe e começa a contar a história dela. Mateus revela a prática de violência sexual, tanto nas instituições de acolhimento como nas unidades de medida socioeducativa, por parte dos próprios internos.

E: Como é seu contato com sua mãe?

M: Vou falar da minha irmã. Tem um abrigo de menina Taiguara ali que é ali na lapa. Ela vai para ali que só pode entrar bebelzinho que tem 12 ano pra baixo. Duvido nada que lá ele faz umas safadeza também. Lá as garota faz safadeza com a outra. Uma fica dedando a outra.

E: Algum tipo de violência? Elas querem ou obrigam?

M: Umas que quer e outras que não quer. Minha irmã passou porque quis. Porque lá tem meninas que querem com a outra.

E: No masculino?

M: Já vi muitos, tipo aqui no CTR. Que o moleque estrupo um bebelzinho. Colocou ele para tocar, desculpa, e depois segurou as perna, o outro os braço e tentou estrupar o garoto.

E: O que você acha do abrigo?

M: É muito ruim. Desde pequeninho que falo abrigo não é bom. Não é bom, mas aí vou mesmo por causa da minha mãe que fica na rua. Às vezes é difícil em tempo de frio de chuva.

E: E sua mãe?

M: Minha mãe incentiva eu e minha irmã ir pra o abrigo, mas ela fica muito triste e sofre muito.

Aqui tinha um abrigo de família, aqui mesmo, atrás do Padre. Levava as pessoas que eles pegava lá. Minha mãe já veio para cá. Pegaram nós na força. Uma mulher que conhecia nós chamou nós tranquilo $\mathrm{p}$ nós vir. Aí nós tava com 2 carrinhos de mercado de roupa, com uma cachorra nossa que teve filhote. Aí foram pegaram os filhote colocaram tudo dentro da van. Aí pegaram nossa cachorra colocaram dentro da van também. ${ }^{151}$

Quando interrogado se preferia a rua ou o abrigo, o adolescente fala mais detalhes sobre as práticas de violência dentro da Central Carioca, revelando, ainda, o esquema para tentar esconder as verdadeiras condições institucionais da fiscalização.

${ }^{150}$ Entrevista realizada no Dom Bosco no dia 03/05/2015.
${ }^{151}$ Entrevista realizada no Dom Bosco no dia 03/05/2015. 
E: Prefere a rua ou o abrigo? Porque?

M: A rua. Abrigo a gente come na moral, mas não tem a paz que tem na rua. A gente é muito oprimido pelos moleque e pelos educador. É muita oprimição. Às vezes você faz um negocinho de nada. É errado é errado, mas foi sem querer, os cara não pensa duas vezes, coloca de cabeça pra parede aí tu fica sozinho trancado num bagulho, Deus me livre.

E: Que tipo de coisa errada?

Tipo, o tio falou pra tu não ligar a televisão aí tu vai lá e liga. Tem umas pessoa que não sabe, porque ele não fala também, aí você vai liga a televisão. Aí eles pega bate, faz o que quiser, porque eles são educadores.

E: Alguém fiscalizou?

M: Repórter, juiz, promotor, defensor, mais repórter, mas não melhora em nada. De um dia pra outro eles sabe que as pessoas vai lá. Aí eles melhoram tudo, arrumam tudo, dá até negócio pra as crianças falar que não sei o que tá bom. Dão coisa de comer às vezes. Tipo comprando nós. Tem umas coordenadorazinha que é chata e fala para os cara pisar no nosso pé. Pisar no pé é os cara vir bater em nós. Não vou passar a mão na cabeça não.

E: De qual abrigo você está falando?

M: Carioca. Tinha um moleque lá que vinha pra bater. Já cheguei a sonhar de olho aberto.

E: Você é usuário?

M: Já fui usuário de tinder. Crack já usei. ${ }^{152}$

Esse foi um dos momentos mais complicados da entrevista. O adolescente teve muita dificuldade para se projetar no futuro. Demorou muito para entender e responder a pergunta. A bateria do celular acabou sem que ele expusesse uma forma de realizar seu sonho. $\mathrm{Na}$ verdade, ele não respondeu à pergunta.

E: Como você se vê daqui uns anos?

M: Se tivesse usando crack morto.

E: Mas como você está agora, sem usar, como você se vê?

M: Minha vida vai mudar. Com certeza Deus vai dar uma casinha pra mim e minha irmã morar. Aí a gente vai sair dessa vida. ${ }^{153}$

Mediante o depoimento apresentado, complexo em toda sua narrativa, podem ser observadas algumas questões pertinentes aos indivíduos institucionalizados. Mateus fala que o Dom Bosco é apenas "um pouco pior" que as instituições de acolhimento pelas quais passou. Conforme relatou a assistente social, Lisiane Dias, essas pessoas estão adaptadas dentro de instituições totais, in verbis:

\footnotetext{
${ }^{152}$ Entrevista realizada no Dom Bosco no dia 03/05/2015.

153 Ibid.
} 
“ (...) Com essa questão da institucionalização a gente percebe que os meninos que vem de institucionalização quando a gente atende eles aqui, eles na verdade se sentem muito familiarizados com o local. Eles se sentem familiarizados com a rotina, eles se sentem familiarizados com a questão do controle sobre aquilo que eles fazem. O que a gente observa que incomoda muito os meninos que vem das suas casas, de um núcleo familiar, nos meninos que vem de institucionalização normalmente não. Geralmente eles estão muito familiarizados com essa rotina de ficar o tempo inteiro sob a vigilância de alguém, seguindo determinadas regras que não foram decididas e não tiveram participação deles. Então eles estão muito acostumados com esse contexto. E eles normalmente se comportam dentro na unidade com muita familiaridade em relação a isso. Logo que eu entrei aqui eu tive o caso de um menino que disse que achava que era muito bom ficar No Padre porque nos abrigos por onde ele tinha passado ele teve experiências muito ruins. Então ele achava que o Padre era ótimo. Ele dizia que aqui ele ficava bem, que ele preferia ficar aqui do que nos abrigos por onde ele tinha passado. De início choca um pouco, mas quando a gente pensa na lógica, a gente vai perceber que de fato a estrutura que ele conhece é essa. É a estrutura do controle. Então se ele conhece a estrutura do controle é essa estrutura que vai fazer ele se sentir à vontade. Então no geral é esse o perfil de menino que vem de institucionalização que se "acomoda" com muita facilidade a essa rotina e, dificilmente, pela correlação que a gente faz disso com a reincidência, ele consegue sair desse ciclo, porque ele acaba retornando para a rua e da rua ele acaba sendo acolhido de novo. Ele às vezes foge do acolhimento e torna a reincidir no ato infracional e volta para cá. Então ele está sempre nesse ciclo, quando ele não está na institucionalização fora daqui, ele está aqui. Então ele mantém o ciclo da institucionalização, seja na de acolhimento, por medida protetiva, ou, aqui, por medida socioeducativa. Ele está alternando entre uma e outra."154

Importante frisar, na narrativa do Mateus, a ausência de momentos felizes. Em momento algum, o adolescente relata uma experiência boa. Essa é a sua quarta passagem pelo sistema socioeducativo. Pelo ato infracional cometido, provavelmente, sofrerá uma medida de liberdade assistida. Entretanto, voltará a morar nas ruas ou no abrigo. Continuará sem frequentar a escola. Sua irmã, uma adolescente de apenas 14 anos, sofre o risco das piores formas de violência nas ruas, conforme confidenciou o adolescente, a mãe já a salvou de um estupro.

Destaca-se que, muito embora o ECA tenha consolidado os eixos de promoção, defesa e controle, os mesmos não funcionaram para o Mateus. Quando interroguei se já havia ouvido falar em aluguel social, a sua resposta foi não e perguntou o que seria isso. Importante salientar que o adolescente sabe o nome completo da escola onde estudou. Logo, esse foi um ambiente importante em sua vida.

${ }^{154}$ Ibid. 
Dessa forma, existe uma culpa do Estado e da sociedade pelos atos infracionais cometidos por Mateus. Mateus não tem escola, casa e comida. Foi apreendido tentando furtar nas lojas americanas. O adolescente confidenciou a preferência por esmolar em detrimento de "roubar", mas quando a fome apertava não havia outra opção.

Bruno, que também passou pela Central Carioca, relatou as condições e o problema dos funcionários da central de triagem. Contou que apenas ficou de um dia para o outro, pois evadiu. $\mathrm{O}$ adolescente morava com a mãe e mais nove irmãos num cortiço em Sacadura Cabral, quando foi apreendido. Atualmente a família mora em Belford Roxo. O adolescente não é um caso de institucionalização total, pois tem casa e família, no mais, a sua passagem pelo acolhimento institucional foi esporádico. Contudo, da sua narrativa são extraídas questões importantes levantadas pelo Mateus.

\footnotetext{
"Rodei fumando baseado aí eu fui. Aí me pagaram levaram pra delegacia porque minha mãe não foi me buscar porque minha mãe trabalhava. Aí fui transferido pra o abrigo. Aí cheguei lá não tinha sabonete. Só tinha uma mesa de ping-pong. Para ver televisão tinha que sentar no chão assim frio. A cama, deitava na cama, a cama começava a balançar muito."

" Na Central Carioca tinha só funcionário que era cheio de marra."
}

A adolescente Fernanda cumpre medida socioeducativa de internação na unidade Santos Dumont. A entrevista com a adolescente foi realizada sem gravador, pois havia a presença de uma amiga sua na sala. Dessa forma, foram anotadas as principais observações. A menina narrou o falecimento de sua mãe e que morava com o pai e a madrasta, mas em razão da morte do pai foi parar na instituição de acolhimento Ayrton Sena. Fernanda estava ansiosa com uma questão, a sua maior preocupação era a medida socioeducativa de semiliberdade. Ela disse se sentir muito angustiada, foi exatamente essa palavra, pois não havia quem a buscasse nos finais de semana. Pediu para ver resolver essa questão. ${ }^{156}$

A psicóloga Maura é responsável pela equipe técnica da unidade de internação Santos Dumont e conhece a Fernanda desde o período de

\footnotetext{
${ }^{155}$ Ibid.

${ }^{156}$ Ibid.
} 
acolhimento institucional. A mesma relatou que a adolescente, certa vez, relutou em entrar numa exposição no $\mathrm{CCBB}$, pois não tinha autoestima suficiente para conviver no mesmo espaço que as demais pessoas da sociedade. ${ }^{157}$ Tamanha sua identificação com as instituições, não mais se via como os outros. Essa questão é levantada por Goffman, no seu livro sobre as instituições totais, senão vejamos:

Para o internado, o sentido completo de estar "dentro" não existe independentemente do sentido específico que para ele ter o "sair" ou "ir para fora", Neste sentido, as instituições totais realmente não procuram urna vitória cultural. Criam e mantem um tipo específico de tensão entre o mundo doméstico e o mundo institucional, e usam essa tensão persistente como uma forca estratégica no controle de homens. ${ }^{158}$ (Goffman, p. 23-24.)

Observadas as entrevistas acima expostas, as medidas socioeducativas não são eficazes quando o adolescente em conflito com a lei vem de instituição de acolhimento, principalmente a de internação, pois afasta ainda mais da sociedade quem nunca esteve inserido. Para esse indivíduo o espaço fechado da instituição é familiar, pois está acostumado com seu funcionamento.

Dessa forma, é preciso voltar os olhos para uma nova forma de medida socioeducativa, através do direito restaurativo. Essa justiça, aliada aos eixos de prevenção, defesa e controle, determinados pelo ECA, poderão possibilitar a inserção desse adolescente no espaço social, desenvolvendo a empatia e a autoestima, uma vez que um dos alicerces da justiça restaurativa é a participação da comunidade.

Considerando o Estado e a sociedade coculpados pelos atos infracionais cometidos por esses indivíduos, uma vez que esses foram vítimas das piores formas de violações de direitos, dentro do ambiente institucional, a justiça restaurativa proporcionará o levantamento de todas essas questões.

\footnotetext{
157 Ibid.

${ }^{158}$ GOFFMAN, E. Manicômios, prisões e conventos. $2^{\mathrm{a}}$ ed. São Paulo: Perspectiva. 1987. pp. 2324.
} 
Nesse sentido, a sociedade, como convidada a participar desse processo de reflexão do ofensor, tem a oportunidade de refletir a sua culpa e contribuir na inclusão do adolescente na cultura social. Assim, haverá uma reconciliação entre a sociedade e o ofensor.

A justiça restaurativa rompe com o modelo retributivo e instaura o paradigma restaurador. De acordo com L. Walgrave, conforme o quadro abaixo, a justiça é marcada pelo direito penal, o reabilitador e o direito restaurativo: ${ }^{159}$

\begin{tabular}{|c|c|c|c|}
\hline & Direito Penal & $\begin{array}{l}\text { Direito } \\
\text { Reabilitador }\end{array}$ & $\begin{array}{l}\text { Direito } \\
\text { Restaurador }\end{array}$ \\
\hline $\begin{array}{l}\text { Ponto de } \\
\text { referência }\end{array}$ & O delito & $\begin{array}{l}\mathrm{O} \text { indivíduo } \\
\text { delinquente }\end{array}$ & $\begin{array}{l}\text { Os prejuízos } \\
\text { causados }\end{array}$ \\
\hline Meios & $\begin{array}{l}\text { A aflição de uma } \\
\text { dor }\end{array}$ & O tratamento & $\begin{array}{l}\text { A obrigação para } \\
\text { restaurar }\end{array}$ \\
\hline Objetivos & $\begin{array}{l}\text { O equilíbrio } \\
\text { moral }\end{array}$ & A adaptação & $\begin{array}{l}\text { A anulação dos } \\
\text { erros }\end{array}$ \\
\hline $\begin{array}{l}\text { Posição das } \\
\text { Vítimas }\end{array}$ & Secundário & Secundário & Central \\
\hline $\begin{array}{l}\text { Critérios de } \\
\text { Avaliação }\end{array}$ & $\begin{array}{l}\text { Uma "pena } \\
\text { adequada" }\end{array}$ & $\begin{array}{l}\mathrm{O} \text { indivíduo } \\
\text { adaptado }\end{array}$ & $\begin{array}{l}\text { Satisfação dos } \\
\text { interessados }\end{array}$ \\
\hline Contexto Social & $\begin{array}{l}\text { O estado } \\
\text { opressor }\end{array}$ & $\begin{array}{l}\text { O estado } \\
\text { providência }\end{array}$ & $\begin{array}{l}\text { O Estado } \\
\text { responsável }\end{array}$ \\
\hline
\end{tabular}

A justiça restaurativa foca, inicialmente, nas consequências causadas pelo ato infracional; enquanto a medida socioeducativa, no seu atual modelo, apoia-se no ato infracional e, a justiça reabilitadora, no adolescente delinquente. O direito restaurativo busca anular os erros através da reparação dos danos diretos e indiretos; a medida socioeducativa, com sua

\footnotetext{
${ }^{159}$ WALGRAVE, L., 1993. Au-delà de la rétribution et de la réhabilitation : la réparation comme paradigme dominant dans l'intervention judiciaire contre la délinquance des jeunes? in J. F. Gazeau e V. Peyre, eds., La justice réparatrice et les jeunes (Vaucresson, 9ièmes journée internationales de criminologie juvenile): pp. 5-28.
} 
natureza semelhante a do direito penal, visa restabelecer um equilíbrio moral causado por uma ação em desconformidade com o direito; a visão reabilitadora procura recuperar o transgressor através de um tratamento. Apenas através do direito restaurador a vítima assume uma posição central, pois nos outros dois modelos figura como secundário. Os critérios utilizados para avaliar o alcance dos objetivos atribuídos a cada tipo de direito são muito diferentes. O direito restaurativo vai buscar, ainda, a satisfação dos principais envolvidos no ato infracional, não se limitando a proporcionalidade penal, nem a readaptação do adolescente delinquente. ${ }^{160}$

A medida socioeducativa em sua natureza similar a do direito penal não surte os efeitos desejados de restaurar as consequências diretas e indiretas do ato infracional, tampouco, ressocializar os adolescentes. Isso porque nos casos apresentados no trabalho, esses indivíduos nunca estiveram inseridos no meio social. Portanto, o atual modelo de medida socioeducativa apenas contribui para seu reconhecimento na cultura fora da sociedade, ou seja, da instituição.

Não obstante, a evolução social está relacionada a abolição do direito penal. Quanto mais evoluída uma sociedade menos serão as práticas punitivas. A tentativa de resolver problemas sociais com política criminal sempre foi ineficaz. Nesse sentido, cabe citar Zaffaroni:

que nos permita explicar como operam os controles sociais punitivos de nossa margem periférica, que condutas e atitudes promovem, que efeitos provocam e como os encobre enquanto isso seja necessário ou útil para projetar alternativas para as soluções punitivas ou soluções punitivas alternativas menos violentas que as existentes e mais adequadas ao progresso social. ${ }^{161}$

A justiça restaurativa, por sua vez, apresenta-se como uma alternativa capaz de romper esse ciclo relatado pela assistente social de:

\footnotetext{
${ }^{160}$ WALGRAVE, L., 1993. Au-delà de la rétribution et de la réhabilitation : la réparation comme paradigme dominant dans l'intervention judiciaire contre la délinquance des jeunes? in J. F. Gazeau e V. Peyre, eds., La justice réparatrice et les jeunes (Vaucresson, 9ièmes journée internationales de criminologie juvenile): $\quad$ pp.

${ }^{161}$ ZAFFARONI, Eugenio Raul. Criminología: aproximación desde un margen. Bogotá: Temis, 1988. v. 1. p.20.
} 
Unidade de medida socioeducativa-instituição de acolhimento-rua-ato infracional- medida socioeducativa, conforme destaca Cormier:

\begin{abstract}
A justiça restaurativa é uma aproximação de justiça centrada na correção dos erros causados pelo crime, mantendo o infrator responsável pelos seus atos, dando diretamente às partes envolvidas por um crime - vitima(s), infrator e coletividade - a oportunidade de determinar suas respectivas necessidades e então responder em seguida pelo cometimento de um crime e de, juntos, encontrarem uma solução que permita a correção e a reintegração, que previna toda e qualquer posterior reincidência. ${ }^{162}$
\end{abstract}

Dessa forma, o ofendido poderá demonstrar as consequências diretas e indiretas do ato sofrido propondo, ao ofensor, um processo reflexivo; o ofensor terá a oportunidade de reconhecer as consequências intencionais do ato infracional, assim como os reflexos que muitas vezes extrapolam o campo das intenções.

Com esse propósito, a justiça restaurativa vai analisar todo o contexto social desse indivíduo, através da participação da comunidade do ofendido e do ofensor. A sociedade, também responsável pela situação do adolescente, é convidada a participar do processo de solução do conflito.

O procedimento ocorre através de entrevistas com a vítima e o ofensor, de forma voluntária, acompanhados dos advogados. Eles são esclarecidos sobre os objetivos do trabalho a ser realizado. Ocorre através da mediação penal, conferências familiares e círculos de construção de consenso. $^{163}$

A Mediação Penal é o processo pelo qual o ofendido e o ofensor participam ativamente da solução das consequências do conflito com o auxílio de um mediador.

As Conferências Familiares são utilizadas na orientação da família e da comunidade. Essa orientação funciona no sentido conduzir a família e a sociedade no suporte ao ofensor, tanto no cumprimento do acordado com a vítima, como em sua mudança de comportamento. Representantes do

\footnotetext{
162 apud JACCOUD, 2005, p. 169.

${ }^{163}$ Guia de procedimento Restaurativo implementado em porto Alegre e presente em JUSTIÇA PARA O SÉCULO 21: Instituindo Práticas Restaurativas: Manual de práticas Restaurativas/Compilação, sistematização e redação Leoberto Brancher, Tânia Benedetto Todeschini, Cláudia Machado. - Porto Alegre, RS: AJURIS, 2008, p.27.
} 
Estado podem estar presentes para equilibrar os interesses de vítima e do ofensor.

Os Círculos de Construção de Consenso, por sua vez, inspirados em comunidades indígenas, são baseados na conversa e na construção de consenso envolvendo um número maior de pessoas. Contam com a presença do juiz e a construção consensual da sentença para o delito. ${ }^{164}$

Entretanto, no Brasil é tímida a aplicação do direito restaurativo no âmbito penal. A Lei 9099/95 prevê nas situações em que vigora o princípio da oportunidade, ou seja, nos crimes de ação penal privada, cujo ajuizamento esteja inteiramente a critério do ofendido, as partes poderão optar pelo direito restaurativo.

No Rio de Janeiro, atualmente, está acontecendo a 1 Formação básica de derivadores de casos e potenciais agentes multiplicadores voltada para profissionais do Poder Judiciário, da Defensoria Pública, do Ministério Público, dos 67 CREAS, da Rede Nacional de Defesa de Adolescentes em conflito com a lei (RENADE), dos Centros de Defesa da Criança e do Adolescente, das Comissões Municipais e Estaduais de implementação do plano de atendimento socioeducativo e demais profissionais que atendem adolescentes em conflito com a lei. ${ }^{165}$

\footnotetext{
${ }^{164}$ Guia de procedimento Restaurativo implementado em porto Alegre e presente em JUSTIÇA PARA O SÉCULO 21: Instituindo Práticas Restaurativas: Manual de práticas Restaurativas/Compilação, sistematização e redação Leoberto Brancher, Tânia Benedetto Todeschini, Cláudia Machado. - Porto Alegre, RS: AJURIS, 2008, P.27.

${ }^{165} \mathrm{http}: / /$ www.cedecarj.org.br. Acesso em 17/06/2015.
} 


\section{CONSIDERAÇÕES FINAIS}

O Brasil tem um histórico complexo de institucionalização de crianças e adolescentes. O problema poderia ser parcialmente evitado com a implementação de políticas públicas voltadas para a família, uma vez que a extrema pobreza é um dos fatores incisivos nesse processo. A capacitação das funções judiciais também é problemática, pois a retirada de crianças da convivência familiar, muitas vezes, é realizada tendo como parâmetro a qualidade de vida da classe média. Em diversos casos concretos é necessária a retirada da criança e do adolescente da sua família natural, não sendo possível a colocação em família extensa ou substituta. Verifica-se, ainda, a criação de entraves pelo Judiciário, não previstos em lei, ao processo de adoção.

Dessa forma, é preciso um olhar crítico para a existência e a necessidade das instituições de acolhimento. Ela necessita sair do espaço de invisibilidade, pois o escondido é abandonado e no silêncio moram as piores formas de violações de direito. $\mathrm{O}$ acolhimento institucional pode trazer aspectos positivos ou negativos, dependendo da forma como ele é realizado. Então, a sociedade precisa trazer a instituição de acolhimento para as discussões, pois caso contrário apenas reforçará a exclusão. Como indivíduo e espaço são indissociáveis, consequentemente os sujeitos que se formaram nesses ambientes não se reconhecerão como integrantes da cultura social.

Levantar essa questão não significa desprezar o direito fundamental à convivência familiar. Pelo contrário, não são processos excludentes, mas complementares. Se por um lado deve ser investido na família natural, extensa, acolhimento familiar, ou, até mesmo na família substituta. Por outro lado, a instituição de acolhimento é a realidade de crianças e adolescentes que, por diversos motivos, por distintos períodos de tempo, não usufruem dessas opções. Considerando esse período fundamental na 
formação do indivíduo, mas ao mesmo tempo curto, é de extrema crueldade o excesso de discursos bonitos, ainda que bem-intencionados, responsáveis por intensificar o processo de marginalização.

Não obstante, a questão da exclusão e da criação de uma sociedade entre muros é apontada nas narrativas dos adolescentes e dos demais envolvidos no espaço institucional. Dessa forma, a criança e o adolescente institucionalizados acabam criando uma identidade a partir da ausência. São os indivíduos sem casa, sem família, sem história. Isso faz com que se sintam numa posição de inferioridade, quase antagônica, em relação aos indivíduos fora do ambiente institucional.

Diante desse cenário, algumas instituições de acolhimento acabam adotando uma postura violadora de direitos. $\mathrm{O}$ adolescente que cresce nesse ambiente de privação e violência tem seu livre arbítrio comprometido. Ao cometer um ato infracional, esse indivíduo tem uma medida socioeducativa de natureza pedagógica, retributiva e punitiva, características similares as da pena. Então, o sistema apresenta a contradição de manter institucionalizado, numa unidade de medida socioeducativa, com o objetivo de ser ressocializado, o sujeito que nunca chegou a ser integrado na sociedade. A ineficácia de tal medida é absoluta, pois esse adolescente conhece o espaço de institucionalização, ele desconhece o espaço social. Dessa forma, as medidas socioeducativas, da forma como vem sendo adotadas, apenas reforçam a exclusão e a reincidência.

Nesse sentido, é preciso um novo olhar para as medidas socioeducativas, em razão da absoluta ineficácia do modelo atual. Dessa forma é proposta a Justiça Restaurativa. Ela representa, além da restauração do dano provocado ao ofendido e a reflexão do ofensor, uma forma da sociedade refletir e auxiliar no processo de restauração do adolescente, cuja exclusão é de sua coculpabilidade. 


\section{BIBLIOGRAFIA}

ALMEIDA, Ivy Gonçalves de; Rossetti-ferreira, Maria Clotilde; Serrano, Solange Aparecida. O acolhimento Institucional na Perspectiva da Criança. $408 \mathrm{p}$

AMARO, Sarita. Crianças vítimas da violência: das sombras do sofrimento à genealogia da resistência. Uma nova teoria científica. Porto Alegre: AGE/EDIPURS, 2003.

AZEVEDO E GUERRA apud AMARO, Sarita. Crianças vítimas da violência: das sombras do sofrimento à genealogia da resistência. Uma nova teoria científica. Porto Alegre: AGE/EDIPURS, 2003.

Alves R. Conversas com quem gosta de ensinar. São Paulo: Ars Poética, 1995.

BATISTA, Nilo. Introdução crítica ao direito penal brasileiro. 8. ed. Rio de Janeiro: Revan, p. 135.

BOULDING E 1981. Las Mujeres y la Violencia. In La Violencia y Sus Causas. p 265-279. Editorial UNESCO. Paris - França.

BRASIL. Ministério da Saúde. Violência faz mal à saúde. Brasília: Ministério da Saúde, 2004. 296 p.

BRASIL. Ministério da Saúde. Violência faz mal à saúde. Brasília: Ministério da Saúde, 2004. 296 p

CANOTILHO, José Joaquim Gomes. Direito constitucional e teoria da constituição. 3. ed. Coimbra: Almedina, 1999.

CAPEZ, Curso de Direito Penal-Legislação Penal Especial.p.

Conselho Nacional do Ministério Público. Um Olhar mais Atento aos Serviços de Acolhimento de Crianças e Adolescentes no País. Relatório da Resolução $n^{\circ} 71 / 2011$.

FOUCAULT, Michel. Vigiar e punir: nascimento da prisão. Tradução de Raquel Ramalhete. 35. ed. Petrópolis: Vozes, 2008. 
FRANCO, Alberto Silva. Leis Penais Especiais e sua Interpretação Jurisprudencial. São Paulo: RT, 2002, v.II.

GOMES DA COSTA, Antonio Carlos. O Estatuto da criança e do adolescente e o trabalho infantil no Brasil: trajetória, situação atual e perspectivas. Imprenta: São Paulo, Ltr, 1994.

WEBER, Max. A Ética Protestante e o Espírito do Capitalismo. São Paulo: Editora Martin Claret, 2002.

GRECO, Rogério. Curso de direito penal: parte geral. 2. ed. Rio de Janeiro: Impetus, 2002.

BRANCHER, Leoberto, TODESCHINI, Tânia Benedetto, MACHADO, Cláudia(sistematização e redação). Guia de procedimento Restaurativo implementado em porto Alegre e presente em JUSTIÇA PARA O SÉCULO 21: Instituindo Práticas Restaurativas: Manual de práticas Restaurativas/Compilação. - Porto Alegre, RS: AJURIS, 2008.

JUNQUEIRA, Gustavo Octaviano. Legislação Penal Especial volume 2, 3. Ed.-São Paulo: Saraiva 2010. P. 593-619.

MNMMR (1995). 10 anos de Movimento Nacional de Meninos e Meninas de Rua. UNICEF. Out. (Disponível no Movimento Nacional de Meninos e Meninas de Rua.)

NOGUEIRA FILHO,Paulo. S.A.M., Sangue Corrução e Vergonha. São Paulo: Revista dos Tribunais, 1956. 391 p.

5 PEREIRA, Tânia da Silva. Direito da criança e do adolescente: Uma proposta interdisciplinar. 2. ed. rev. e atual. Rio de Janeiro: Renovar, 2008. Nota Pública da Coordenadoria de defesa dos direitos da criança e do adolescente sobre a Central de Recepção de Crianças e Adolescentes Taiguara.

NUCCI, Guilherme de Souza. Leis Penais e Processuais Penais Comentadas. $6^{\text {a }}$.ed,ver.atual. e ref. -São Paulo: Editora Revista dos Tribunais, 2012. P. 683-685.

PIOVESAN, Flávia. Direitos humanos e o Direito Constitucional Internacional. 5a . ed. São Paulo: Max Limonad, 2002. 
Política Nacional de Assistência Social PNAS/ 2004, Brasília, Novembro 2005 e Relatório de visitas aos "ABRIGOS ESPECIALIZADOS" para crianças e adolescentes, junho de 2012,p. 11.

REALE JÚNIOR, Miguel. 1944- Instituições de direito penal. Rio de Janeiro: Forense, 2004. p.344.

Relatório social arrolado aos autos do processo 0059985-67.2015.8.19.000. Resolução CNAS n 109 de novembro de 2009.

ROURE, G. (1996). Vidas silenciadas: A violência com crianças $e$ adolescentes. Campinas, SP: UNICAMP.

SANDERSON, C. (2005). Abuso sexual em crianças. São Paulo: M. Brooks do Brasil. [ [ Links ]

SANTOS, Milton. Espaço e método. São Paulo: Nobel, 1985, pag.71

SARLET, Ingo. Dimensões da Dignidade. Porto Alegre: Livraria do Advogado, 2005.

VOLPI, M. Sem Liberdade, Sem Direitos: a privação da liberdade na percepção do adolescente. SP: Cortez, 2001.

WAISELFISZ, Julio Jacobo Julio Jacobo. Mapa da Violência 2012. Crianças e Adolescentes do Brasil, págs 62 a 83.

WALGRAVE, L., 1993. Au-delà de la rétribution et de la réhabilitation : la réparation comme paradigme dominant dans l'intervention judiciaire contre la délinquance des jeunes? in J. F. Gazeau e V. Peyre, eds., La justice réparatrice et les jeunes (Vaucresson, 9ièmes journée internationales de criminologie juvenile): pp. 5-28.

Zaffaroni, Eugenio Raul. Manual de direito penal brasileiro: volume 1: parte geral In Eugenio Raúl Zafarroni, José Henrique Pierangeli.- 9. Ed. Ver. E atual.- São Paulo: Editora Revista dos Tribunais, 2011. 768p 
Sites:

http://www.equalrightstrust.org/ertdocumentbank/err9_mulheir.pdf

http://www.guilhermenucci.com.br/artigos/guilherme-nucci/eca/lei-da-

palmada-outra-demagogia-2

http://www.ipea.gov.br/portal/images/stories/PDFs/nota_tecnica/140327_no

tatecnicadiest11.pdf, página 7.

http://www.mariaberenice.com.br/uploads/lei_da_palmada.pdf

http://www.premioinnovare.com.br/praticas/projeto-violeta-

20140527232412433005 
Anexo 4

Foto 1- Instituição de acolhimento Casa da Criança

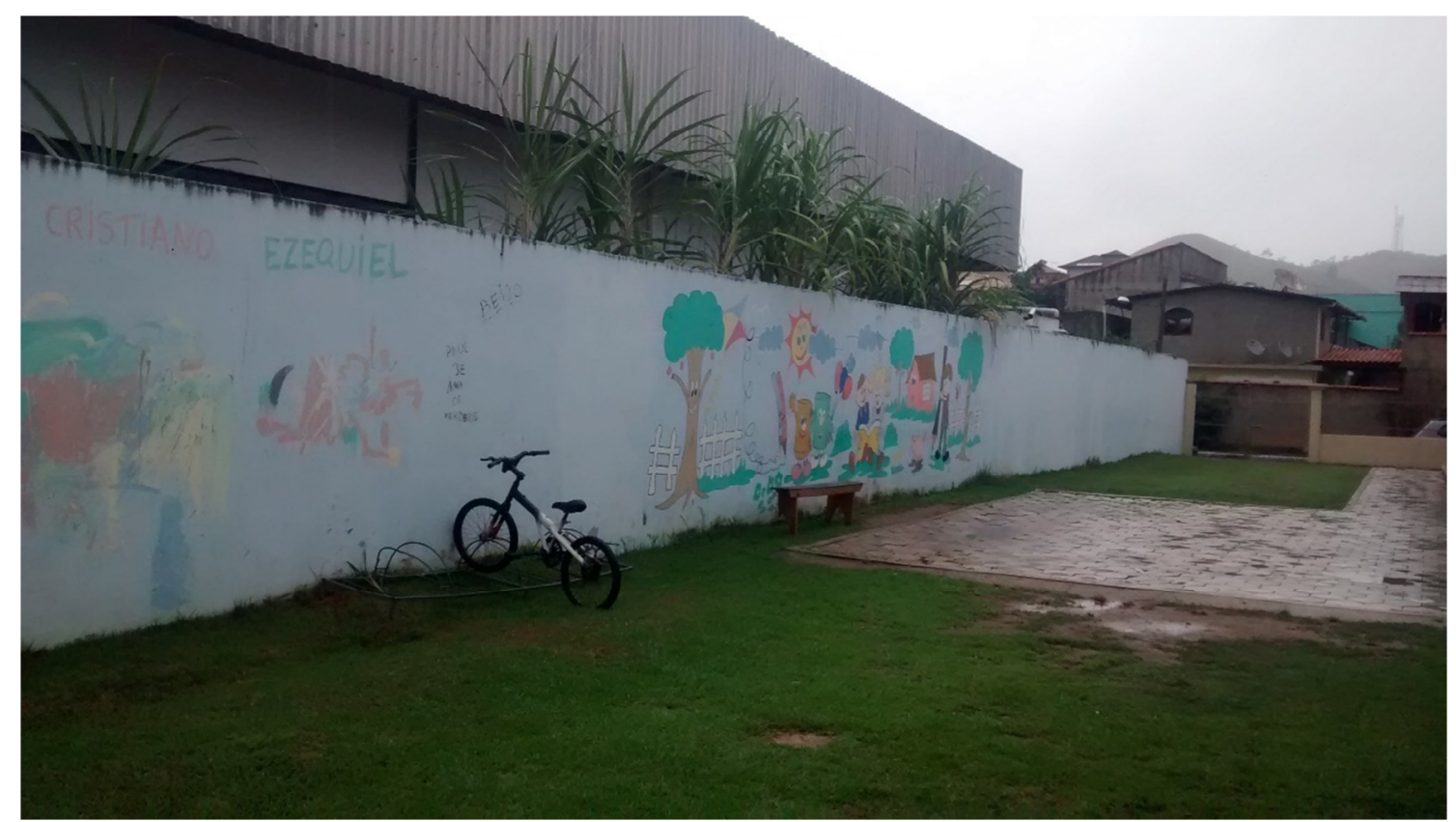

Foto 2- Unidade de internação Educandário Santo Expedito

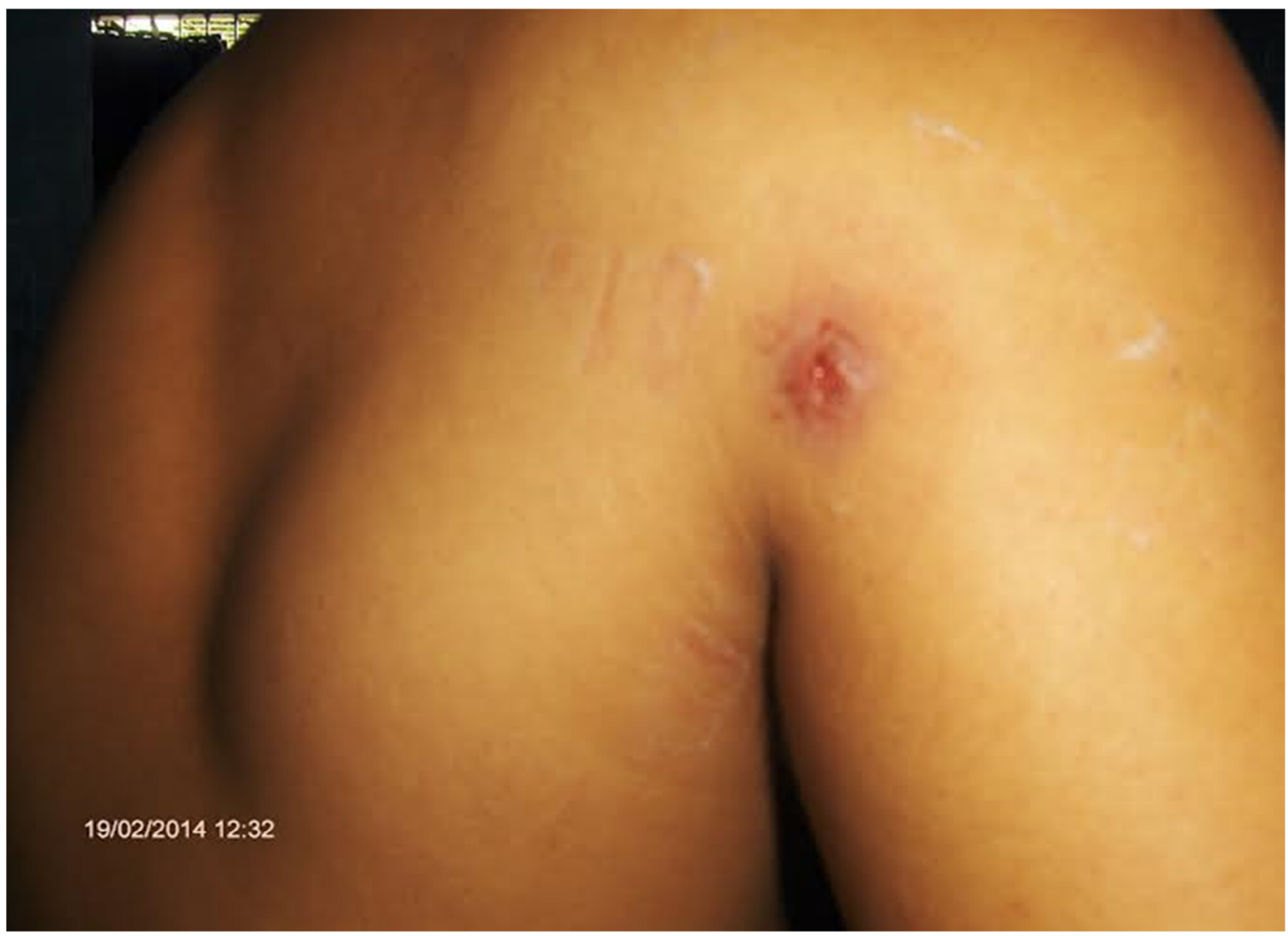


Foto 3- Unidade de internação Educandário Santo Expedito

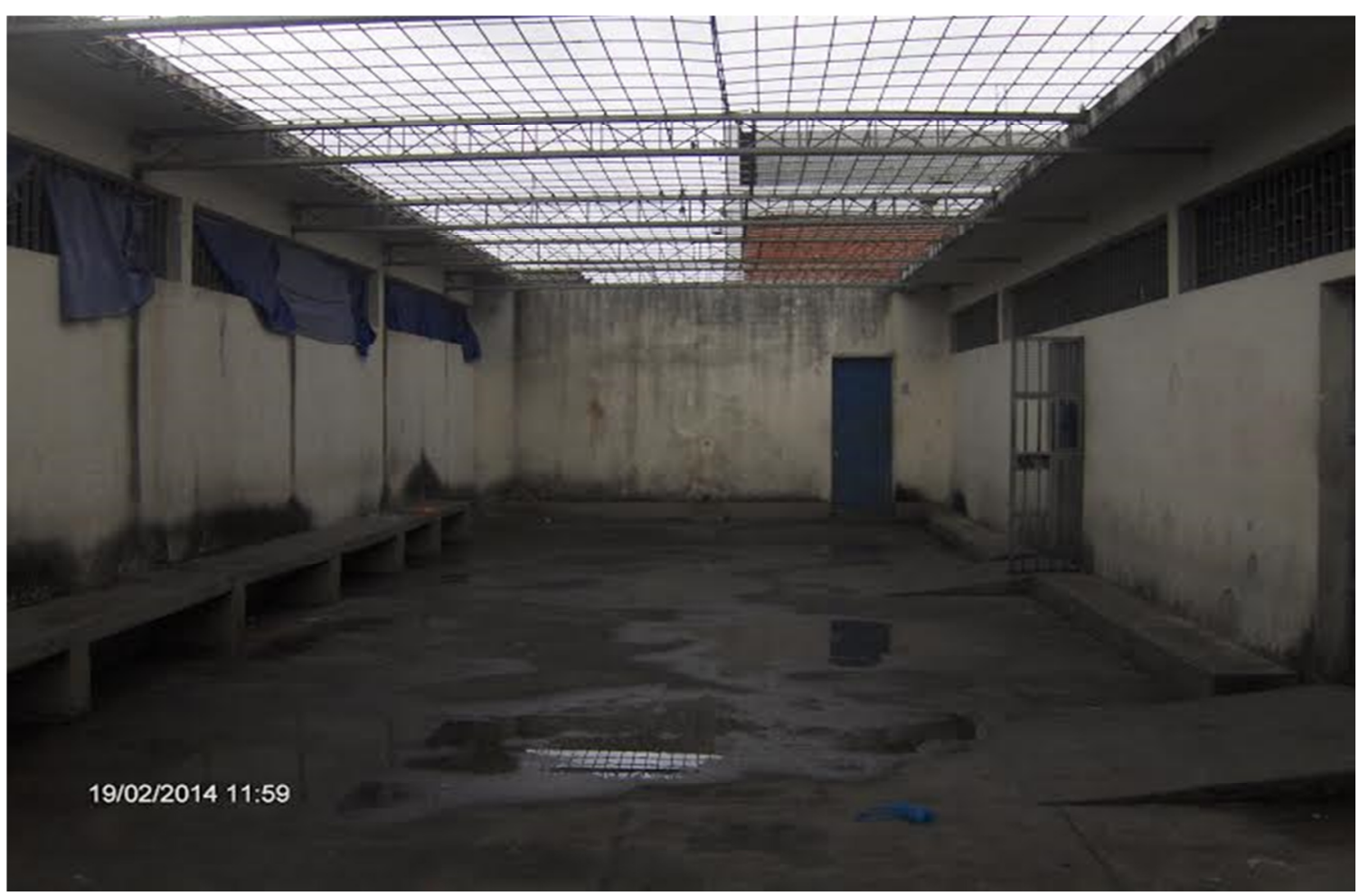

Foto 4- Unidade de internação Educandário Santo Expedito

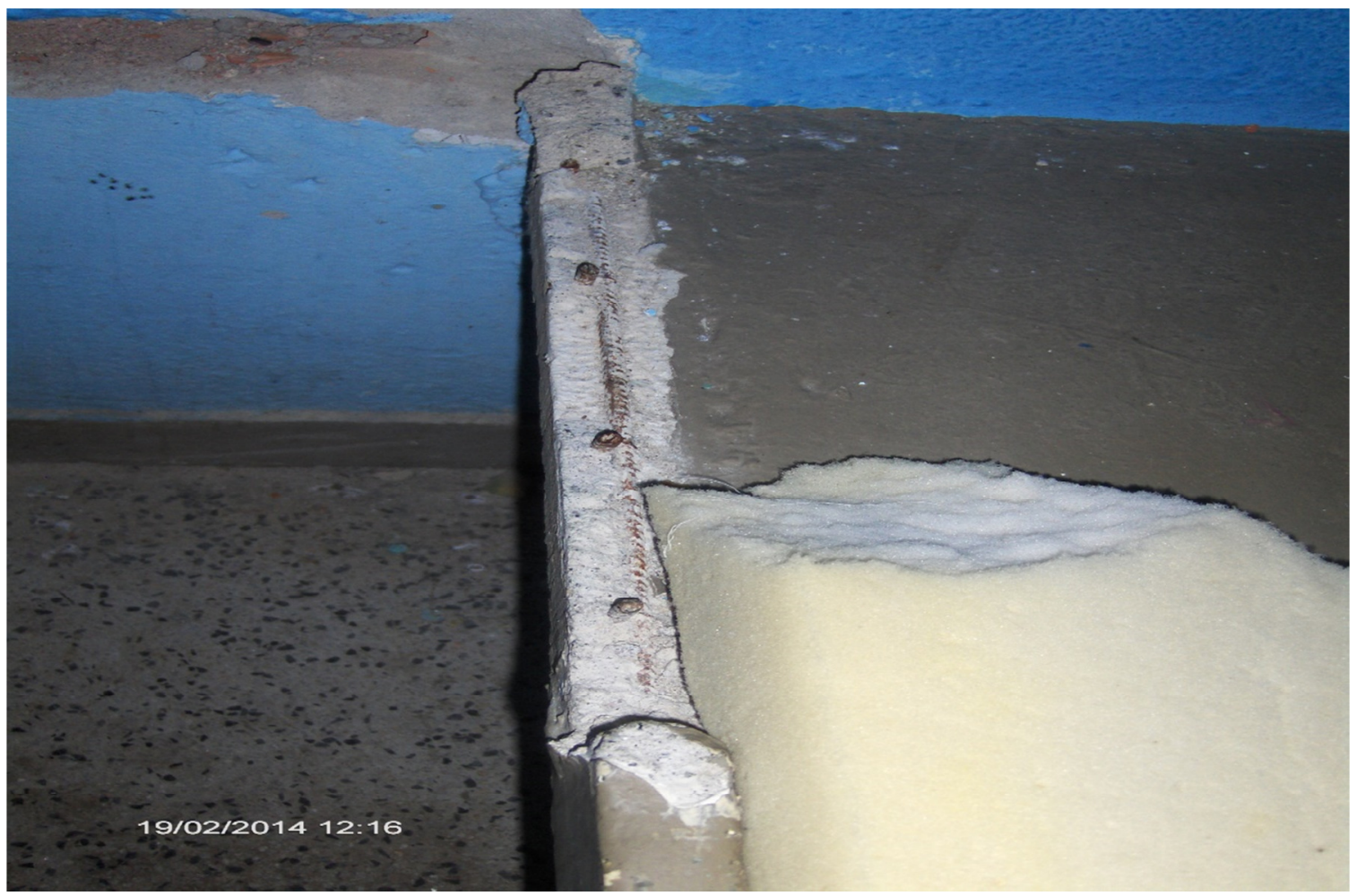


Foto 5- Unidade de internação Santo Expedito

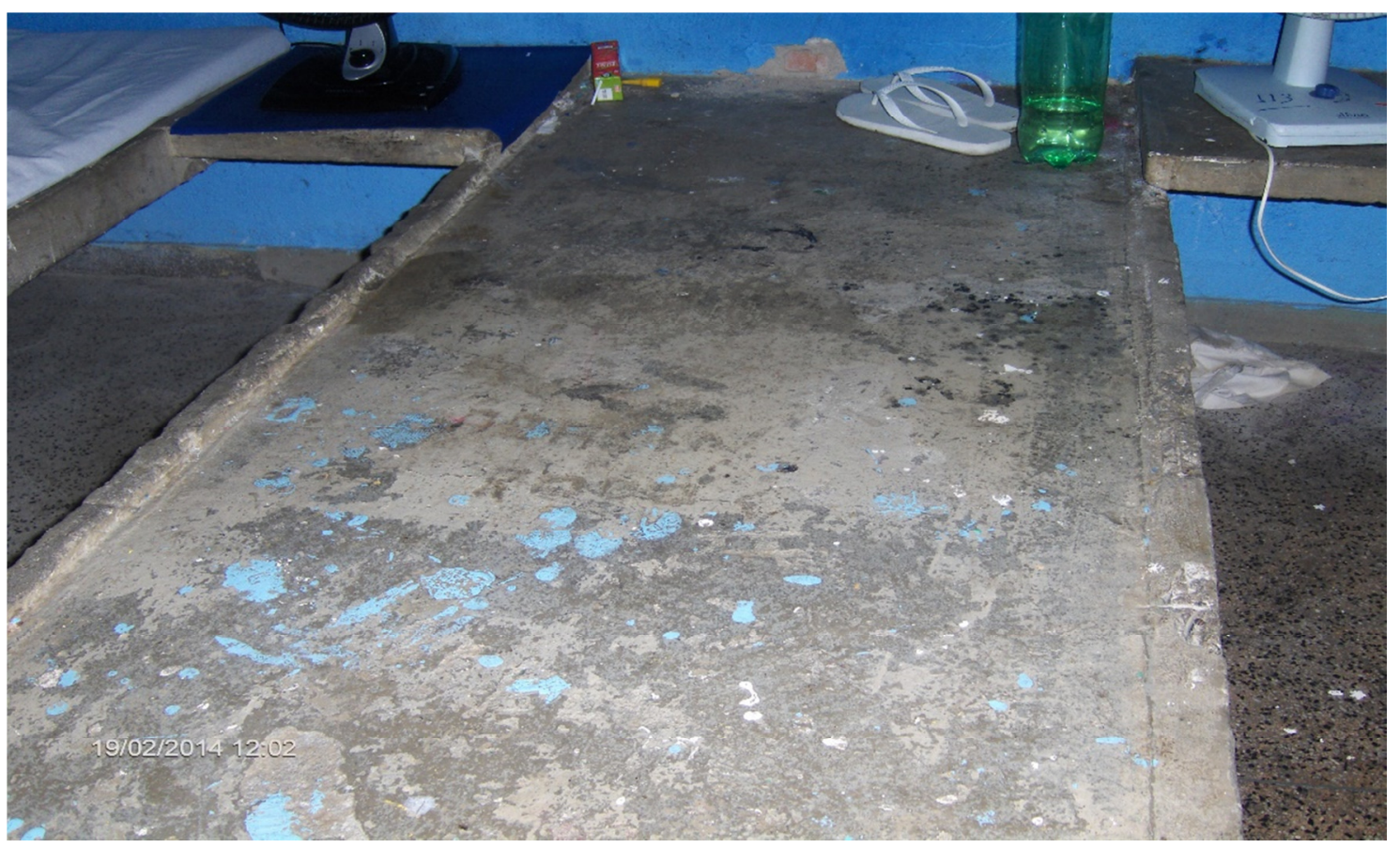

Foto 6- Central de triagem Taiguara (atualmente)

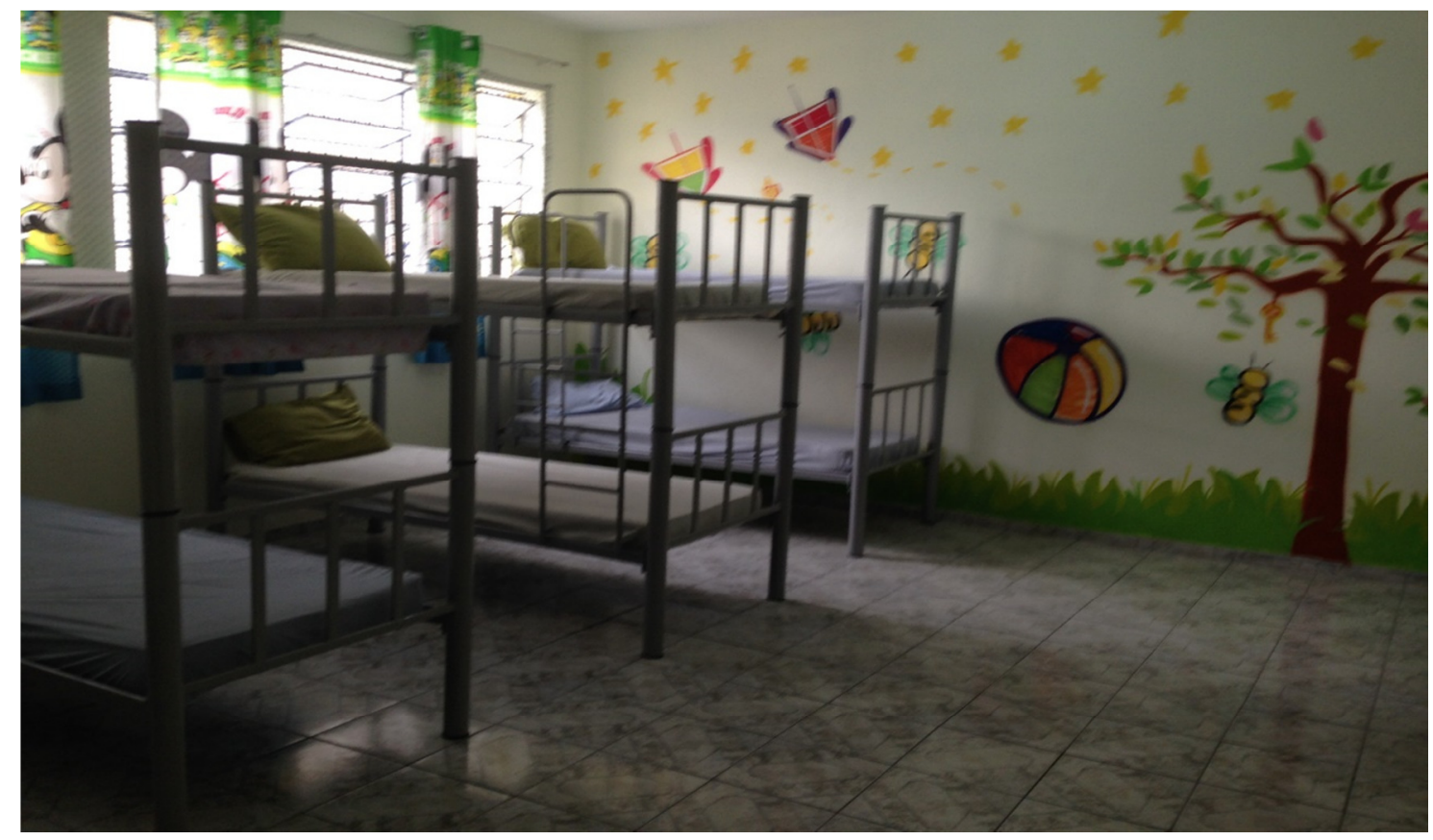


Foto 7- Central de Acolhimento Ayrton Sena

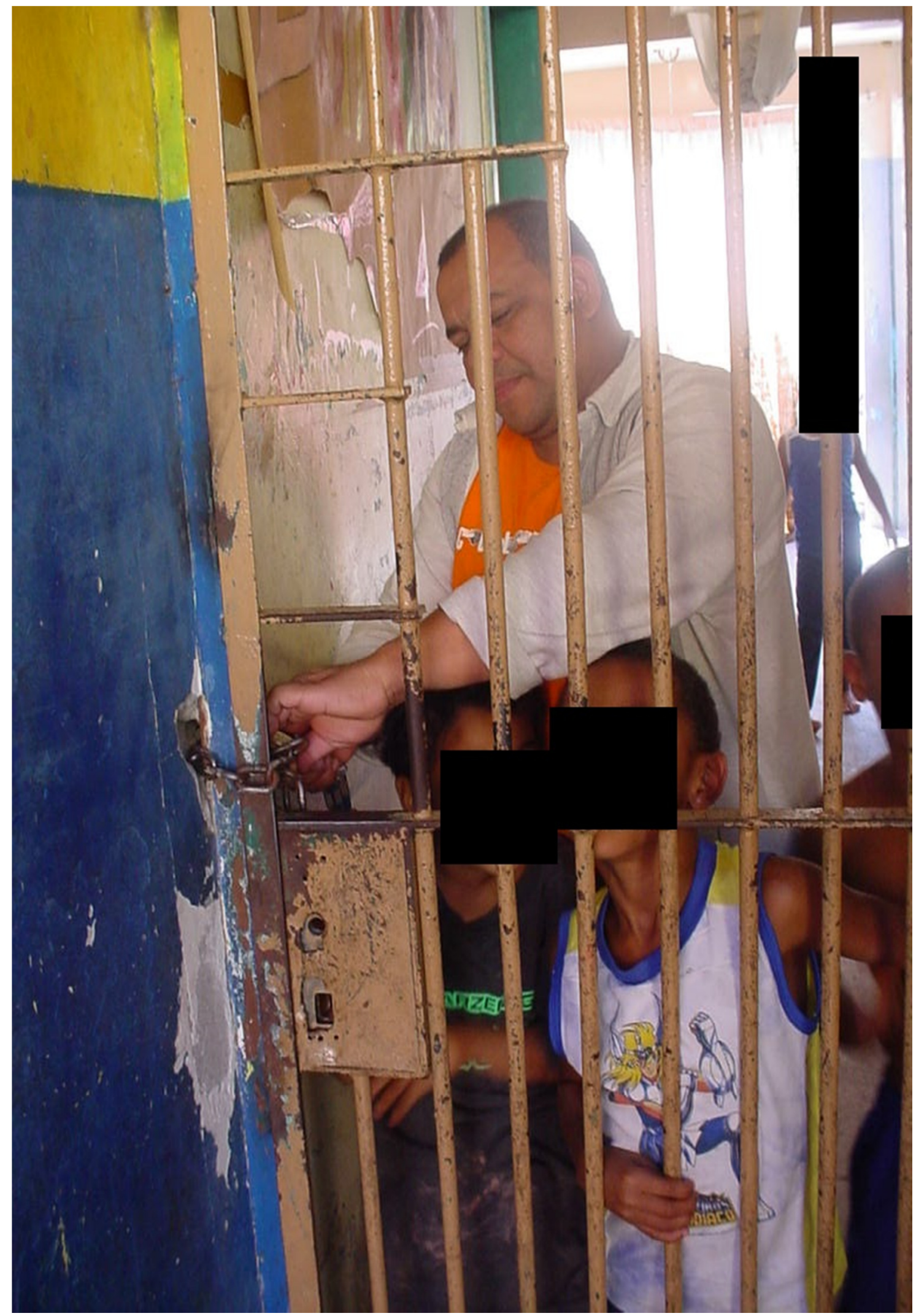


Foto 8- Central de acolhimento Ayrton Sena

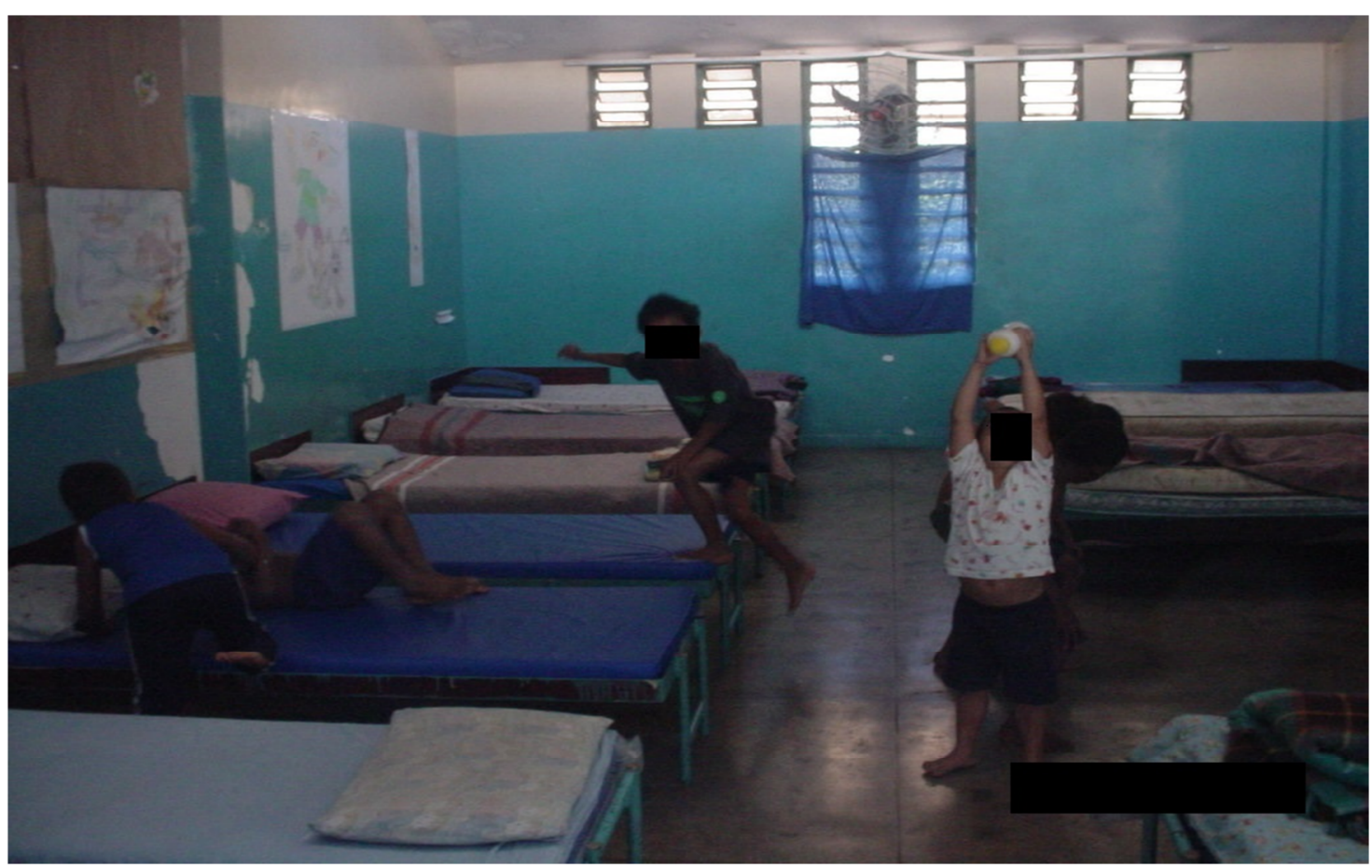

Foto 9- Central de acolhimento Ayrton Sena

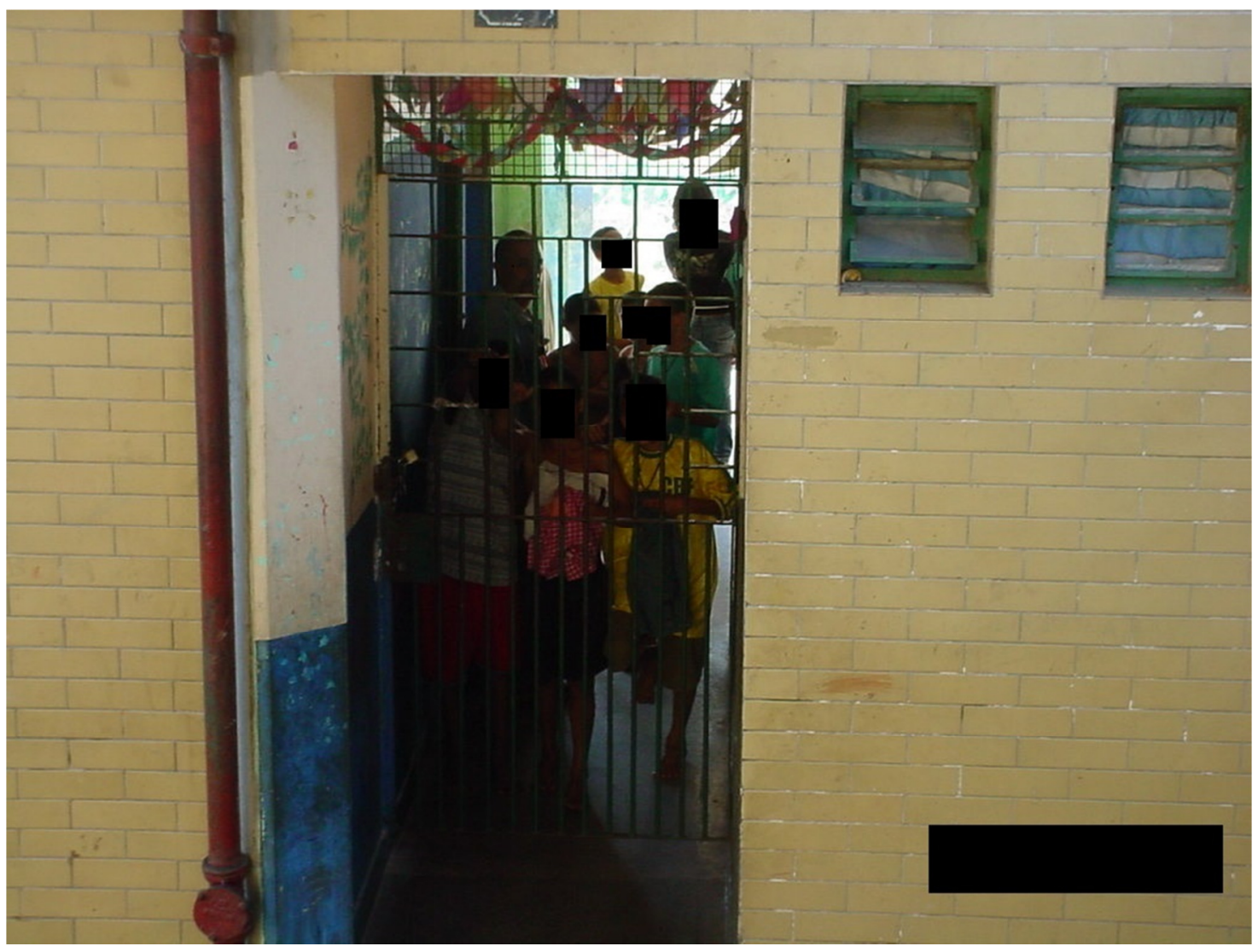

